Prepared in cooperation with the Coachella Valley Water District

\title{
Land Subsidence, Groundwater Levels, and Geology in the Coachella Valley, California, 1993-2010
}

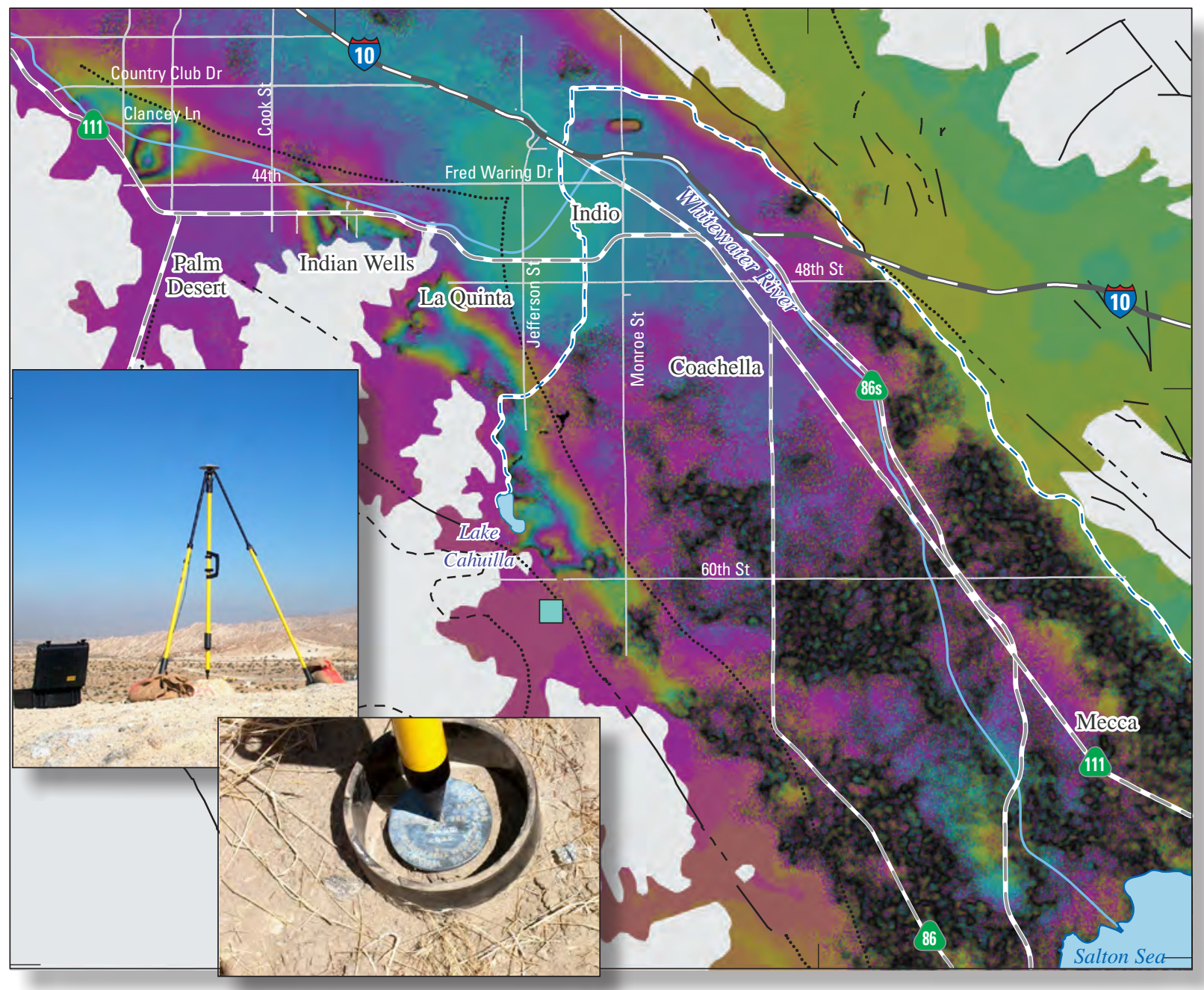

Scientific Investigations Report 2014-5075 
Cover. InSAR interferogram of the Coachella Valley, California. Upper left: Global Positioning System equipment collecting three-dimensional position data at a geodetic monument. Lower left: Geodetic monument with the tip of a fixed-height tripod on the measuring point. 


\section{Land Subsidence, Groundwater Levels, and Geology in the Coachella Valley, California, 1993-2010}

By Michelle Sneed, Justin T. Brandt, and Mike Solt

Prepared in cooperation with the Coachella Valley Water District

Scientific Investigations Report 2014-5075 


\title{
U.S. Department of the Interior SALLY JEWELL, Secretary
}

\section{U.S. Geological Survey Suzette M. Kimball, Acting Director}

\author{
U.S. Geological Survey, Reston, Virginia: 2014
}

For more information on the USGS - the Federal source for science about the Earth, its natural and living resources, natural hazards, and the environment, visit http://www.usgs.gov or call 1-888-ASK-USGS.

For an overview of USGS information products, including maps, imagery, and publications, visit http://www.usgs.gov/pubprod

To order this and other USGS information products, visit http://store.usgs.gov

Any use of trade, firm, or product names is for descriptive purposes only and does not imply endorsement by the U.S. Government.

Although this information product, for the most part, is in the public domain, it also may contain copyrighted materials as noted in the text. Permission to reproduce copyrighted items must be secured from the copyright owner.

Suggested citation:

Sneed, Michelle, Brandt, J.T., and Solt, Mike, 2014, Land subsidence, groundwater levels, and geology in the Coachella Valley, California, 1993-2010: U.S. Geological Survey, Scientific Investigations Report 2014-5075, 62 p. http://dx.doi.org/10.3133/sir20145075

ISSN 2328-0328 (online) 


\section{Contents}

Abstract

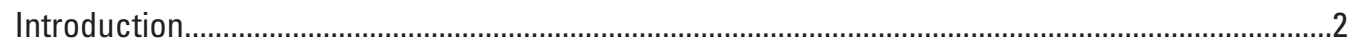

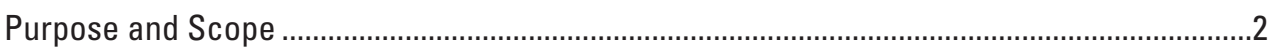

Description of Study Area .............................................................................................

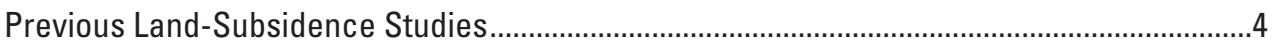

Tectonic and Hydrogeologic Setting ........................................................................................

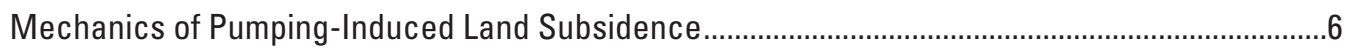

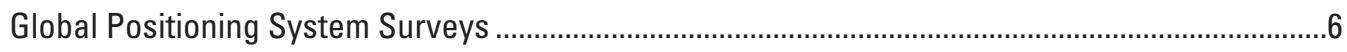

Land-Subsidence Monitoring Network ................................................................................

Determination of Ellipsoid Heights.......................................................................................

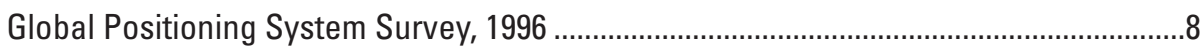

Global Positioning System Survey, 1998 ...........................................................................

Global Positioning System Survey, 2000 …………………………………….........

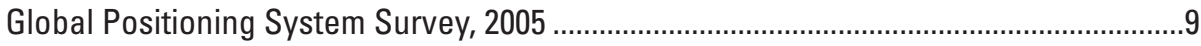

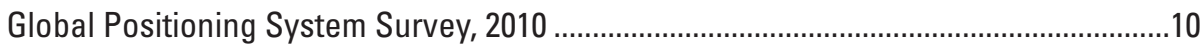

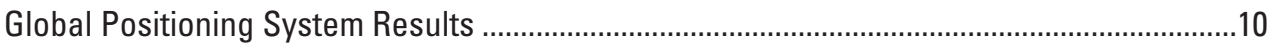

Groundwater Levels near Global Positioning System Stations ............................................18

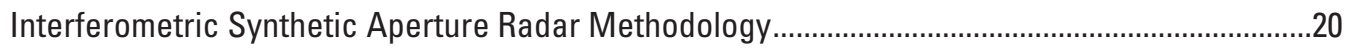

Interferometric Synthetic Aperture Radar Detection of Land Subsidence ...........................24

The Palm Desert Area (Area 1).......................................................................................24

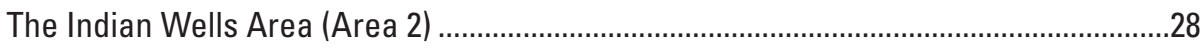

Land Subsidence near La Quinta, Including Parts of the Coachella Branch of the All-American Canal (Area 3) ...........................................................................30

Groundwater Levels near the Three Subsiding Areas Detected by Using Interferometric Synthetic Aperture Radar ..................................................................34

Comparison of Global Positioning System and Interferometric Synthetic Aperture

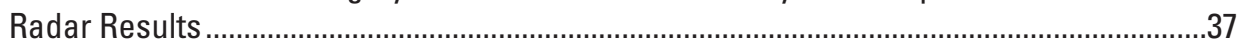

Comparison of Deformation Rates Derived from Global Positioning System-Survey and Interferometric Synthetic Aperture Radar Data....................................................37

Comparison of Deformation Magnitudes Derived from Continuous-Global Positioning System and Interferometric Synthetic Aperture Radar Data ......................................37

Correlation of Land Subsidence, Groundwater Levels, Geologic Structures, and

Fine-Grained Deposits ......................................................................................................39

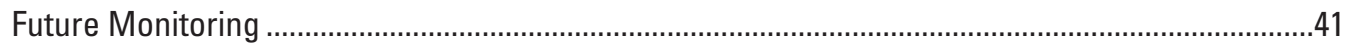

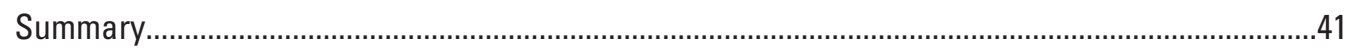

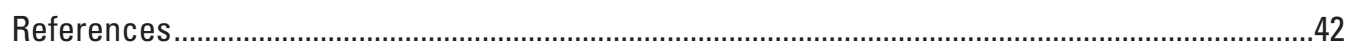

Appendix A. Persistent Scatterer Interferometric Synthetic Aperture Radar Interferograms,

Coachella Valley, California .................................................................................................... 


\section{Figures}

1. Map showing location of study area and of six Continuous Global Positioning System stations in or near Coachella Valley, California......

2. Map showing generalized geology of the Coachella Valley, California ...

3. Map showing network of Global Positioning System stations and wells used to monitor vertical changes in land surface and groundwater levels, respectively, in the southern Coachella Valley, California

4. Hydrographs showing water-surface elevations for selected wells between 1995 and 2010, and ellipsoid-height changes relative to the first measurement for the following geodetic monuments: $A$, DUNE; $B, \mathrm{COCH} ; C$, MAGF; $D$, MANI; $E$, OSDO; F, R70R; G, DEEP; $H$, 5211; I, 54JA/JA54; J, CAHU; $K$, S753; L, PAIN; $M$, C132; $N$, K572; O, JOHN; $P, \mathrm{C} 101 ;$ Q K K70; $R$, P572; S, SWC; T, G70; and, U, C427.

5. Graphs showing water-surface elevations, 1925-2010, for wells in $A$, the northern and central parts of the subsidence monitoring network; and $B$, the southern part of the subsidence monitoring network

6. Graph showing water deliveries to the Thomas E. Levy Recharge Facility for 2008-10

7. InSAR amplitude image showing land-surface features, consolidated rock, Global Positioning System stations, two Continuous Global Positioning System stations, three areas of subsidence, and selected roads and wells, Coachella Valley, California

8. Maps showing areas of subsidence, consolidated rock, Global Positioning System (GPS) stations, and two Continuous GPS stations in the Coachella Valley, California, for $A$, June 27, 1995-September 19, 2010, as shown on a stacked and kriged interferogram; and $B$, June 1, 2008-March 8, 2009, as shown on a conventional interferogram (black areas indicate incoherent InSAR data).

9. Maps showing the Palm Desert subsidence area (Area 1), Coachella Valley, California, showing one Global Positioning System station, one Continuous Global Positioning System station, consolidated rock, and selected roads and wells overlain on $A$, an amplitude image showing land-surface features; $B$, a stacked and kriged interferogram depicting subsidence during June 27, 1995-September 19, 2010; and $C$, a conventional interferogram depicting subsidence during June 1, 2008March 8, 2009

10. Graphs showing land subsidence in the Palm Desert area (Area 1), Coachella Valley, California, during June 27, 1995-September 19, 2010: A, time series for the location of maximum subsidence; and $B$, profile along Monterey Avenue...

11. Maps showing the Indian Wells subsidence area (Area 2), Coachella Valley, California, showing two Global Positioning System stations, consolidated rock, and selected roads and wells overlain on $A$, an amplitude image showing land-surface features; $B$, a stacked and kriged interferogram depicting subsidence during June 27, 1995-September 19, 2010; and $C$, a conventional interferogram depicting subsidence during June 1, 2008-March 8, 2009.

12. Graphs showing subsidence in the Indian Wells area (Area 2), Coachella Valley, California, during June 27, 1995-September 19, 2010, derived from interferograms shown in appendix $A$ : $A$, time series for three locations of maxima; and $B$, profile along Highway 111 


\section{Figures-Continued}

13. Maps showing the La Quinta subsidence area (Area 3), Coachella Valley, California, showing six Global Positioning System stations, consolidated rock, and selected roads and wells overlain on $A$, an amplitude image showing land-surface features; $B$, a stacked and kriged interferogram depicting subsidence during June 27, 1995September 19, 2010 (excluding November 8, 2000 and November 30, 2003) and subsidence time series for five selected locations; and $C$, a conventional interferogram depicting subsidence during June 1, 2008-March 8, 2009

14. Graphs showing subsidence in the La Quinta subsidence area (Area 3), Coachella Valley, California, during June 27, 1995-September 19, 2010, derived from interferograms shown in appendix $A$ (including estimated subsidence for November 8, 2000-November 30, 2003): $A$, time series for five selected locations (four are maxima) during June 27, 1995-September 19, 2010; and $B$, profile along Avenue 52.

15. Maps showing location of subsidence profile and selected locations along the Coachella branch of the All-American Canal, and graph showing subsidence magnitudes along the canal profile derived from selected interferograms shown in appendix $A$.

16. Hydrographs showing water-surface elevations for selected wells and Interferometric Synthetic Aperture Radar time series showing land subsidence for June 27, 1995-September 19, 2010, $A$, within the Palm Desert area of subsidence and Palm Desert, respectively; $B$, outside the Palm Desert area of subsidence and Palm Desert, respectively; $C$, within the Indian Wells area of subsidence and in the west, east, and third bowls; $D$, outside the Indian Wells area of subsidence and the west, east, and third bowls; and $E$, in the La Quinta area of subsidence and five locations in La Quinta.

17. Hydrographs showing water-surface elevations for selected wells in the Coachella Valley, California, $A$, for 1966-2010 within the Palm Desert area of subsidence; $B$, for 1971-2010 outside the Palm Desert area of subsidence; C, for 1979-2010 within the Indian Wells area of subsidence; $D$, for 1960-2010 outside the Indian Wells area of subsidence; and E, 1981-2010 within the La Quinta area of subsidence.

18. Graphs showing vertical displacements measured by Continuous Global Positioning System (CGPS) and by Interferometric Synthetic Aperture Radar at CGPS stations, $A$, COTD, and $B$, TMAP

19. Stratigraphic columns showing lithology, $A$, within the Palm Desert subsidence area and southwest of an inferred fault; $B$, within the Indian Wells subsidence area and southwest of an inferred fault; $C$, outside of the Palm Desert subsidence area and northeast of an inferred fault; $D$, within the La Quinta subsidence area; and $E$, near the margin of the La Quinta subsidence area 


\section{Tables}

1. Horizontal positions and ellipsoid heights of selected geodetic monuments in the Coachella Valley, California, for 1996, 1998, 2000, 2005, and 2010, and ellipsoid-height changes relative to the first measurement and for 1996-2010 and for 2005-10

2. Interferograms interpreted for this report

\section{Conversion Factors}

SI to Inch/Pound

\begin{tabular}{lcl}
\hline \multicolumn{1}{c}{ Multiply } & By & \multicolumn{1}{c}{ To obtain } \\
\hline centimeter $(\mathrm{cm})$ & Length & inch (in.) \\
millimeter $(\mathrm{mm})$ & 0.3937 & inch (in.) \\
meter $(\mathrm{m})$ & 0.03937 & foot (ft) \\
kilometer $(\mathrm{km})$ & 3.281 & mile (mi) \\
\hline & 0.6214 & acre \\
\hline square kilometer $\left(\mathrm{km}^{2}\right)$ & Area & square mile $\left(\mathrm{mi}^{2}\right)$ \\
square kilometer $\left(\mathrm{km}^{2}\right)$ & 247.1 & \\
\hline & 0.3861 & inch per year (in/yr) \\
\hline
\end{tabular}

Temperature in degrees Celsius $\left({ }^{\circ} \mathrm{C}\right)$ may be converted to degrees Fahrenheit $\left({ }^{\circ} \mathrm{F}\right)$ as follows:

${ }^{\circ} \mathrm{F}=\left(1.8 \mathrm{x}^{\circ} \mathrm{C}\right)+32$

Vertical displacements determined by InSAR and coordinates determined by Global Positioning System (GPS) surveying generally are reported in metric units. The industry standard for GPS usage is that field measurements and subsequently computations, including standard error determinations, are done in the metric system. The use of dual units in this report is intended to facilitate application of the data by maintaining the integrity of the original units of measurement for GPS surveying.

Vertical coordinate information is referenced to the National Geodetic Vertical Datum of 1929 (NGVD 29).

Ellipsoid heights: In this report, Global Positioning System (GPS) measurements of horizontal coordinates and ellipsoid heights are based on the North American Datum of 1983 (NAD 83).

Elevation, as used in this report, refers to distance above the vertical datum. 


\section{Abbreviations and Acronyms}

$\begin{array}{ll}\text { Caltrans } & \text { California Department of Transportation } \\ \text { CGPS } & \text { Continuous Global Positioning System } \\ \text { CVWD } & \text { Coachella Valley Water District } \\ \text { ENVISAT } & \text { ENVIronmental SATellite } \\ \text { ERS1 } & \text { European Remote Sensing satellite 1 } \\ \text { ERS2 } & \text { European Remote Sensing satellite 2 } \\ \text { ESA } & \text { European Space Agency } \\ \text { GPS } & \text { Global Positioning System } \\ \text { IGS } & \text { International GPS Service } \\ \text { InSAR } & \text { Interferometric Synthetic Aperture Radar } \\ \text { NAVSTAR } & \text { Navigation Signal Timing and Ranging } \\ \text { PS } & \text { Persistent Scatterer } \\ \text { SAR } & \text { Synthetic Aperture Radar } \\ \text { SOPAC } & \text { Scripps Orbit and Permanent Array Center } \\ \text { USGS } & \text { United States Geological Survey }\end{array}$




\section{Well-Numbering System}

Wells are identified and numbered according to their location in the rectangular system for the subdivision of public lands. Identification consists of the township number, north or south; the range number, east or west; and the section number. Each section is divided into sixteen 40-acre tracts lettered consecutively (except I and 0 ), beginning with " $A$ " in the northeast corner of the section and progressing in a sinusoidal manner to " $R$ " in the southeast corner. Within the 40-acre tract, wells are sequentially numbered in the order they are inventoried. The final letter refers to the base line and meridian. In California, there are three base lines and meridians; Humboldt (H), Mount Diablo (M), and San Bernardino (S). All wells in the study area are referenced to the San Bernardino base line and meridian (S). Well numbers consist of 15 characters and follow the format 005S006E23K002S. In this report, well numbers are abbreviated and written 5S/6E-23K2. Wells in the same township and range are referred to only by their section designation, -23K2. The following diagram shows how the number for well $5 \mathrm{~S} / 6 \mathrm{E}-23 \mathrm{~K} 2$ is derived.

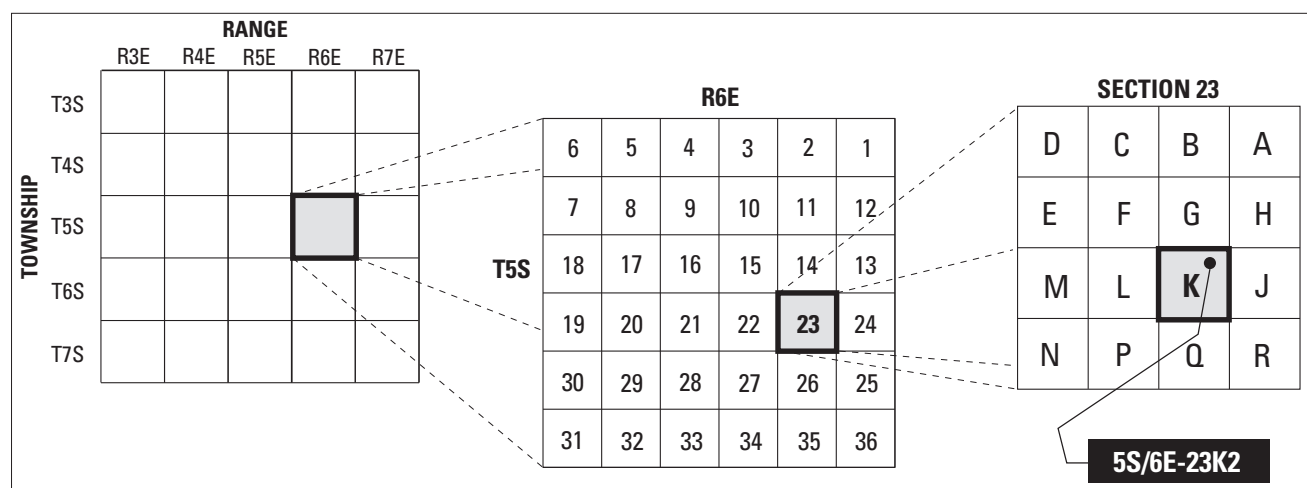

Well-numbering diagram (Note: maps in this report use abbreviated well numbers such as "23K2".)

\section{Acknowledgments}

The authors gratefully acknowledge the Coachella Valley Water District for their support and assistance during this study. We acknowledge the Scripps Orbit and Permanent Array Center for providing Global Positioning System data used in this study. We thank the University NAVSTAR Consortium for providing Global Positioning System equipment and exceptional technical support for the 2005 and 2010 Global Positioning System surveys. We thank the California Department of Transportation for providing fixed-height tripods for the 2005 and 2010 GPS surveys. Radar data used to produce the interferograms shown in this report were obtained from the European Space Agency for purposes of research and development. 


\title{
Land Subsidence, Groundwater Levels, and Geology in the Coachella Valley, California, 1993-2010
}

\author{
By Michelle Sneed, Justin T. Brandt, and Mike Solt
}

\section{Abstract}

L and subsidence associated with groundwater-level declines has been investigated by the U.S. Geological Survey in the Coachella Valley, California, since 1996. Groundwater has been a major source of agricultural, municipal, and domestic supply in the valley since the early 1920s. Pumping of groundwater resulted in water-level declines as much as 15 meters ( 50 feet) through the late 1940s. In 1949, the importation of Colorado River water to the southern Coachella Valley began, resulting in a reduction in groundwater pumping and a recovery of water levels during the 1950s through the 1970s. Since the late 1970s, demand for water in the valley has exceeded deliveries of imported surface water, resulting in increased pumping and associated groundwater-level declines and, consequently, an increase in the potential for land subsidence caused by aquifer-system compaction.

G lobal Positioning System (GPS) surveying and Interferometric Synthetic A perture Radar (InSA R) methods were used to determine the location, extent, and magnitude of the vertical land-surface changes in the southern Coachella Valley during 1993-2010. The GPS measurements taken at 11 geodetic monuments in 1996 and in 2010 in the southern Coachella Valley indicated that the elevation of the land surface changed -136 to -23 millimeters $(\mathrm{mm}) \pm 54 \mathrm{~mm}$ $(-0.45$ to -0.08 feet $(\mathrm{ft}) \pm 0.18 \mathrm{ft})$ during the 14 -year period. Changes at 6 of the 11 monuments exceeded the maximum expected uncertainty of $\pm 54 \mathrm{~mm}( \pm 0.18 \mathrm{ft}$ ) at the 95 -percent confidence level, indicating that subsidence occurred at these monuments between J une 1996 and A ugust 2010. GPS measurements taken at 17 geodetic monuments in 2005 and 2010 indicated that the elevation of the land surface changed -256 to $+16 \mathrm{~mm} \pm 28 \mathrm{~mm}(-0.84$ to $+0.05 \mathrm{ft} \pm 0.09 \mathrm{ft})$ during the 5 -year period. Changes at 5 of the 17 monuments exceeded the maximum expected uncertainty of $\pm 28 \mathrm{~mm}( \pm 0.09 \mathrm{ft})$ at the 95-percent confidence level, indicating that subsidence occurred at these monuments between A ugust 2005 and August 2010. At each of these five monuments, subsidence rates were about the same between 2005 and 2010 as between 2000 and 2005.
InSA R measurements taken between J une 27, 1995, and September 19, 2010, indicated that the land surface subsided from about 220 to $600 \mathrm{~mm}(0.72$ to $1.97 \mathrm{ft})$ in three areas of the Coachella Valley: near Palm Desert, Indian Wells, and La Q uinta. In Palm Desert, the average subsidence rates increased from about 39 millimeters per year $(\mathrm{mm} / \mathrm{yr})$, or 0.13 foot per year (ft/yr), during 1995-2000 to about $45 \mathrm{~mm} / \mathrm{yr}$ (0.15 ft/yr) during 2003-10. In Indian Wells, average subsidence rates for two subsidence maxima were fairly steady at about 34 and $26 \mathrm{~mm} / \mathrm{yr}(0.11$ and $0.09 \mathrm{ft} / \mathrm{yr}$ ) during both periods; for the third maxima, average subsidence rates increased from about 14 to $19 \mathrm{~mm} / \mathrm{yr}$ ( 0.05 to $0.06 \mathrm{ft} / \mathrm{yr}$ ) from the first to the second period. In La Quinta, average subsidence rates for five selected locations ranged from about 17 to $37 \mathrm{~mm} / \mathrm{yr}$ ( 0.06 to $0.12 \mathrm{ft} / \mathrm{yr}$ ) during 1995-2000; three of the locations had similar rates during 2003-mid-2009, while the other two locations had increased subsidence rates. Decreased subsidence rates were calculated throughout the L a Quinta subsidence area during mid-2009-10, however, and uplift was observed during 2010 near the southern extent of this area.

Water-level measurements taken at wells near the subsiding monuments and in the three subsiding areas shown by InSAR generally indicated that the water levels fluctuated seasonally and declined annually from the early 1990s, or earlier, to 2010; some water levels in 2010 were at the lowest levels in their recorded histories. A n exception to annually declining water levels in and near subsiding areas was observed beginning in mid-2009 in the L a Quinta subsidence area, where recovering water levels coincided with increased recharge operations at the Thomas E. L evy Recharge Facility; decreased pumpage also could cause groundwater levels to recover. Subsidence concomitant with declining water levels and land-surface uplift concomitant with recovering water levels indicate that aquifer-system compaction could be causing subsidence. If the stresses imposed by the historically lowest water levels exceeded the preconsolidation stress, the aquifer-system compaction and associated land subsidence could be permanent. 


\section{Introduction}

Groundwater has been a major source of agricultural, municipal, and domestic water supply in Coachella Valley, California (fig. 1), since the early 1920s. Pumping of groundwater resulted in water-level declines as much as 15 meters $(\mathrm{m})$, or 50 feet ( $\mathrm{ft}$ ), between the early $1920 \mathrm{~s}$ and late 1940s. In 1949, the importation of Colorado River water through the Coachella Canal, a branch of the All-A merican Canal, to the southern Coachella Valley began. As a result of the importation of surface water, pumping of groundwater decreased in the southern Coachella Valley during the 1950s through the 1970s, and water levels in some wells in the lower valley recovered as much as $15 \mathrm{~m}$ (50 ft). Since the late 1970s, however, the demand for water in the southern Coachella Valley has exceeded the deliveries of imported surface water, pumping has increased, and water levels have again declined. By 2010, water levels in many wells in the southern Coachella Valley had declined 15-30 m (50-100 ft), and water levels in some wells were at their lowest recorded levels. The Coachella Valley Water District (CVWD) is currently involved in several agreements and projects including the Quantification Settl ement A greement, tiered-rate structures, aquifer-recharge projects, and conversion from groundwater to surface water resources for (primarily) golf course irrigation through the M id-Valley Pipeline Project, that could reduce reliance on the groundwater resource (Coachella Valley Water District, 2012). Continued monitoring could track the effect these agreements and projects have on groundwater levels.

Declining water levels can contribute to or induce land subsidence in aquifer systems that consist of a substantial fraction of unconsolidated fine-grained sediments (silts and clays). I kehara and others (1997) reported as much as 150 millimeters $(\mathrm{mm}) \pm 90 \mathrm{~mm}(0.5 \mathrm{ft} \pm 0.3 \mathrm{ft})$ of subsidence in the southern parts of the Coachella Valley between 1930 and 1996. L and subsidence can disrupt surface drainage and watersupply or flood-control conveyances; cause earth fissures; and damage wells, buildings, roads, and utility infrastructure. A large earth fissure was discovered in 1948 about 3 kilometers $(\mathrm{km})$, or 2 miles (mi), north of Lake Cahuilla in La Quinta (unpublished field notes, Coachella Valley Water District, 1948). B ecause subsidence had not been documented in the southern parts of the Coachella Valley prior to the report by Ikehara and others (1997), it is not known if this fissure formed in response to differential land subsidence during the earlier period (early 1920s-late 1940s) of groundwater-level declines. However, fissuring has recurred in this area (Clay Stevens, TerraPacific Consultants, Inc., written commun., 2006). Subsidence-related earth fissures and reactivated surface faults have been identified in many other groundwater basins in the western U nited States (Holzer, 1984).

The CV W D works cooperatively with local stakeholders to manage the water supply for a large part of the Coachella Valley (fig. 1). B ecause of the potential for groundwater pumping to cause land subsidence, the CV W D entered into a cooperative agreement with the U.S. Geological Survey (USGS) to monitor vertical changes in land surface to determine if land was subsiding in the Coachella Valley. In 1996, the USGS established a geodetic network of monuments to monitor vertical changes in land surface in the southern Coachella Valley by using Global Positioning System (GPS) surveys and to establish baseline values for comparisons with results of future surveys. This geodetic network can be surveyed periodically to determine the distribution and amount of land subsidence. Interferometric Synthetic A perture Radar (InSA R) data collected since 1993 were used to detect and quantify land subsidence in areas distant from the geodetic monuments.

\section{Purpose and Scope}

The objectives of this study were to detect and quantify land subsidence in the southern Coachella Valley from 1993 through 2010 by completing GPS surveys at the established geodetic network of monuments and by using InSA R data. For purposes of this report, the southern Coachella Valley represents the southern half of the Coachella Valley, which extends from the communities of Palm Desert, Indian Wells, Indio, and La Quinta on the north to the Salton Sea on the south (fig. 1). This report presents the results and interpretations of GPS data collected at the monuments in the monitoring network during surveys in 1996, 1998, 2000, 2005, and 2010 and also of spatially detailed maps of vertical land-surface changes generated by using InSA R data collected between 1993 and 2010. The InSA R-generated maps extend from near Palm Desert to near the Salton Sea (fig. 1). Data showing groundwater-level changes from the early to mid1990s to 2010 were examined and compared with the GPS measurements and the InSA R-generated maps to determine if the vertical changes in land surface could be related to the changes in groundwater levels. 

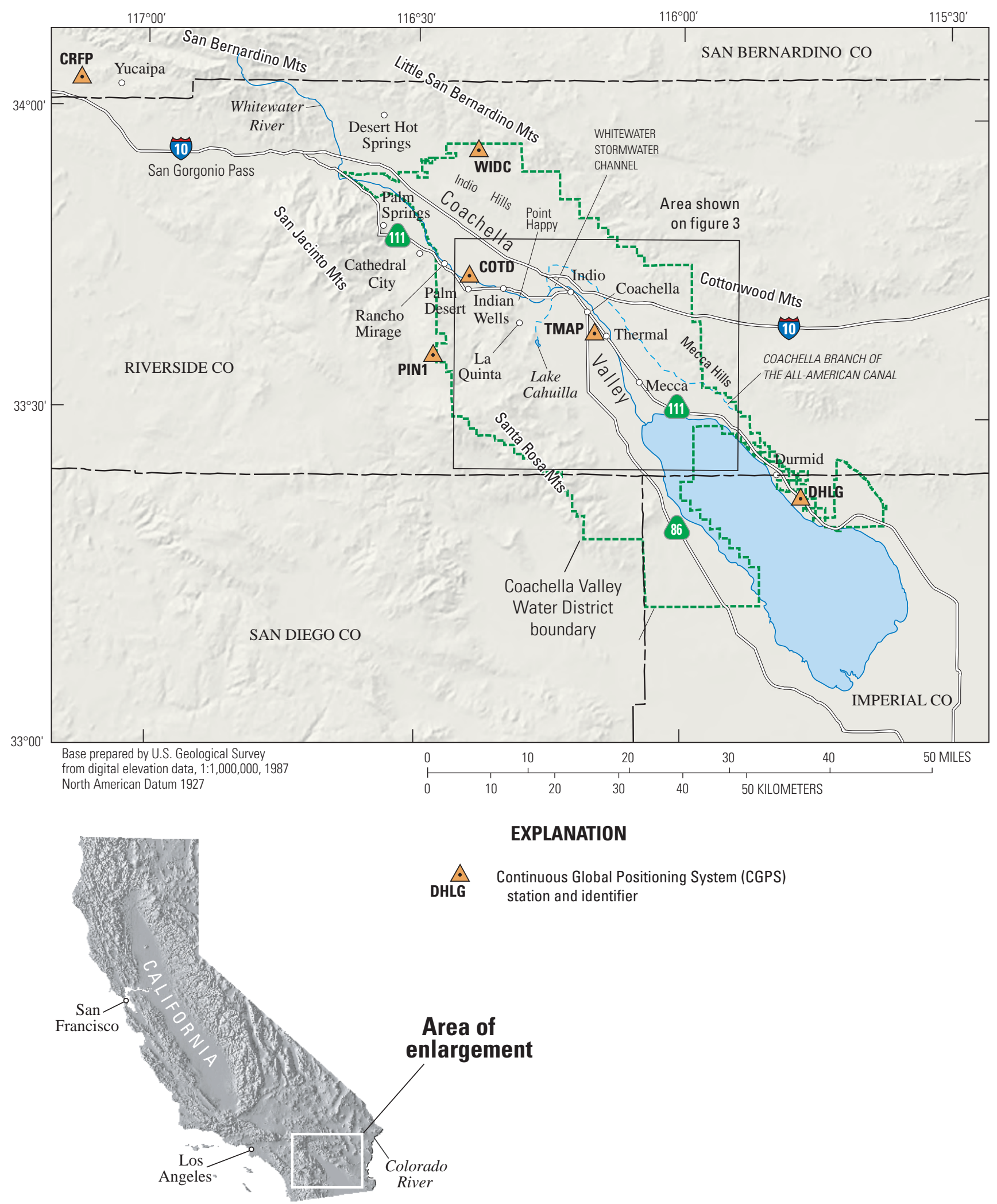

Figure 1. Location of study area and of six Continuous Global Positioning System (CGPS) stations in or near Coachella Valley, California. 


\section{Description of Study Area}

The Coachella Valley is a $100-\mathrm{km}$ (65-mi) long, northwest-trending valley in southeastern California (fig. 1). The valley covers about 1,000 square kilometers $\left(\mathrm{km}^{2}\right)$, or 400 square miles (mi2; California Department of Water Resources, 1964) and includes the cities of Cathedral City, Desert Hot Springs, Indio, La Quinta, Palm Desert, Palm Springs, and Rancho M irage, which are interspersed with about 125 golf courses. A griculture and smaller urban centers, such as Coachella, Thermal, and M ecca, are prominent in the southern part of the valley. The valley is bordered by the San J acinto and Santa Rosa M ountains on the west, the San B ernardino and the Little San B ernardino M ountains on the north, the Cottonwood M ountains and the M ecca Hills on the east, and the Salton Sea on the south (fig. 1). The Coachella Valley is drained primarily by the W hitewater River, which flows into the Whitewater Stormwater Channel and eventually discharges into the Salton Sea (fig. 1). Land-surface el evations vary from more than $70 \mathrm{~m}(230 \mathrm{ft})$ bel ow sea level at the Salton Sea to more than $3,000 \mathrm{~m}(10,000 \mathrm{ft})$ above sea level at the peaks of the surrounding mountains.

The climate of the Coachella Valley floor is arid. Average annual rainfall ranges from less than $80 \mathrm{~mm}$, or 3 inches (in), on the valley floor to more than $760 \mathrm{~mm}$ (30 in) on the crests of the mountains to the west and north of the valley (California Department of Water Resources, 1964). Temperatures range from about $50^{\circ} \mathrm{C}\left(122^{\circ} \mathrm{F}\right)$ on the valley floor in the summer to bel ow $0{ }^{\circ} \mathrm{C}\left(32^{\circ} \mathrm{F}\right)$ in the surrounding mountains in the winter.

\section{Previous Land-Subsidence Studies}

This study is the fifth in a series of Coachella Valley land-subsidence studies that have been completed by the USGS in cooperation with CV WD. Ikehara and others (1997) documented the development of the geodetic monitoring network and areas of possible land subsidence in Coachella Valley by comparing historical leveling measurements with GPS surveying measurements taken in 1996. The vertical changes in land surface between 1996 and the earliest historical leveling measurements at monuments in the monitoring network did not exceed $150 \mathrm{~mm}(0.5 \mathrm{ft}$; I kehara and others, 1997). The uncertainty ( $\pm 90 \mathrm{~mm}$ or $\pm 0.3 \mathrm{ft}$ ) of these calculated vertical changes in land surface is large because the historical leveling surveys were done at different times and, sometimes, by different agencies using different methods. Furthermore, the methods used for the leveling surveys had different accuracy standards, and the networks covered different geographic extents (I kehara and others, 1997). Sneed and others (2001) reported that GPS measurements indicated small amounts of subsidence between 1996 and 1998 at some monuments in the monitoring network. Sneed and others (2002) reported that GPS measurements indicated most monuments were fairly stable between 1998 and 2000, although subsequent GPS data processing indicated small amounts of subsidence at some monuments (Sneed and $B$ randt, 2007). Sneed and B randt (2007) reported that GPS measurements indicated that some monuments were fairly stable, while others subsided between 2000 and 2005. Sneed and others (2001, 2002) and Sneed and B randt (2007) also used InSA R to detect and quantify land subsidence throughout much of the Coachella Valley. InSA R measurements taken between 1996 and 2005 indicated as much as $330 \mathrm{~mm}$ (1.08 ft) of land subsidence in areas near Palm Desert, Indian Wells, and La Quinta (Sneed and others, 2001, 2002; Sneed and B randt, 2007).

\section{Tectonic and Hydrogeologic Setting}

The Coachella Valley is the northernmost extent of the Salton Trough, which is the landward extension of the spreading-ridge/transform-fault complex of the Gulf of California segment of the East Pacific Rise (Sylvester and Smith, 1976; Fuis and M ooney, 1990; M cK ibben, 1993). $\mathrm{N}$ ear the end of the $\mathrm{M}$ iocene, a spreading center separating the western Farallon plate from the eastern Pacific plate was obliquely subducted under the N orth A merican continent (A twater, 1970; M cK ibben, 1993). The modern Gulf of California and the Salton Trough formed about 12 million years ago, after subduction ceased, and when the formation of an inland belt of northwest to southeast crustal extension, alkali basalt volcanism, tectonic subsidence, and basin sedimentation began (A twater, 1970; M cK ibben, 1993). Prior to about 6 million years ago, the shear zone constituting the principal tectonic boundary between the Pacific and North A merican plates appears to have shifted about $250 \mathrm{~km}$ (155 $\mathrm{mi}$ ) inland into this belt, initiating the formation of the modern Gulf of California and the Salton Trough (A twater, 1970; M cK ibben, 1993). A s the Salton Trough opened, it was filled with sediment from the delta of the Colorado River. The river has been building its delta from the east, into the trough, since about 5 million years ago, and sedimentation has apparently kept pace with the tectonic subsidence (M cK ibben, 1993). The relation between tectonic subsidence, which is on a geologic time scale, and land subsidence, caused by groundwater-level declines measured during this study, is unknown in the study area, al though some efforts have been made to determine tectonically induced subsidence rates south of the study area ( $M$ eltzner and others, 2006; Crowell and others, 2013).

The Coachella Valley is filled with as much as $3,700 \mathrm{~m}$ $(12,000 \mathrm{ft})$ of sediments; the upper $610 \mathrm{~m}(2,000 \mathrm{ft})$ constitute the aquifer system that is the primary source of groundwater supply (California Department of Water Resources, 1979). The aquifer system consists of a complex unconsolidated to partly consolidated assemblage of gravel, sand, silt, and clay of alluvial and lacustrine origins (fig. 2). Sediments tend to be finer grained (contain more silt and clay) in the southern part of the valley compared to the northern part because of the 
greater distance from sediment source areas in the north and because of lacustrine deposition in the ancient L ake Cahuilla. In the southern Coachella Valley, the aquifer system consists of a semiperched zone that is fairly persistent southeast of Indio, an upper aquifer, a confining layer, and a lower aquifer. The general direction of groundwater flow is southeastward toward the Salton Sea (California D epartment of Water Resources, 1964, 1979).

The near-surface semiperched zone overlies the upper aquifer southeast of Indio and consists of silts, clays, and fine sand. The semiperched zone is as much as $30 \mathrm{~m} \mathrm{(100} \mathrm{ft)}$ thick and generally is an effective barrier to deep percolation (California Department of Water Resources, 1964, 1979). The upper aquifer is present throughout the Coachella Valley and consists of unconsolidated and partly consolidated silty sands and gravels with interbeds of silt and clay. In general, the upper aquifer is $45-90 \mathrm{~m}$ (150-300 ft) thick. The aquifer is unconfined, except where it is overlain by the semiperched zone southeast of Indio. In the southern Coachella Valley, the upper aquifer is separated from the low er aquifer by a confining layer of silt and clay that is 30 to $60 \mathrm{~m}$ (100 to $200 \mathrm{ft}$ ) thick. The lower aquifer is the most productive source of groundwater in the southern Coachella Valley; it consists of unconsolidated and partly consolidated silty sands and gravels with interbeds of silt and clay. The top of the lower aquifer is about 90 to $180 \mathrm{~m}$ (300 to $600 \mathrm{ft}$ ) below land surface. Available data indicate that the lower aquifer is at least $150 \mathrm{~m}$ $(500 \mathrm{ft})$ thick and could be as much as $600 \mathrm{~m}(2,000 \mathrm{ft})$ thick (California Department of Water Resources, 1964, 1979).

\section{EXPLANATION}

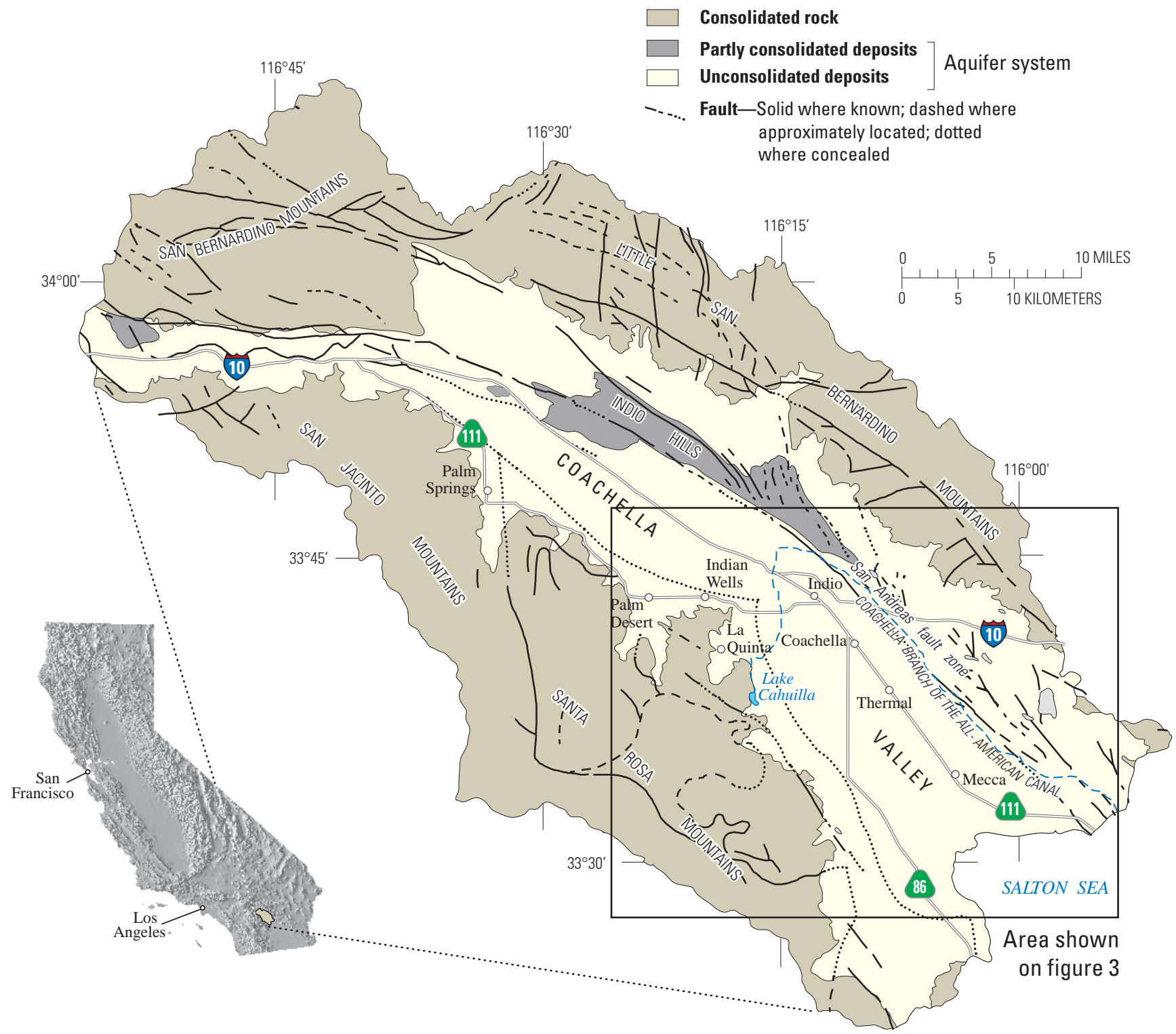

Figure 2. Generalized geology of the Coachella Valley, California. Figure modified from Tyley (1971). 
Geologic structures in the Coachella Valley have a marked influence on the occurrence and movement of groundwater. The principal structural features of Coachella Valley are faults and fault-related drag and compressional folds. The most notable fault system is the northwesttrending San Andreas fault zone that flanks the eastern side of the valley (fig. 2). Although movement within the San A ndreas fault zone is predominantly right lateral (across the fault, movement is to the right), vertical displacement has downdropped the southwest block (California D epartment of Water Resources, 1964). The faults may have either juxtaposed consolidated rocks against partly consolidated or unconsolidated water-bearing deposits or displaced preferential flow paths in the partly consolidated or unconsolidated water-bearing deposits. This juxtaposition and displacement, in conjunction with cementation, compaction, and extreme deformation of water-bearing deposits adjacent to faults, can create low-permeability zones that can act as barriers to groundwater flow.

\section{Mechanics of Pumping-Induced Land Subsidence}

L and can subside as a result of groundwater pumping in valleys containing aquifer systems that are, at least in part, made up of fine-grained sediments and that have undergone extensive groundwater development (Poland, 1984). The pore structure of a sedimentary aquifer system is supported by the granular skeleton of the aquifer system and the porefluid pressure of the groundwater that fills the intergranular pore space (M einzer, 1928). W hen groundwater is withdrawn in quantities that result in reduced pore-fluid pressures and in water-level declines, the reduction of the pore-fluid pressure support increases the intergranular stress, or effective stress, on the skel eton. A change in effective stress deforms the skel eton: an increase in effective stress compresses it, and a decrease in effective stress causes it to expand. This deformation is sometimes inelastic (non-recoverable), resulting in vertical compaction of the aquifer system, a permanent reduction in aquifer-system storage capacity, and land subsidence. A $n$ aquifer-system skeleton that primarily consists of fine-grained sediments, such as silt and clay, is much more compressible than one that primarily consists of coarse-grained sediments, such as sand and gravel. Inelastic compaction of coarse-grained sediment generally is negligible (I reland and others, 1984; Hanson, 1989; Sneed and Galloway, 2000).

A quifer-system deformation can be elastic (recoverable) if the effective stress imposed on the skel eton is less than any previous effective stress (Terzaghi, 1925). The greatest historical effective stress imposed on the aquifer systemsometimes the result of the lowest groundwater level-is the "preconsolidation stress," and the corresponding (lowest) groundwater level is the "preconsolidation head"
(Leake and Prudic, 1991). If the effective stress exceeds the preconsolidation stress, the pore structure of the granular matrix of the fine-grained sediments is rearranged; this new configuration results in a reduction of pore volume and, thus, inelastic compaction of the aquifer system. Furthermore, the compressibility of the fine-grained sediments constituting the aquitards, and any resulting compaction under stresses exceeding the preconsolidation stress, is 20 to more than 100 times greater than under stresses less than the preconsolidation stress (Riley, 1998).

This simple compaction model does not account for delayed drainage from low-permeability fine-grained sediments. For a developed aquifer system with an appreciable thickness of fine-grained sediments, a substantial part of the total compaction can be residual compaction (Sneed and Galloway, 2000). Residual compaction occurs in thick aquitards as heads in the thick aquitards equilibrate with heads in the surrounding aquifers (Terzaghi, 1925). Depending on the thickness and the vertical hydraulic diffusivity of a thick aquitard, fluid-pressure equilibration - and thus compaction-lags behind pressure (or hydraulic head) declines in the adjacent aquifers; concomitant compaction can require decades or centuries to approach completion. Thus, if the aquifer head declines bel ow the previous lowest level for a relatively short period, the preconsolidation head in the aquitard is not necessarily reset to the new low value (Phillips and others, 2003). For a more complete description of aquifersystem compaction, see Poland (1984); for a review on the history of the aquitard-drainage model, see Holzer (1998); and, for a review and selected case studies of land subsidence caused by aquifer-system compaction in the U nited States, see Galloway and others (1999).

\section{Global Positioning System Surveys}

GPS is a U.S. Department of D efense satel lite-based navigation system designed to provide continuous worldwide positioning and navigation capability. For this study, GPS surveys were conducted to determine the three-dimensional position of monuments in the geodetic monitoring network. This network was established in 1996 by the USGS to measure changes in land-surface el evations at the monuments relative to the results of future surveys (I kehara and others, 1997).

\section{Land-Subsidence Monitoring Network}

The geodetic monitoring network, henceforth referred to as the land-subsidence monitoring network, consists of geodetic monuments used as G PS stations (fig. 3). M ost geodetic monuments consist of flat metal disks that are anchored in the ground or to a structure and can be surveyed repeatedly. During the 1996 study by Ikehara and others (1997), historical data for monuments in the southern Coachella Valley were compiled and reviewed to determine 
the location and the quality of the vertical-control data.

Sources of the data include $\mathrm{N}$ ational $\mathrm{O}$ ceanic and $\mathrm{A}$ tmospheric A dministration's (NOA A) N ational Geodetic Survey (formerly the U.S. Coast and Geodetic Survey), the California Department of Transportation (Caltrans), the U.S. B ureau of
Reclamation, and the CVW D (I kehara and others, 1997). The geodetic monuments were examined before each of the GPS surveys in 1996, 1998, 2000, 2005, and 2010 to determine if any had been damaged or destroyed and to eval uate their suitability for GPS observations.

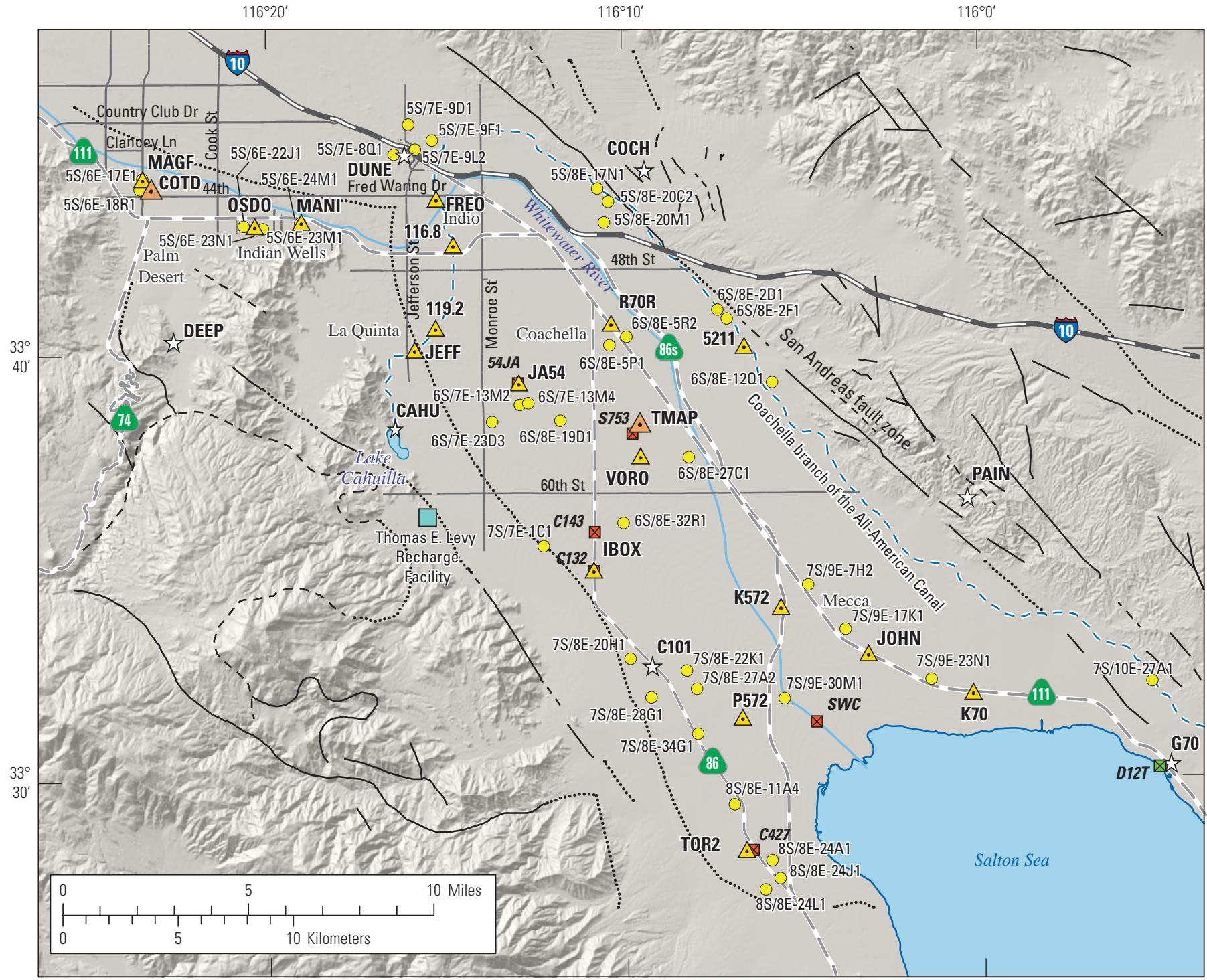

\section{EXPLANATION}

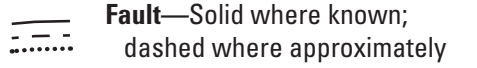

located; dotted where concealed

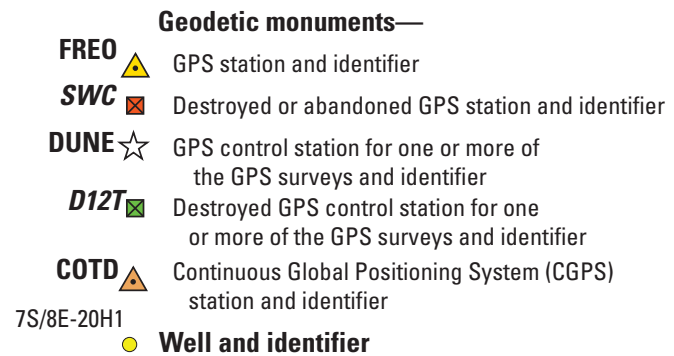

Well and identifier

Figure 3. Network of Global Positioning System (GPS) stations and wells used to monitor vertical changes in land surface and groundwater levels, respectively, in the southern Coachella Valley, California. 
The original subsidence monitoring network in the southern Coachella Valley was established in 1996 and consisted of 17 geodetic monuments. The network was modified for the 1998 GPS survey by replacing two monuments that had been destroyed (D1299 Tie, or D12T, and Caltrans 14.3 Reset 1994, or C143) with two nearby monuments ( $\mathrm{G} 701928$, or G 70, and Caltrans 13.2 1986, or C132; fig. 3). The network was again modified for the 2000 GPS survey because monument 54J A was horizontally unstable; the replacement monument (JA 54) was installed about $6 \mathrm{~m} \mathrm{(20} \mathrm{ft)} \mathrm{northwest} \mathrm{of} \mathrm{monument} \mathrm{54J} \mathrm{A} \mathrm{(fig.} \mathrm{3);} \mathrm{data}$ from both monuments were combined and are discussed together in the Global Positioning System results section. In addition, four new monuments-M A GF, M A NI, OSDO, and DEEP - were constructed and added in the Palm Desert and Indian Wells areas for the 2000 GPS survey (fig. 3) because the InSA R maps processed for 1996-2000 show ed subsidence in these areas (Sneed and others, 2001, 2002). The monument SWC had been destroyed by flooding in the Whitewater Stormwater Channel in early 2005 and, thus, could not be included in the 2005 survey (fig. 3). The network was modified and further expanded for the 2010 GPS survey. Modifications included replacing two monuments (S753 and C 132) that had been destroyed. M onument V OR O was used instead of S753, and monument IBOX was constructed near the destroyed C132 because suitable existing monuments were not available in the immediate area. M onument C 427 was replaced with nearby monument TOR 2 because a power pole next to C427 degraded the quality of GPS observations. A Iso, four monuments were added to the network (JEFF, 119.2, 116.8, and FREO) near the A II-A merican Canal to enable GPS data collection in areas where surveying by the CV WD indicated subsidence. The spacing between the monuments met the generalized netw ork design criterion established by Zilkoski and others (1997), which requires that the distance betw een local network points not exceed $10 \mathrm{~km}(6 \mathrm{mi})$.

\section{Determination of Ellipsoid Heights}

GPS measurements were taken at the geodetic monuments to determine their horizontal positions and ellipsoid heights. Ellipsoid height is the vertical distance above a geodetically defined reference ellipse; the ellipsoid that closely approximates the Earth's shape in the study area is the N orth A merican Datum of 1983 (NA D 83). Differences in ellipsoid-height between successive GPS surveys were computed and represented land-surface el evation changes at the monuments. The 1996, 1998, 2000, 2005, and 2010 GPS surveys generally followed established guidelines (Zilkoski and others, 1997), except that data from all five GPS surveys were processed with single-baseline, rather than multibaseline, software. Software used for the baseline and leastsquares adjustment computations was Trimble Geomatics Office, version 1.63 .
R eviews of processing GPS survey data with the singlebaseline compared to the multi-baseline approach are given in Han and Rizos (1995) and Øvstdal (2000). For the multibaseline approach, only independent baselines are used in the least squares adjustment; for the single-baseline approach, dependent baselines can be used in addition to the independent baselines for the least squares adjustment. Different coordinate results are likely for different selections of the independent baselines, so dependent baselines were included to approach unique network coordinate values (B eutler and others, 1987; Beck and others, 1989; Hollmann and others, 1990; Craymer and Beck, 1992; and Han and Rizos, 1995). However, the use of dependent baselines for the least squares adjustment can cause the uncertainty statistics of the adjustment to appear better than they actually are by artificially increasing the redundancy in the model (Han and Rizos, 1995; Øvstdal, 2000). To ensure that the uncertainty for the resulting netw ork coordinate values were not overstated as a result of the inclusion of dependent baselines in the least square adjustments, the ellipsoid-height uncertainty at the 95-percent confidence interval for each survey was determined from the scatter of the differential height values determined from each baseline pair prior to the least-squares adjustment. In other words, for each survey, 95 percent of heights computed from repeatedly observed baselines used in the adjustment agreed within the uncertainty stated for each of the five surveys, which ranged from \pm 20 to $\pm 50 \mathrm{~mm}( \pm 0.07$ to $\pm 0.16 \mathrm{ft})$. The maximum expected uncertainty when comparing the results from two surveys was computed by using the uncertainty for each of the two surveys and applying the root sum of squares method. Other variations to the guidelines were specific to particular surveys and are described in the following sections.

\section{Global Positioning System Survey, 1996}

GPS measurements for the 1996 survey were acquired by using 6 dual-frequency, half-wavel ength P-code GPS receivers (A shtech $L D-X I I$ and $A$ shtech $M D-X I I$ ) and chokering antennas (Dorne-M argolin) at 17 geodetic monuments betw een J une 3 and 14, 1996, to determine horizontal positions and ellipsoid heights (Ikehara and others, 1997). For this survey, the duration of the GPS data acquisition was almost three times that specified by Zilkoski and others (1997) in order to compensate for using half-wavelength GPS receivers rather than the full-wavelength GPS receivers (I kehara and others, 1997). GPS measurements were recorded at the 17 geodetic monuments on at least 2 different days during 2.5- to 3-hour observation periods (I kehara and others, 1997). "Network control stations" were designated around the perimeter of the monitoring network. Of the 17 geodetic monuments, 6 were network control stations-C101, CA HU, $\mathrm{COCH}, \mathrm{PAIN}, \mathrm{D} 12 \mathrm{~T}$, and DUNE (fig. 3); GPS measurements were recorded at these 6 stations on 3 additional days during 6 -hour observation periods. 
Determining the ellipsoid heights of the 17 geodetic monuments in the network involved 2 phases of leastsquares adjustments. During the first phase of least-squares adjustments, the horizontal coordinates and ellipsoid heights for the six Coachella Valley network control stations were determined by processing G PS measurements recorded at these stations with simultaneous measurements recorded at three Continuous G lobal Positioning System stations (D HL G, PIN 1, and CRFP) in southern California (fig. 1 ) and by using precise satellite orbital data and accurate coordinates of the CGPS stations provided by the International GPS Service (IGS) and the Scripps Orbit and Permanent A rray Center (SOPAC), respectively. The GPS observations of the CGPS stations were recorded at 30-second intervals and archived by SOPA C, a member of Southern California Integrated GPS N etwork. During the second phase of least-squares adjustments, the 6 Coachella Valley network control stations were fixed at the positions determined during the first phase, and the horizontal coordinates and ellipsoid heights of the remaining 11 monuments were calculated; the uncertainty of the ellipsoid heights was $\pm 50 \mathrm{~mm}( \pm 0.16 \mathrm{ft})$ at the 95 -percent confidence level.

\section{Global Positioning System Survey, 1998}

GPS measurements for the 1998 survey were acquired by using 5 dual-frequency, full-wavelength P-code GPS receivers (A shtech M D-X II) and choke-ring antennas (D orne-M argolin) at 17 geodetic monuments between 0 ctober 5 and 9, 1998, to determine horizontal positions and ellipsoid heights. GPS measurements were recorded at the 17 geodetic monuments on at least 2 different days during 45-minute observation periods. Of the 17 geodetic monuments, 5 were network control stations- $\mathrm{COCH}, \mathrm{CAHU}, \mathrm{PAIN}, \mathrm{C} 101$, and G 70 (fig. 3); GPS measurements were recorded at these 5 stations on 3 additional days during 4.5-hour observation periods.

Determining the ellipsoid heights of the 17 geodetic monuments in the network involved 2 phases of leastsquares adjustments. During the first phase of least-squares adjustments, horizontal coordinates and ellipsoid heights for the five Coachella Valley network control stations were determined by processing the GPS measurements recorded at these monuments with simultaneous measurements at three CGPS stations (DHLG, PIN 1, and WIDC) in southern California (fig. 1 ) and by using precise satellite orbital data and accurate coordinates of the CGPS stations provided by IGS and SOPAC, respectively. The GPS observations of the CGPS stations were recorded at 30-second intervals and archived by SOPAC. During the second phase of least-squares adjustments, the 5 Coachella Valley network control stations were fixed at the positions determined during the first phase, and the horizontal coordinates and ellipsoid heights for the other 12 monuments were calculated; the uncertainty of the ellipsoid heights was $\pm 20 \mathrm{~mm} \mathrm{(} \pm 0.07 \mathrm{ft}$ ) at the 95 -percent confidence level.

\section{Global Positioning System Survey, 2000}

GPS measurements for the 2000 survey were acquired by using 6 dual-frequency, full-wavelength, P-code GPS receivers (5 Trimble 4000SSIs and 1 Trimble 4000SSE) and compact L 1/L 2 Trimble antennas (with ground plane) at 21 geodetic monuments between A ugust 28 and September 1, 2000, to determine horizontal positions and ellipsoid heights. GPS measurements were recorded at the monuments on at least 2 different days during 35-minute observation periods. Of the 21 geodetic monuments, 6 were network control stations$\mathrm{COCH}, \mathrm{DEEP}, \mathrm{CAHU}, \mathrm{PAIN}, \mathrm{C} 101$, and G 70 (fig. 3); GPS measurements were recorded at these 6 stations on 3 additional days during 5 -hour observation periods.

Determining the ellipsoid heights of the 21 geodetic monuments in the network involved 2 phases of leastsquares adjustments. During the first phase of least-squares adjustments, horizontal coordinates and ellipsoid heights of the six Coachella Valley network control monuments were determined by processing the GPS measurements recorded at these monuments with simul taneous measurements at the same three CGPS stations (DHLG, PIN 1, and WIDC) used in processing the 1998 GPS survey data (fig. 1) and by using precise satellite orbital data and accurate coordinates of the CGPS stations provided by IGS and SOPA C, respectively. The observations at the CGPS stations were recorded at 30-second intervals and archived by SOPAC. During the second phase of least-squares adjustments, the 6 network control monuments were fixed at the positions determined during the first phase, and the horizontal coordinates and ellipsoid heights for the other 15 monuments were calculated; the uncertainty of the ellipsoid heights was $\pm 30 \mathrm{~mm}( \pm 0.10 \mathrm{ft})$ at the 95 -percent confidence level.

\section{Global Positioning System Survey, 2005}

GPS measurements for the 2005 survey were acquired using 6 dual-frequency, full-wavelength, P-code GPS receivers (Topcon GB 1000) and compact antennas with ground plane (Topcon PG-A 1 Geodetic) at 20 geodetic monuments between A ugust 15 and 19,2005, to determine horizontal positions and ellipsoid heights. GPS measurements were recorded at the monuments on at least 2 different days during 1-hour observation periods. Of the 20 geodetic monuments, 6 were network control stations- $\mathrm{COCH}, \mathrm{DEEP}, \mathrm{CAHU}, \mathrm{PA}$ IN, C 101, and G70 (fig. 3); GPS measurements were recorded at these six stations on 3 additional days during 6.5-hour observation periods.

Determining the ellipsoid heights of the 20 geodetic monuments in the network involved 2 phases of leastsquares adjustments. During the first phase of least-squares adjustments, horizontal coordinates and ellipsoid heights of the six Coachella Valley network control monuments were determined by processing the GPS measurements recorded at these monuments with simultaneous measurements at the same three CGPS stations (DHLG, PIN 1, and WIDC) used in 
the 1998 and 2000 GPS surveys and by using precise satellite orbital data and accurate coordinates of the CGPS stations provided by IGS and SOPAC, respectively. The measurements at the CGPS stations were recorded at 30 second intervals and archived by SOPA C. During the second phase of least-squares adjustments, the 6 network control stations were fixed at the positions determined during the first phase, and the horizontal coordinates and ellipsoid heights for the other 14 monuments were cal culated; the uncertainty of the ellipsoid heights was $\pm 20 \mathrm{~mm}( \pm 0.07 \mathrm{ft})$ at the 95 -percent confidence level.

\section{Global Positioning System Survey, 2010}

GPS measurements for the 2010 survey were acquired using 7 dual-frequency, full-wavelength, P-code GPS receivers (Topcon GB 1000) and compact antennas with ground plane (Topcon PG-A 1 G eodetic) at 24 geodetic monuments betw een A ugust 23 and 27, 2010, to determine horizontal positions and ellipsoid heights. GPS measurements were recorded at the monuments on at least 2 different days during 1-hour observation periods. Of the 24 geodetic monuments, 7 were network control stations-DUNE, COCH, DEEP, CAHU, PA IN , C 101, and G70 (fig. 3); GPS measurements were recorded at these seven stations on 3 additional days during 6.5-hour observation periods.

Determining the ellipsoid heights of the 24 geodetic monuments in the network involved 2 phases of leastsquares adjustments. During the first phase of least-squares adjustments, horizontal coordinates and ellipsoid heights of the seven Coachella Valley netw ork control monuments were determined by processing the GPS measurements taken at these monuments with simultaneous measurements at the same three CGPS stations (D HLG, PIN 1, and WIDC) used in the 1998, 2000, and 2005 GPS surveys and by using precise satellite orbital data and accurate coordinates of the CGPS stations provided by IGS and SOPAC, respectively. The measurements at the CGPS stations were recorded at 30 second intervals and archived by SOPAC. During the second phase of least-squares adjustments, the 7 network control monuments were fixed at the positions determined during the first phase, and the horizontal coordinates and ellipsoid heights for the other 17 monuments were calculated; the uncertainty of the ellipsoid heights was $\pm 20 \mathrm{~mm}( \pm 0.07 \mathrm{ft}$ ) at the 95-percent confidence level.

\section{Global Positioning System Results}

For each of the five GPS surveys, the horizontal coordinates and the ellipsoid heights of the monuments were compared to determine the magnitude of horizontal and vertical land-surface changes, respectively. The horizontal changes at the monuments were consistent with the northwest movement of the Pacific Plate with respect to the North A merican plate (Shen and others, 2003). The monument ellipsoid heights and their changes with respect to the first GPS measurement at each monument are tabulated in table 1 and graphed as a function of time in figure 4; additionally, the monument ellipsoid-height changes for 1996-2010 and 2005-10 are tabulated in table 1 .

Differences in calculated ellipsoid heights at the 11 geodetic monuments surveyed in 1996 and 2010 in the southern Coachella Valley indicated that the calculated ellipsoid heights at these monuments decreased 23-136 mm (0.08-0.45 ft; table 1; fig. 4). The maximum uncertainty expected for these calculated changes in ellipsoid heights was $\pm 54 \mathrm{~mm}( \pm 0.18 \mathrm{ft})$ at the 95 -percent confidence level. B ecause changes at 6 of the 11 monuments (DUNE, R 70R, CA HU, K 572, C101, and P572) exceeded this, the land surface probably subsided at these monuments between J une 1996 and A ugust 2010 (figs. 4A, 4F, 4J, 4N, 4P, 4R). Ellipsoidheight changes at 5 of the 11 monuments $(\mathrm{COCH}, 5211$, PAIN, $\mathrm{JOHN}$, and $\mathrm{K} 70$ ) did not exceed the maximum expected uncertainty, which indicates that the vertical positions of these monuments were similar in June 1996 and in A ugust 2010 (figs. $4 B, 4 H, 4 L, 4 O, 4 Q$ ).

Differences in calculated ellipsoid heights at 17 monuments surveyed in 2005 and 2010 indicated changes from -256 to $+16 \mathrm{~mm}(-0.84$ to $+0.05 \mathrm{ft})$ during this 5 -year period (table 1; fig. 4). The maximum uncertainty expected for these calculated changes in ellipsoid heights was $\pm 28 \mathrm{~mm}$ $( \pm 0.09 \mathrm{ft})$ at the 95 -percent confidence level. Changes at 5 of the 17 monuments (M A GF, M A NI, OSD O, R 70R, and JA 54) exceeded the maximum expected uncertainty, indicating that land surfaces at these 5 monuments subsided between A ugust 2005 and A ugust 2010 (figs. 4C, 4D, 4E, 4F, 4I). These monuments also significantly subsided between 2000 and 2005 (Sneed and B randt, 2007). For 2005-10, OSD 0 subsided at the fastest rate- 51 millimeters per year $(\mathrm{mm} / \mathrm{yr})$, or 0.17 foot per year (ft/yr), followed by M A GF $(31 \mathrm{~mm} / \mathrm{yr}$, or $0.10 \mathrm{ft} / \mathrm{yr})$, JA 54 ( $15 \mathrm{~mm} / \mathrm{yr}$, or $0.05 \mathrm{ft} / \mathrm{yr})$, M ANI $(9 \mathrm{~mm} / \mathrm{yr}$, or $0.03 \mathrm{ft} / \mathrm{yr})$, and $R 70 R(6 \mathrm{~mm} / \mathrm{yr}$, or $0.02 \mathrm{ft} / \mathrm{yr})$. These rates were similar to those calculated for the same monuments for 2000- 05 (Sneed and B randt, 2007). Ellipsoid-height changes at 12 of the 17 monuments (DUNE, COCH, DEEP, 5211, CAHU, PAIN , K 572, JOHN , C101, K 70, P572, and G 70) did not exceed the maximum expected uncertainty, indicating land-surface elevations at these monuments were similar in A ugust 2005 and A ugust 2010 (figs. 4A, 4B, 4G, 4H, 4J, 4L, $4 N, 4 O, 4 P, 4 Q, 4 R, 4 T)$. 


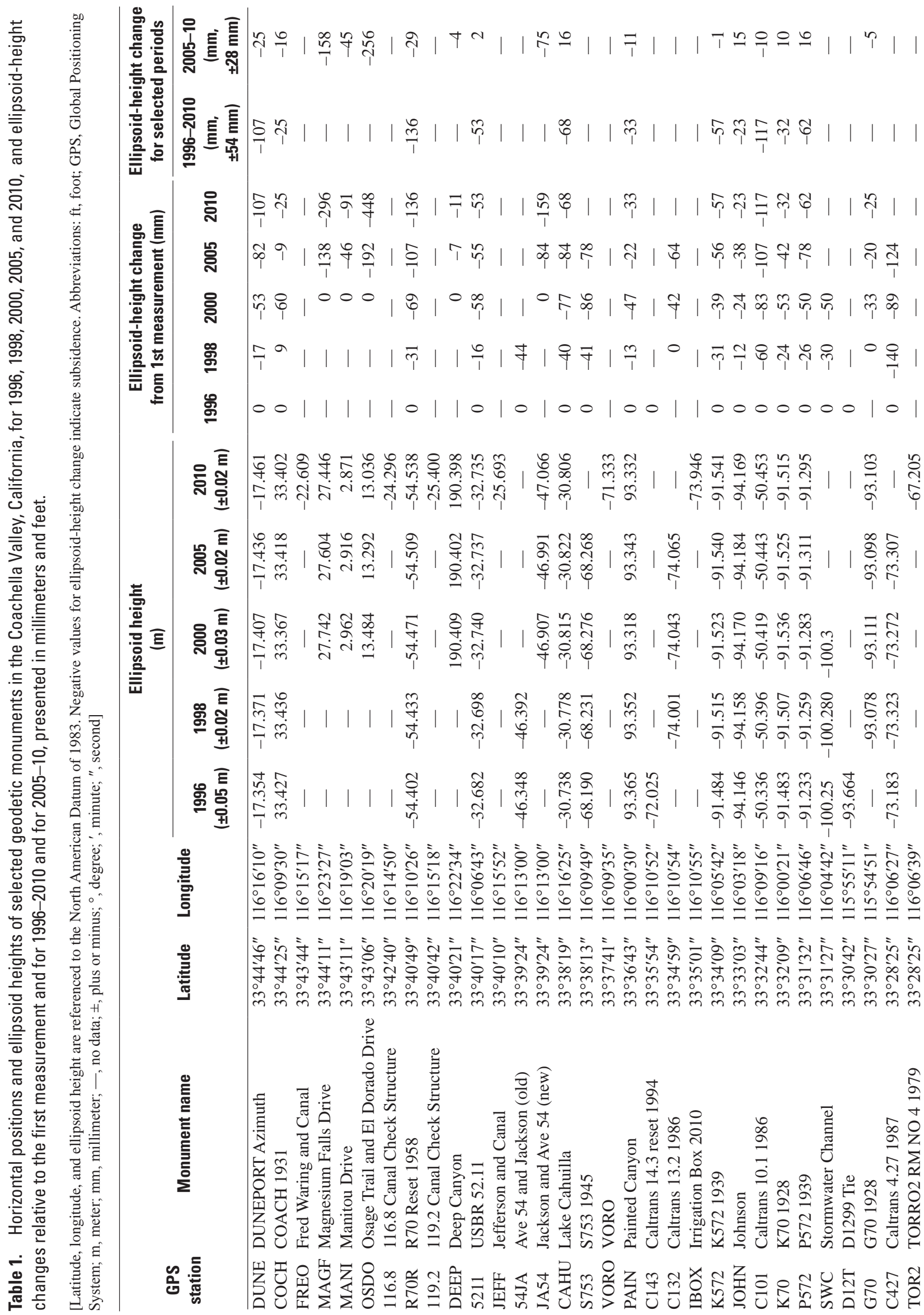




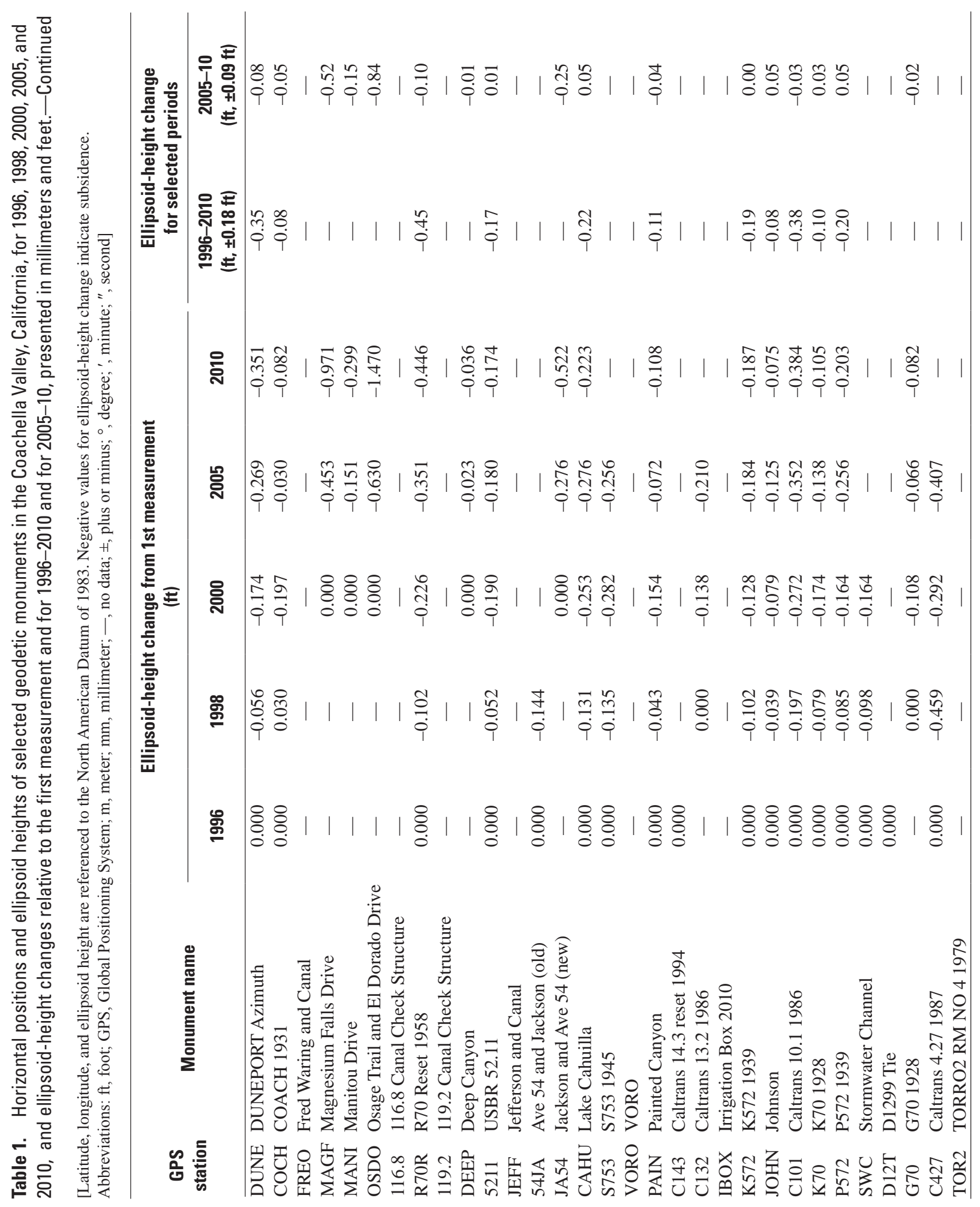




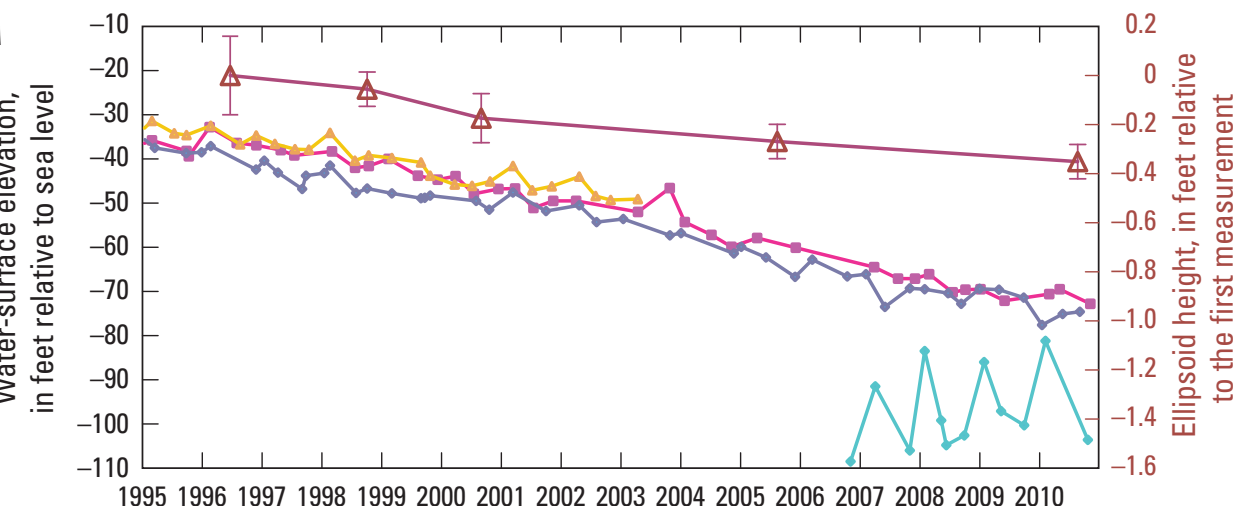

EXPLANATION

$\longrightarrow$ - 5S/7E-801

(screened in the upper aquifer) 5S/7E-9F1

(screened in the perched and upper aquifers)

$\longrightarrow$ 5S/7E-9L2

(screened in the upper aquifer) 5S/7E-9D1

$\triangle$ DUNE

1995199619971998199920002001200220032004200520062007200820092010

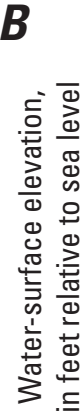

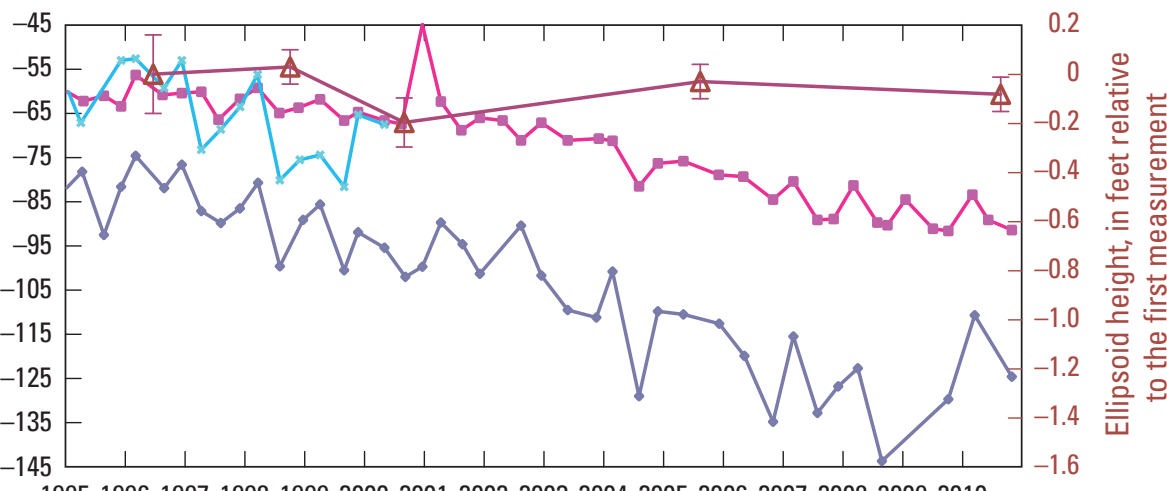

$$
\begin{aligned}
& \longrightarrow \text { 5S/8E-17N1 } \\
& \text { (screened in the upper aquifer) } \\
& -5 \mathrm{~S} / 8 \mathrm{E}-20 \mathrm{M} 1 \\
& \text { (screened in the lower aquifer) } \\
& -5 \mathrm{~S} / 8 \mathrm{E}-20 \mathrm{C} 2 \\
& \text { (screened in the upper aquifer) } \\
& \triangle \quad \text { COCH }
\end{aligned}
$$

1995199619971998199920002001200220032004200520062007200820092010

C

.

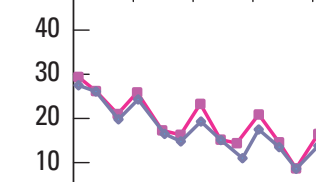

$0-$

$-10-$

$-20-$

$-30-$

$-40-$

\section{D}

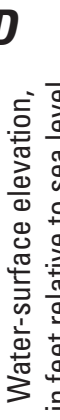

50

1995199619971998199920002001200220032004200520062007200820092010

40
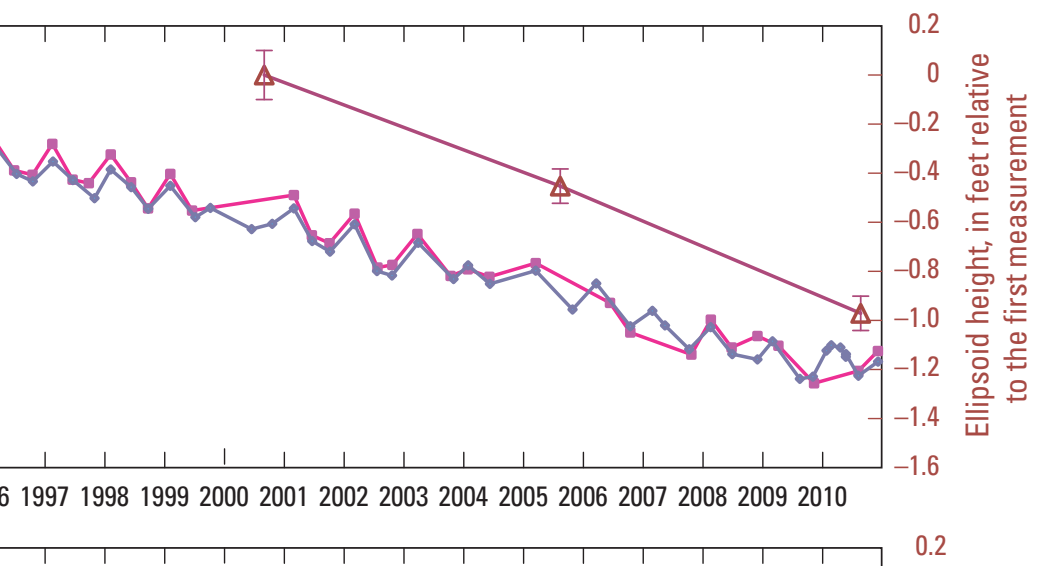
$\longrightarrow$ 5S/6E-17E1
(screened in the lower aquifer) $\longrightarrow$ 5S/6E-18R1 (screened in the lower aquifer) $\triangle$ MAGF

$-5 \mathrm{~S} / 6 \mathrm{E}-24 \mathrm{M} 1$ (screened in the upper and lower aquifers)

$\triangle$ MANI

Figure 4. Water-surface elevations for selected wells between 1995 and 2010, and ellipsoid-height changes relative to the first measurement for the following geodetic monuments: $A$, DUNE; $B$, COCH; C, MAGF; D, MANI; E, OSDO; F, R70R; G, DEEP; H, 5211; I, 54JA/ JA54; J, CAHU; K, S753; L, PAIN; $M$, C132; N, K572; O, JOHN; P, C101; Q, K70; R, P572; S, SWC; T, G70; and, U, C427. See figure 3 for the locations of wells and geodetic monuments. 


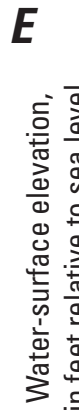
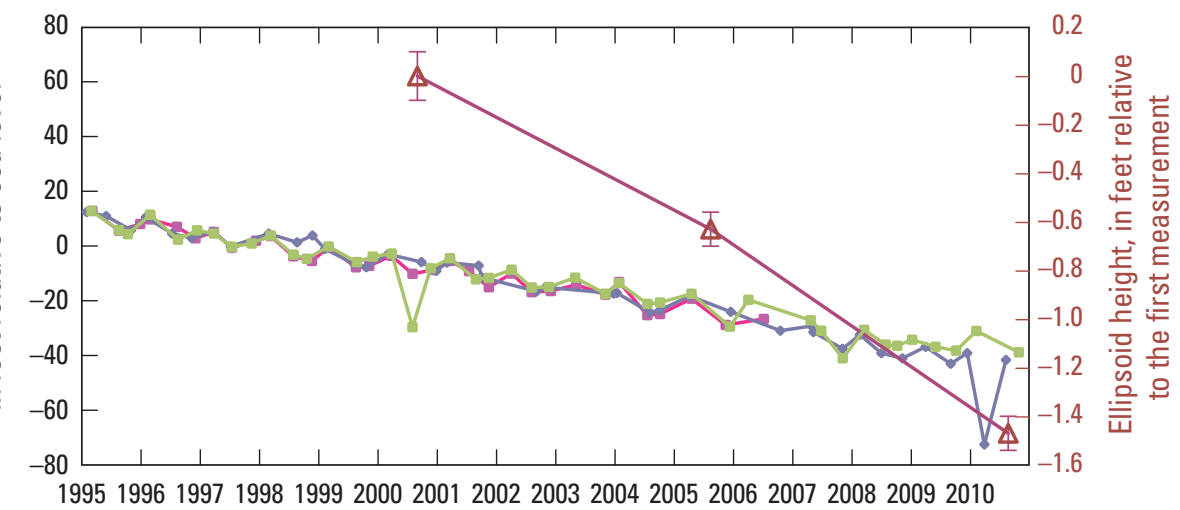

$\boldsymbol{F}$
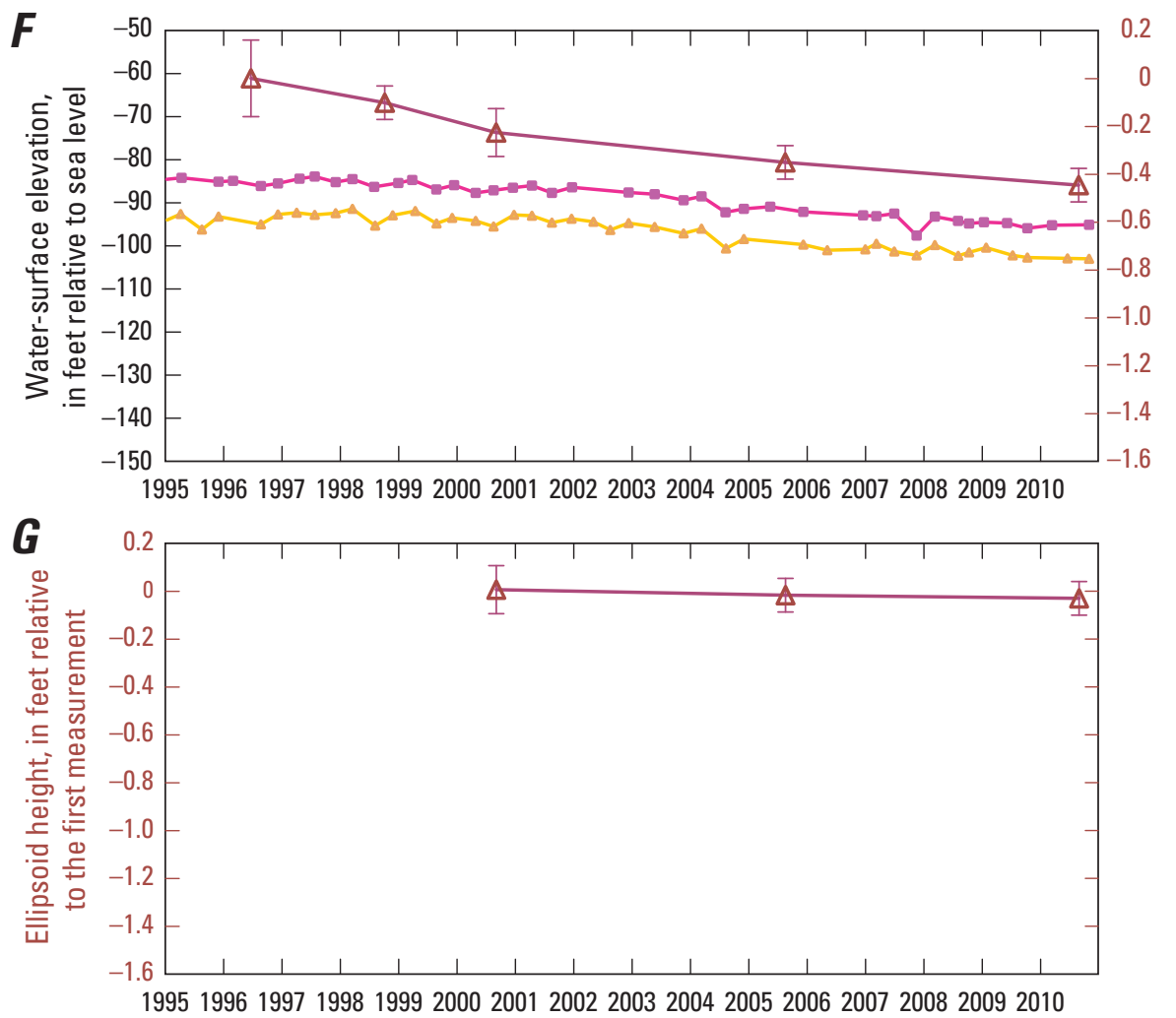

$H$

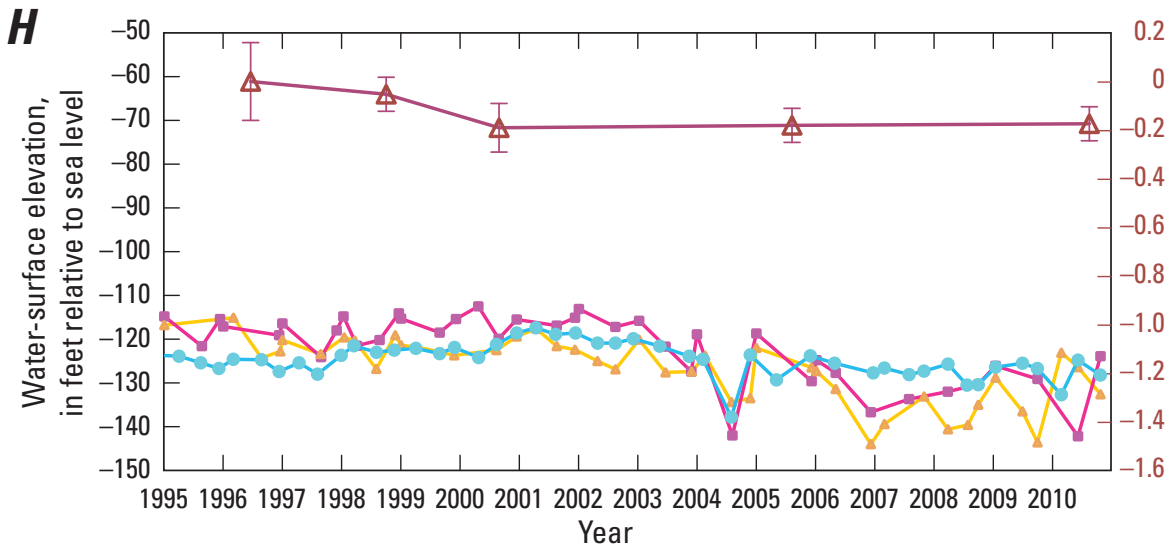

\section{EXPLANATION}

$\longrightarrow$ - $5 \mathrm{~S} / 6 \mathrm{E}-23 \mathrm{M} 1$

(screened in the upper and lower aquifers)

$\longrightarrow$ 5S/6E-22J1

(screened in the lower aquifer)

$\longrightarrow$ 5S/6E-23N1

(screened in the upper aquifer)

$\triangle$ OSDO
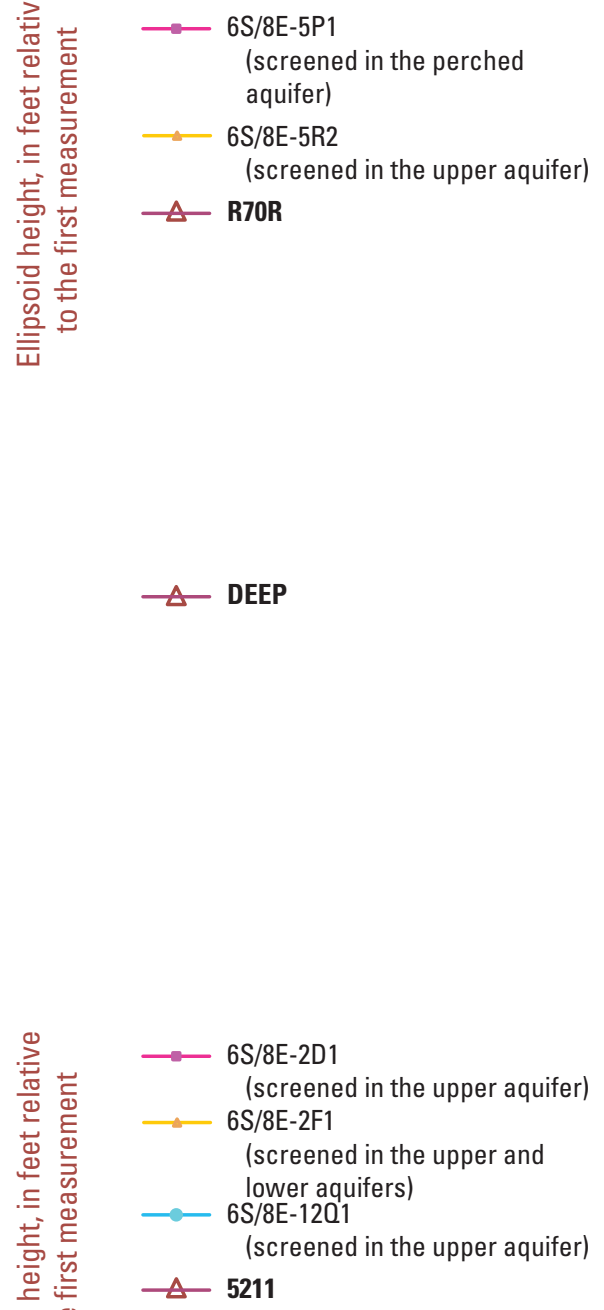

Figure 4. - Continued 
I

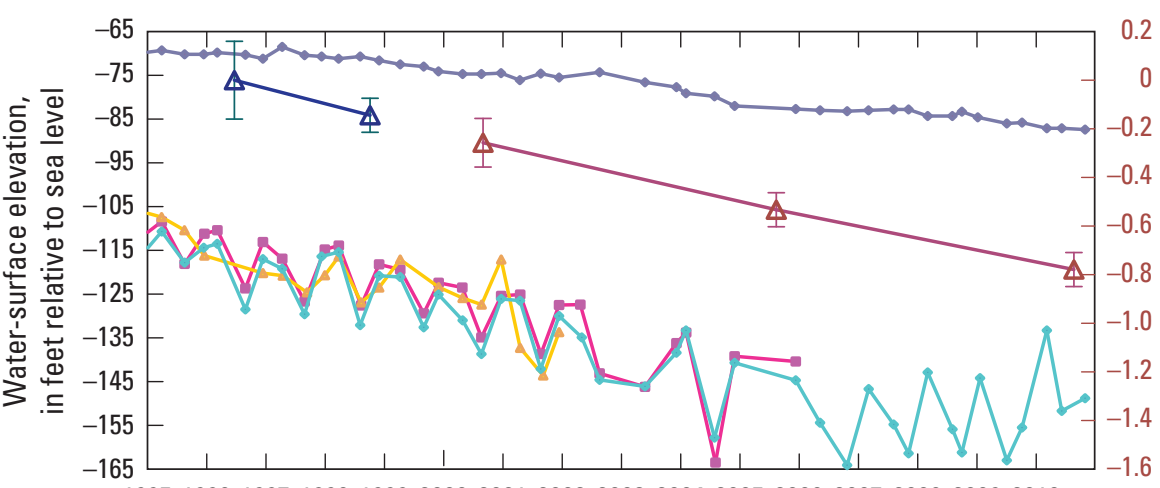

1995199619971998199920002001200220032004200520062007200820092010
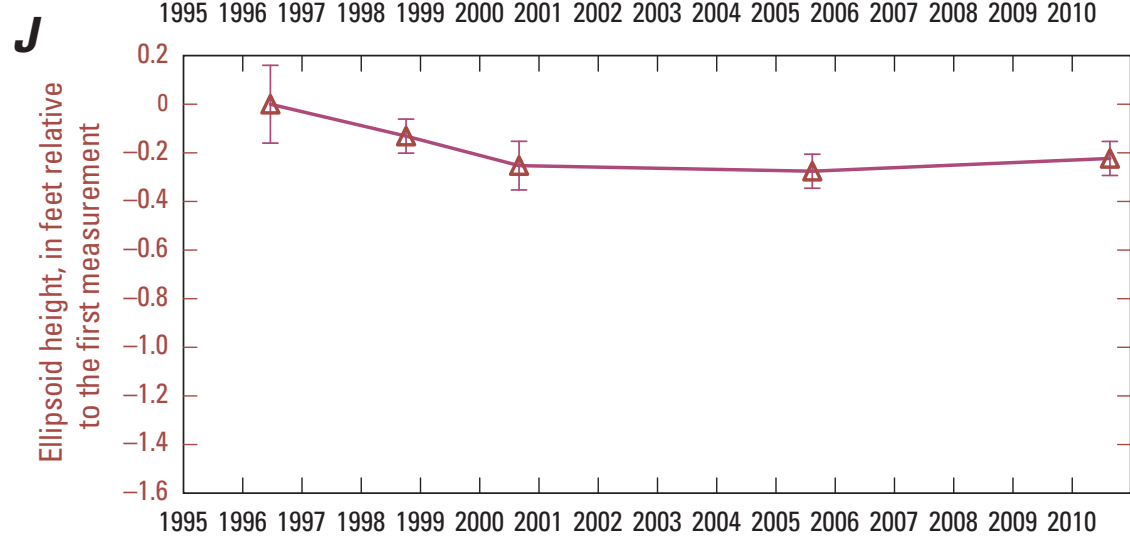

$\boldsymbol{K}$

.

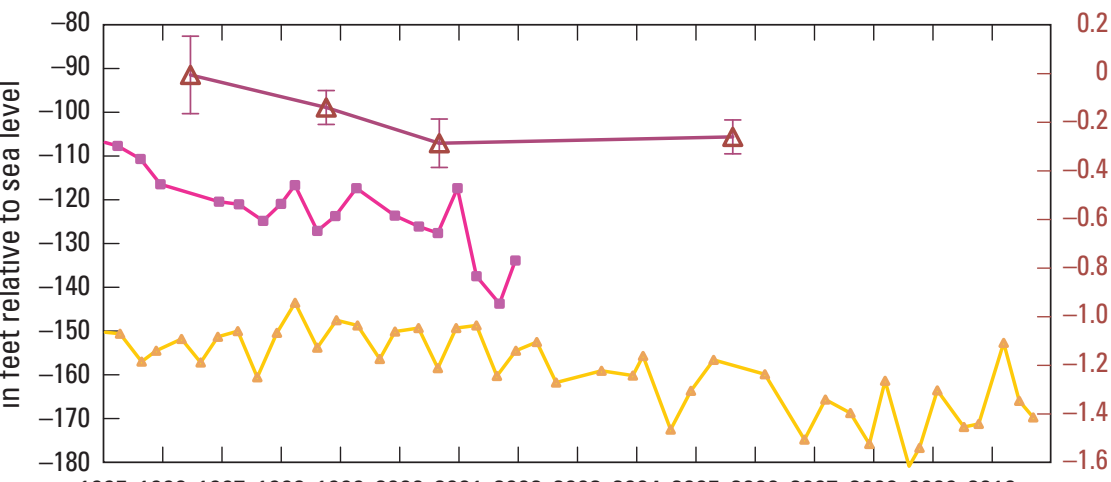

1995199619971998199920002001200220032004200520062007200820092010

$L$

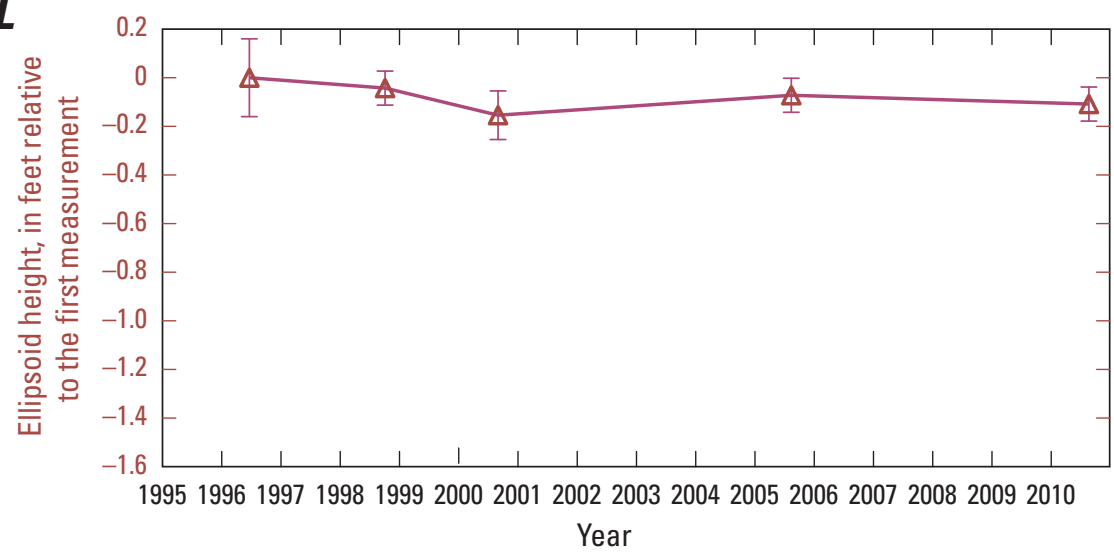

EXPLANATION

$\longrightarrow 6 \mathrm{~S} / 7 \mathrm{E}-23 \mathrm{D} 3$

(screened in the upper aquifer) 6S/8E-19D1

(screened in the lower aquifer) 6S/7E-13M2

(screened in the upper aquifer) 6S/7E-13M4

(screened in the lower aquifer)

A 54JA (old mark)

$\triangle \triangle$ JA54 (new mark)

$\triangle$ CAHU $\longrightarrow 6 \mathrm{~S} / 8 \mathrm{E}-19 \mathrm{D} 1$

(screened in the lower aquifer) $6 \mathrm{~S} / 8 \mathrm{E}-27 \mathrm{C} 1$

(screened in the upper and lower aquifers

Figure 4. - Continued 
M

$M$

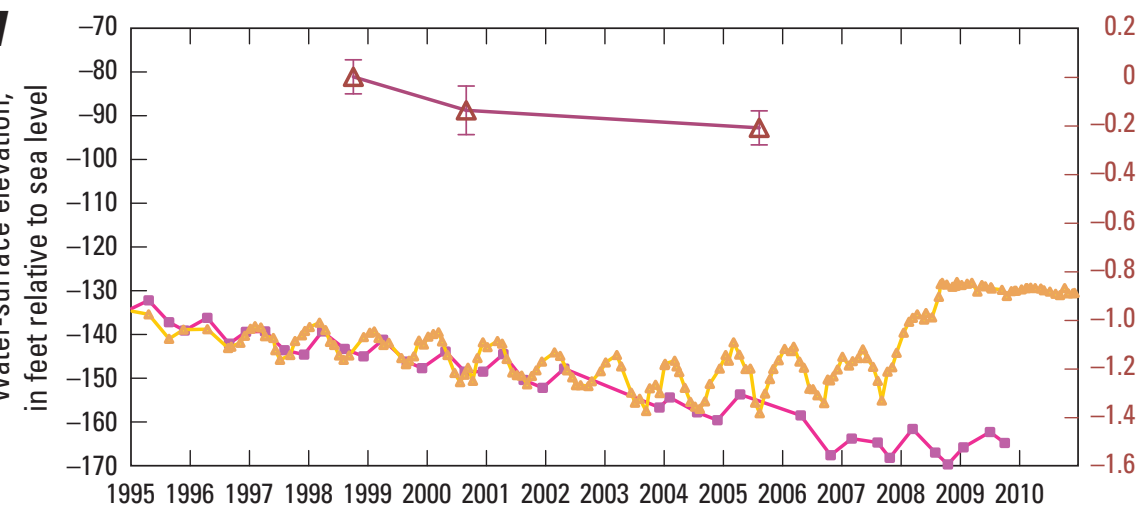

N

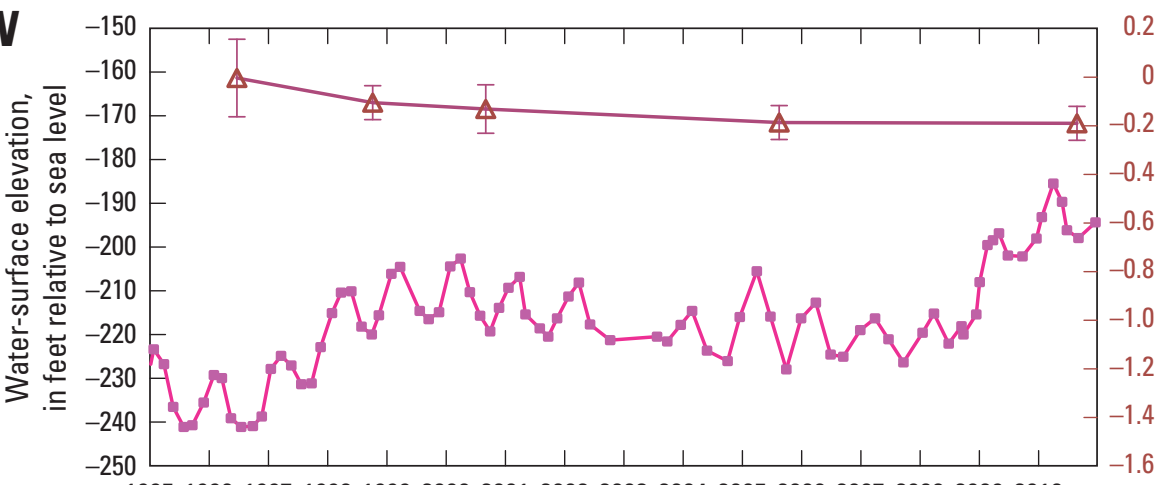

1995199619971998199920002001200220032004200520062007200820092010

0

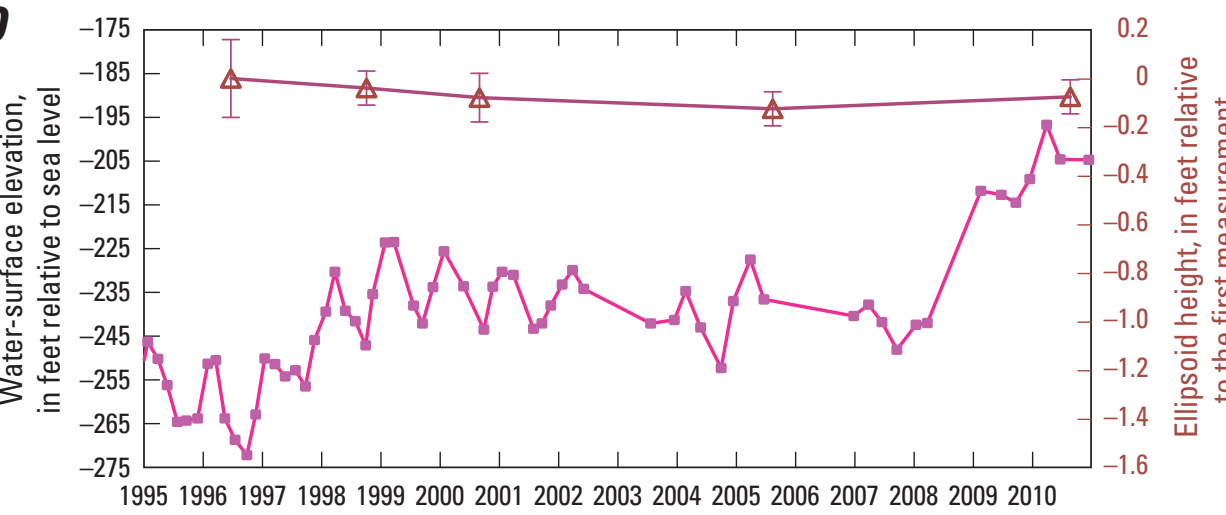

$P$

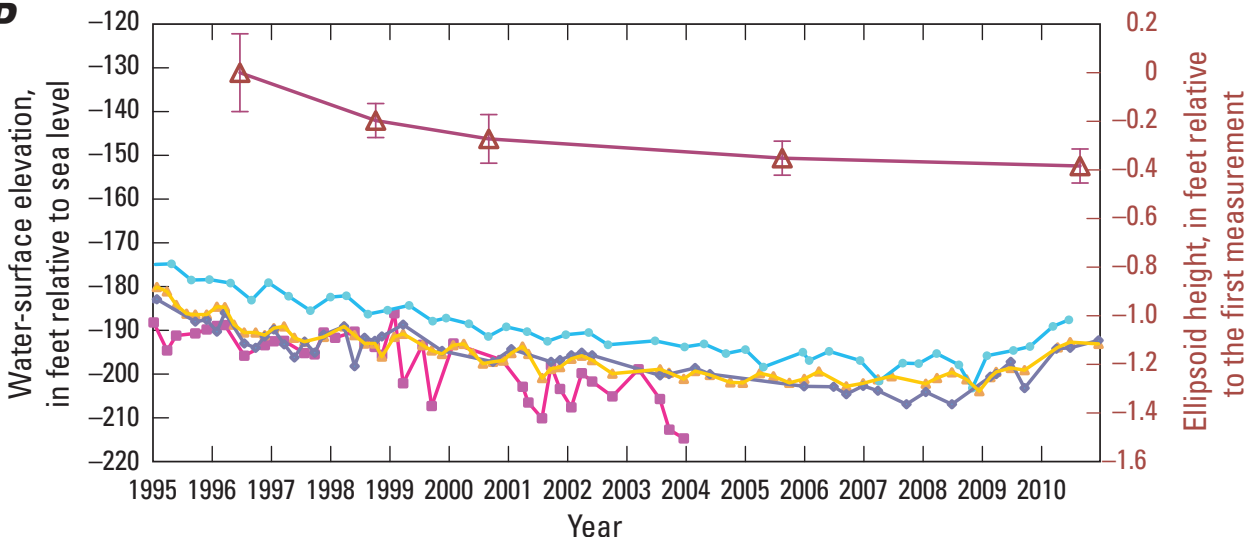

EXPLANATION

$\longrightarrow-6 \mathrm{~S} / 8 \mathrm{E}-32 \mathrm{R} 1$

(screened in the perched, upper and lower aquifers)

7S/7E-1C1

(screened in the upper aquifer)

$\Delta-C 132$

$\longrightarrow$ 7S/9E-7H2

(screened in the upper aquifer)

$\triangle \mathrm{K} 572$

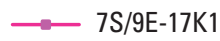

(screened in the upper and lower aquifers)

$\triangle$ JOHN

$\longrightarrow$ 7S/8E-22K1

(screened in the upper and lower aquifers)

7S/8E-28G

(screened in the upper aquifer) 7S/8E-20H1

(screened in the upper aquifer) 7S/8E-27A2

(screened in the lower aquifer)

Figure 4. - Continued 
0

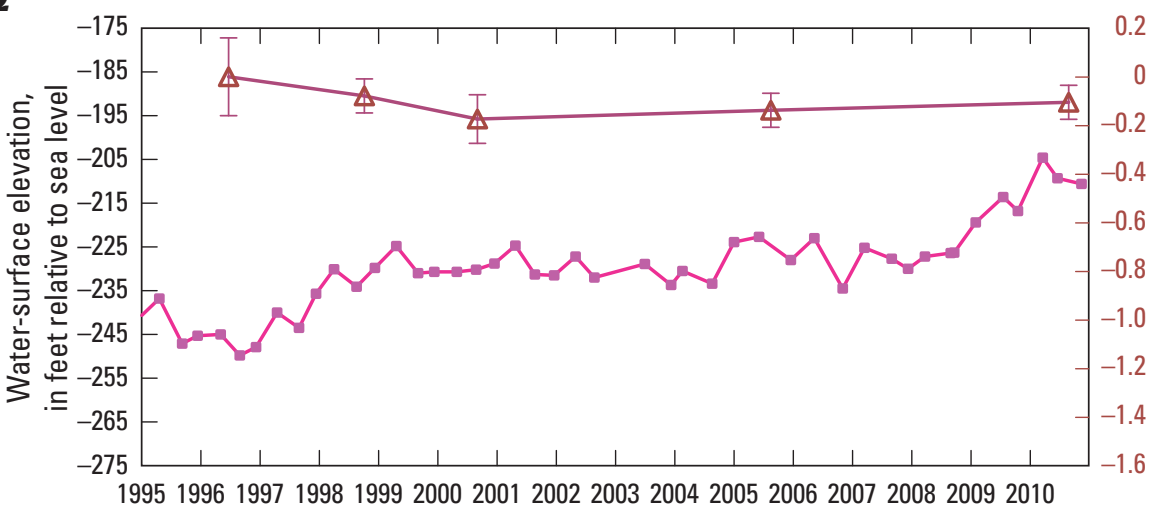

R

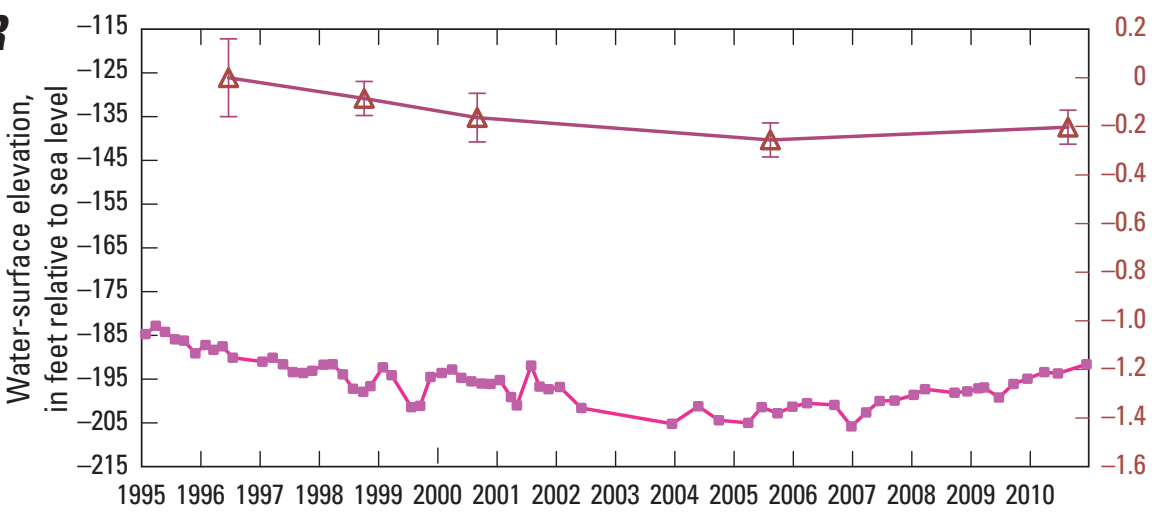

$\boldsymbol{S}$

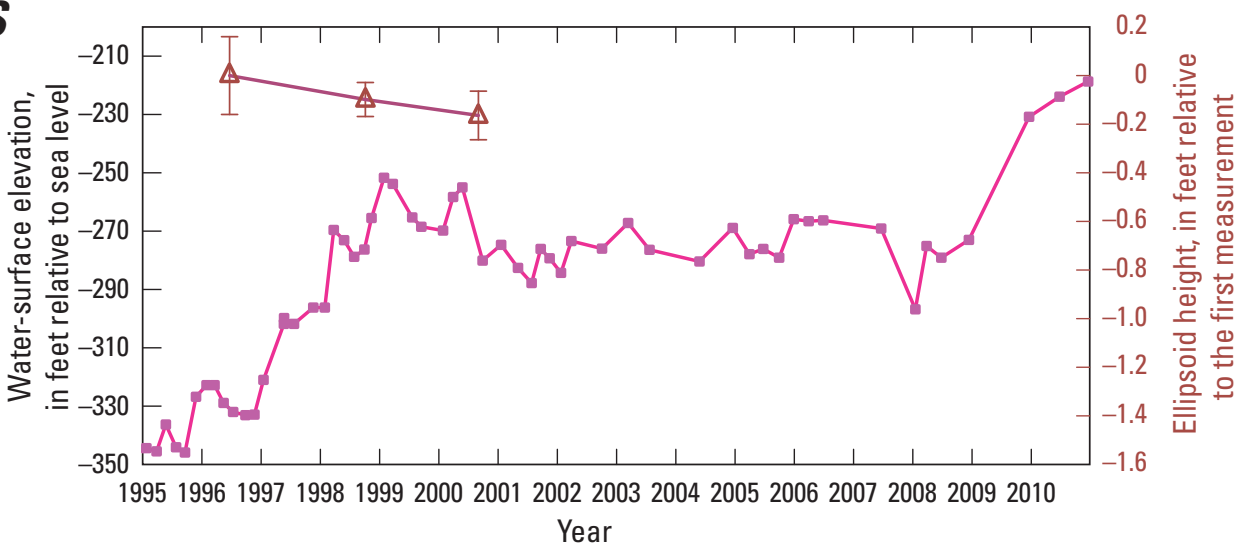

EXPLANATION

7S/9E-23N1

(screened in the upper aquifer)

$\triangle \mathrm{K} 70$ $\longrightarrow 7 \mathrm{~S} / 8 \mathrm{E}-34 \mathrm{G} 1$

(screened in the perched aquifer)

$\triangle$ P572
7S/9E-30M1

(screened in the perched and upper aquifers)

$\triangle$ SWC

Figure 4. - Continued 
$T$

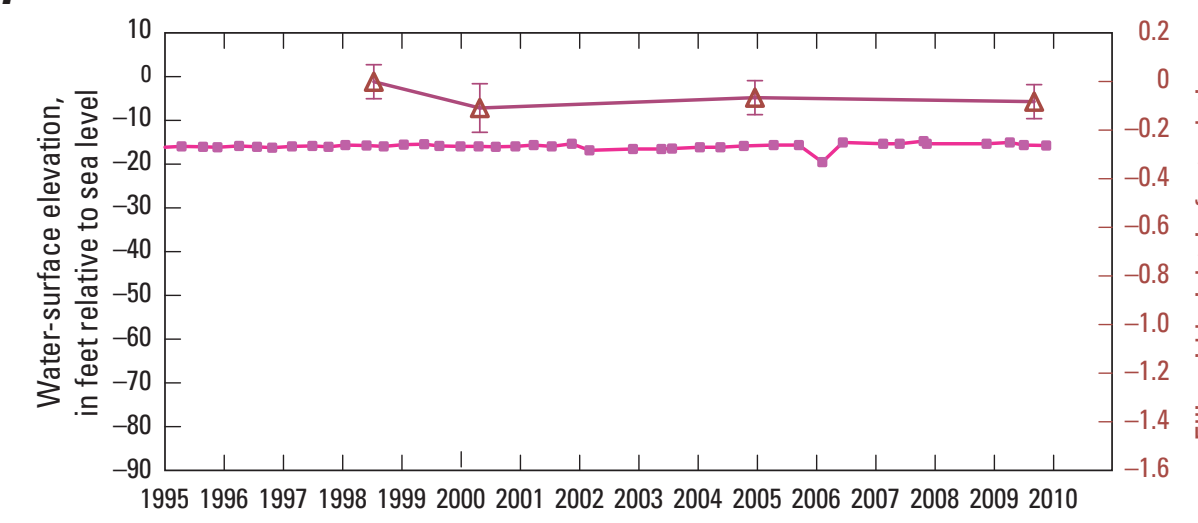

$\boldsymbol{U}$

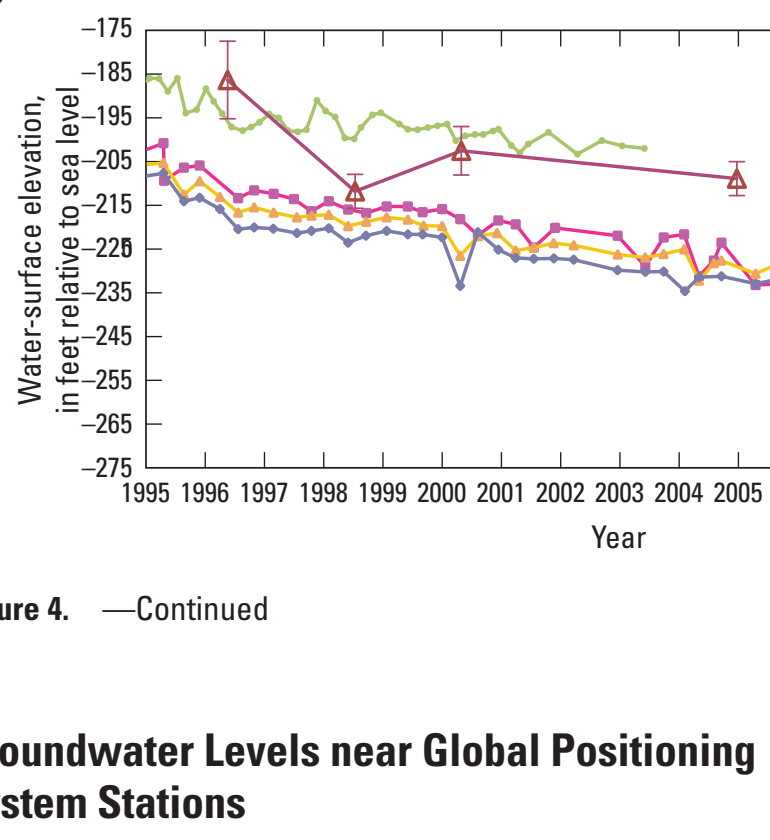

In the northern and central parts of the geodetic network (near DUNE, MAGF, MANI, OSDO, R 70R, and JA 54/54JA), where significant subsidence was measured by 2010 , water levels generally showed seasonal fluctuations superimposed on longer-term water-level declines during 1995-2010 (figs. 4A, 4C, 4D, 4E, 4F, 4I) and earlier (fig. 5A). In the northeastern part of the geodetic network near $\mathrm{COCH}$ and 5211, where land-surface el evations were fairly stable, water levels generally showed seasonal fluctuations superimposed on longer-term water-level declines during 1995-2010 (figs. $4 B, 4 H$ ); the longer-term declines were larger near $\mathrm{COCH}$. The stable land-surface elevations at $\mathrm{COCH}$ in the presence of declining water levels could be due to the following: (1) $\mathrm{COCH}$ is located on a hill composed of the partly consolidated sediments of the Indio Hills rather than unconsolidated sediments of the valley floor, and (2) the wells near $\mathrm{COCH}$ (shown with $\mathrm{COCH}$ on $4 B$ ) do not adequately represent water levels at $\mathrm{COCH}$ because they are on the west side of the San A ndreas Fault, whereas $\mathrm{COCH}$ is on the east side of the fault (fig. 3).
In the southwestern part of the geodetic network (near C 101 and P572), where subsidence was measured by 2005 (Sneed and B randt, 2007), subsidence rates slowed at C101 and the calculated ellipsoid height increased at P572 during 2005- 10 (figs. 4P, 4R). Water-level records from nearby wells 7S/8E-28G 1, -20H 1, -27A 2, and -34G 1 generally showed seasonal fluctuations superimposed on water-level declines between 1995 (or earlier) and 2007 or 2008, followed by water-level recovery (figs. $4 P, 4 R, 5 B$ ). This recovery coincided with increased Colorado River water deliveries to the Thomas E. L evy Recharge Facility (figs. 3, 6). In the southcentral and southeastern parts of the geodetic network (near K 572, JOH N, K 70, and G 70), where land-surface el evations have been fairly stable and water levels have been stable or recovering since 1995 after decades of decline, a substantial recovery event was indicated in some wells beginning in 2008-again coinciding with increased deliveries to the Thomas E. Levy Recharge Facility (figs. 3, $4 \mathrm{~N}, 4 \mathrm{O}$, $4 Q, 5 B, 6)$. The coincident timing of increased deliveries to the recharge ponds and substantial water-level recoveries indicated that the water applied to the recharge ponds was effectively increasing the head in the aquifer system. Decreased pumping or recharge from another source, however, al so could cause water levels to stabilize or recover. 
A

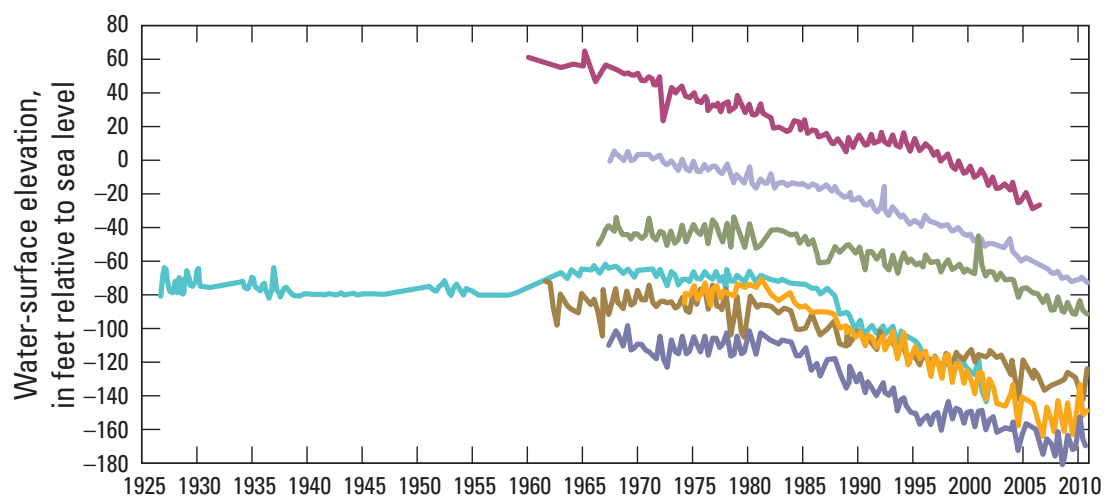

EXPLANATION

5S/7E-801 (screened in the upper aquifer) $5 \mathrm{~S} / 8 \mathrm{E}-17 \mathrm{~N} 1$ (screened in the upper aquifer) $5 \mathrm{~S} / 6 \mathrm{E}-23 \mathrm{M} 1$ (screened in the upper and lower aquifers)

$6 \mathrm{~S} / 8 \mathrm{E}-19 \mathrm{D} 1$ (screened in the lower aquifer) $6 \mathrm{~S} / 8 \mathrm{E}-2 \mathrm{D} 1$ (screened in the upper aquifer) $6 S / 7 E-13 M 4$ (screened in the lower aquifer) $6 \mathrm{~S} / 8 \mathrm{E}-27 \mathrm{C} 1$ (screened in the upper and lower aquifers)
B

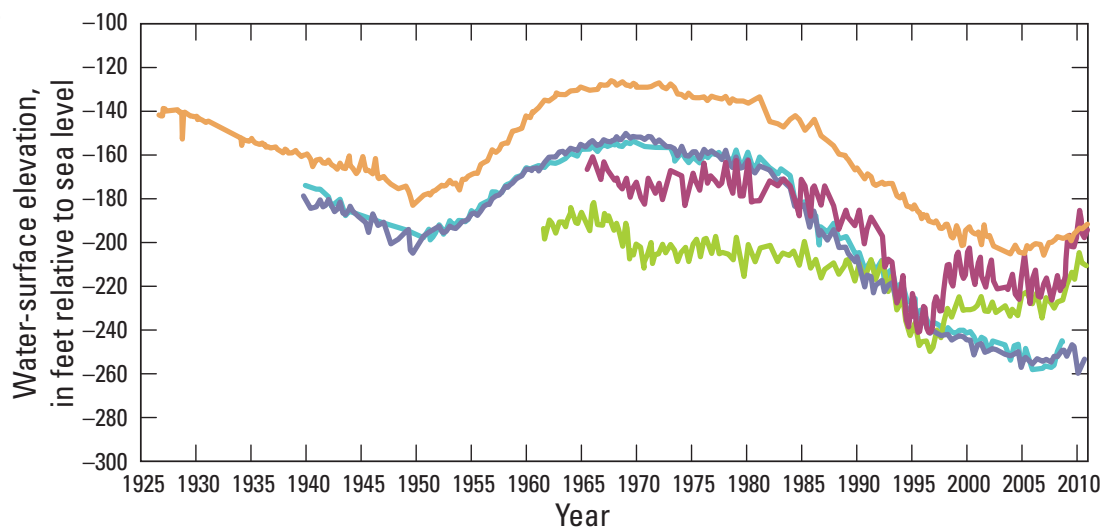

- 8S/8E-24A1 (screened in the lower aquifer) 7S/9E-23N1 (screened in the upper aquifer) 8S/8E-24L1 (screened in the upper aquifer) $7 \mathrm{~S} / 9 \mathrm{E}-7 \mathrm{H} 2$ (screened in the upper aquifer) $7 \mathrm{~S} / 8 \mathrm{E}-34 \mathrm{G} 1$ (screened in the perched aquifer)

Figure 5. Water-surface elevations, 1925-2010, for wells in $A$, the northern and central parts of the subsidence monitoring network; and $B$, the southern part of the subsidence monitoring network. See figure 3 for the locations of wells.

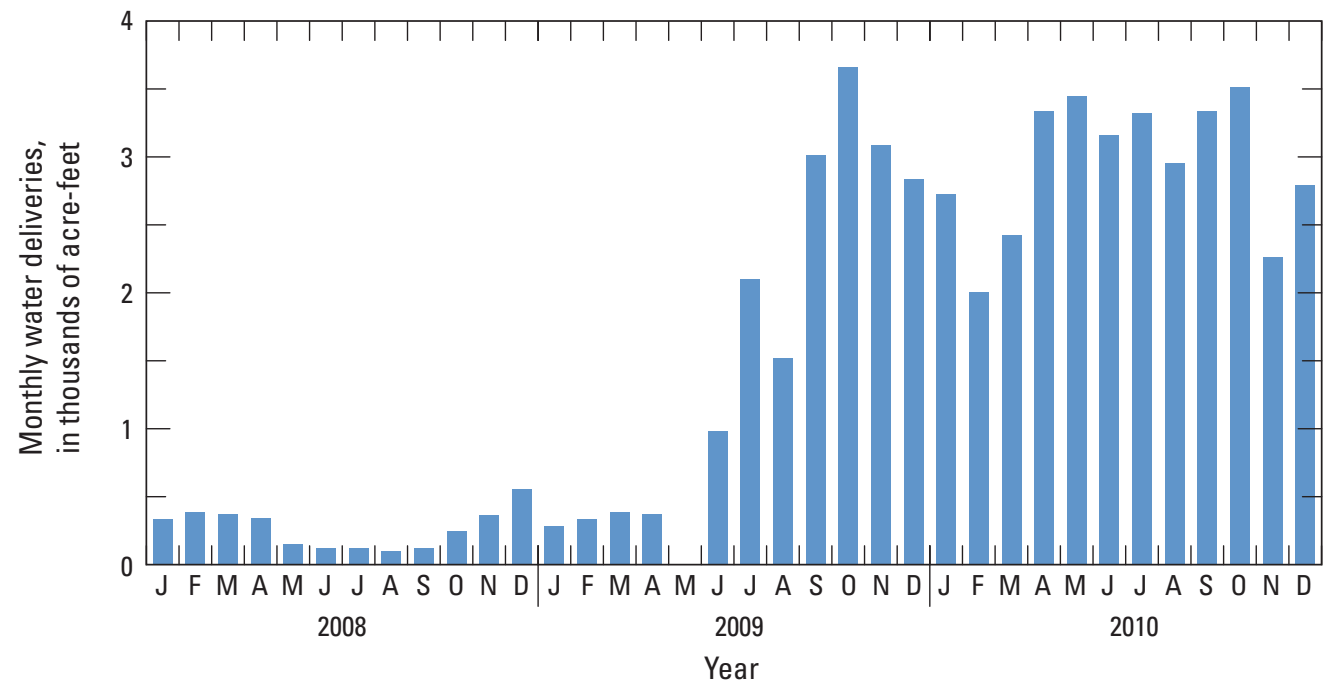

EXPLANATION

Monthly water deliveries to Thomas E. Levy Recharge Facility

Figure 6. Water deliveries to the Thomas E. Levy Recharge Facility for 2008-10. See figure 3 for the location of the Thomas E. Levy Recharge Facility.

A lthough groundwater-level changes are the likely cause of the observed land-surface el evation changes, tectonicallyinduced crustal movements in the area could have a vertical component. However, because the CGPS stations on the margins of the valley that were used for the GPS network adjustments were fairly stable between 1996 and 2010, vertical crustal motion probably did not contribute much to the el evation changes measured at other geodetic monuments in the network. 


\section{Interferometric Synthetic Aperture Radar Methodology}

InSA R is a satellite-based remote sensing technique that can detect centimeter-level ground-surface deformation over hundreds of square kilometers at a spatial resolution (pixel size) of $90 \mathrm{~m}$ (295 ft) or better (B awden and others, 2003). Synthetic A perture Radar (SAR) imagery is produced by reflecting radar signals off a target area and measuring the two-way travel time back to the satellite. InSA R uses two SAR scenes of the same area taken at different times and "interferes" (differences) them, resulting in maps called interferograms that show relative ground-el evation change (range change) between the two times. SA R imagery has two components: amplitude and phase. The amplitude is the radar signal intensity returned to the satellite and depends upon the varying reflective properties that delineate features of the landscape, such as roads, mountains, structures, and other features (fig. 7). The phase component is proportional to the line-of-sight distance from the ground to the satellite (range) and is used to measure land-surface displacement (subsidence or uplift). If the ground has moved away from the satellite (subsidence), a more distal phase portion of the waveform is reflected back to the satellite. Conversely, if the ground has moved closer to the satellite (uplift), a more proximal phase portion of the waveform is reflected back to the satellite (Sneed and B randt, 2007). The phase difference, or shift, betw een the two SAR images is then calculated for each pixel relative to a selected reference pixel within the image extent. The map of phase shifts, or interferogram, can be depicted with a color scale that shows relative range change between the first and the second acquisitions. The indicated range change is about 90 to 95 percent of true vertical ground motion, depending on the satellite look angle and the location of the target area.

InSAR signal quality depends partly on satellite position, atmospheric conditions, ground cover, land-use practices, and timespan of the interferogram. Strict orbital control is required to precisely control the look angle and position of the satellite. Successful application of the InSA R technique is contingent on looking at the same point on the ground from nearly the same position in space so that the horizontal distance between each satellite pass, or perpendicular baseline, is minimized. Perpendicular baselines greater than about $200 \mathrm{~m}(656 \mathrm{ft})$ can produce excessive topographic effects (parallax) that can mask range changes. The relatively flat topography of the study area allowed inclusion of SA R image pairs with perpendicular baselines as long as about $500 \mathrm{~m}$ (1,640 ft) without adversely affecting the interferograms.

Phase shifts can be caused by the variation of atmospheric mass that is associated with different elevations. A digital elevation model is used in the interferogram generation process to reduce the topographic effects caused by elevation differences and to georeference the image. Phase shifts also can be caused by laterally variable atmospheric conditions, such as clouds or fog, because the non-uniform distribution of water vapor differentially slows the radar signal over an image, which causes differential phase shifts (Zebker and others, 1997). Clouds and fog can be assessed by using solar radiation or visible-spectrum satell ite data. Independent interferograms that do not share a common SA R image can be used to identify atmospheric artifacts. When apparent ground motion is detected in a single interferogram, or in a set of interferograms that share a common SA R image, the apparent motion is likely to be an artifact of atmospheric phase delay or another error source within the common SAR image. When the pixel-by-pixel range displacements of two or more interferograms are added to create a "stacked interferogram," a cloud in one particular SA R scene does not necessarily affect the total displacement measured by the stacked interferogram. For example, when two interferograms are generated from three SA R scenes, the area with a cloud in the common SAR image will have apparent increased range in the first interferogram and decreased range in the second interferogram. When these two interferograms are added (stacked) together, the equal and opposite apparent deformation will be cancelled out.

The type and density of ground cover also can affect interferogram quality. Densely forested areas are poor reflectors because the C-band radar signal, which has a wavelength of $56 \mathrm{~mm}(0.18 \mathrm{ft})$, is either absorbed or reflected from various canopy depths, which results in incoherent signals (shown as randomized colors on an interferogram). In contrast, sparsely vegetated areas and urban centers generally reflect coherent signals because bare ground, roads, and buildings have consistently uniform surfaces during at least some range of InSA R timespans. Certain land-use practices, such as the prevalent farming in the southern part of the Coachella Valley, cause incoherent areas in both the phase and amplitude components on interferograms because the tilling and plowing of farm fields causes relatively large and nonuniform ground-surface changes. Interferogram quality also is adversely affected by longer timespans between SA R scenes because there is more opportunity for nonuniform change in both urban and non-urban areas. The Coachella Valley is generally suitable for InSAR analysis because it is fairly flat, arid, and contains several urban centers; therefore, most of the aforementioned error sources are not substantial, except in agricultural areas, which appear incoherent.

There are two primary forms of interferometric processing: conventional and persistent scatterer (PS) InSAR. The difference between the conventional and the PS InSAR processing techniques is that the conventional technique computes the phase shifts at all pixels, whereas the PS technique computes the phase shifts at selected pixels. The selection of pixels for PS processing is based on the amplitude variance at each pixel in a selected set of SA R images (generally, at least 20 SA R images are used). Pixels that have relatively high variance in amplitude in the set of SAR images are filtered from the PS data set, resulting in a data set containing "stable" pixels. It is assumed that 


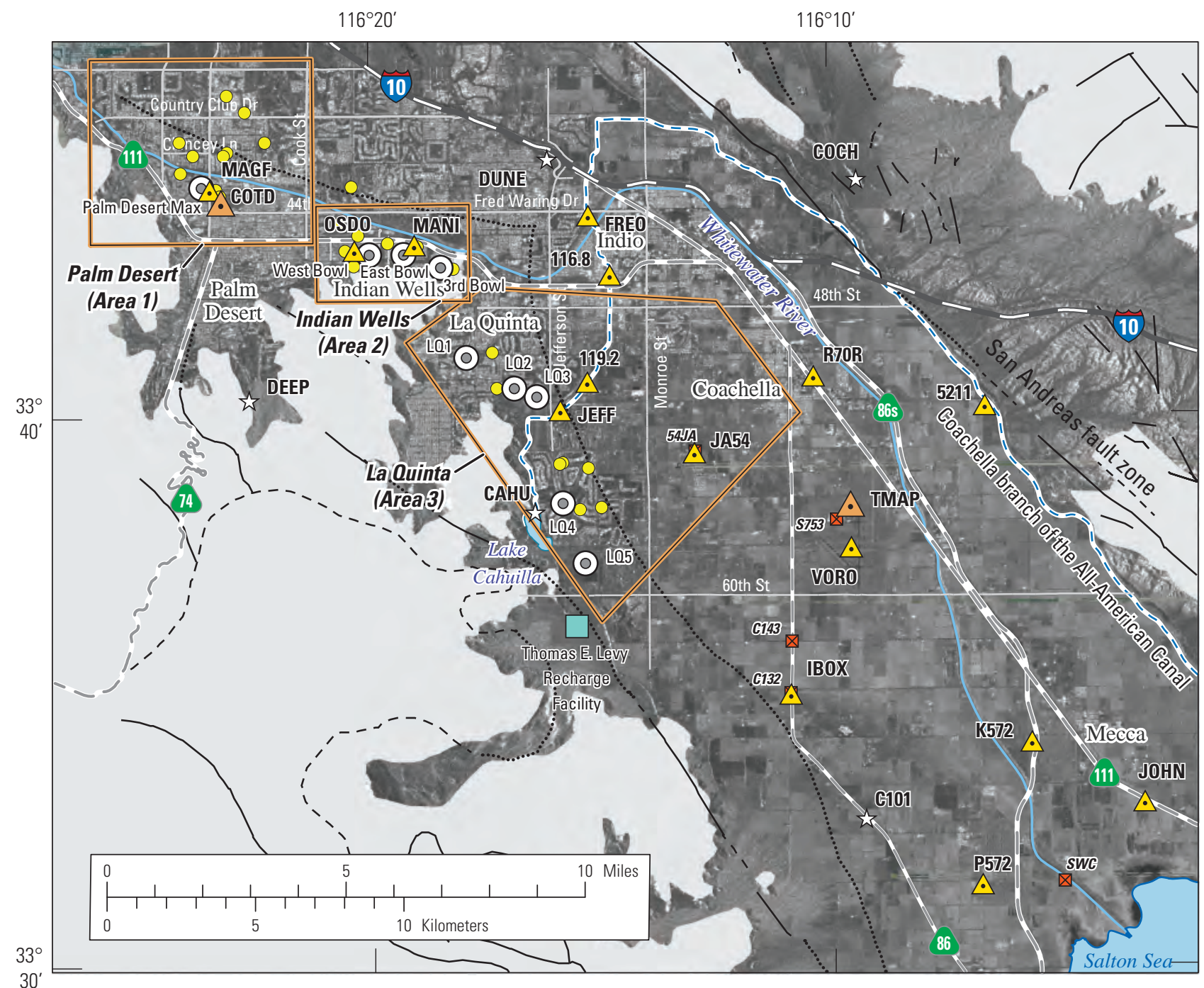

EXPLANATION
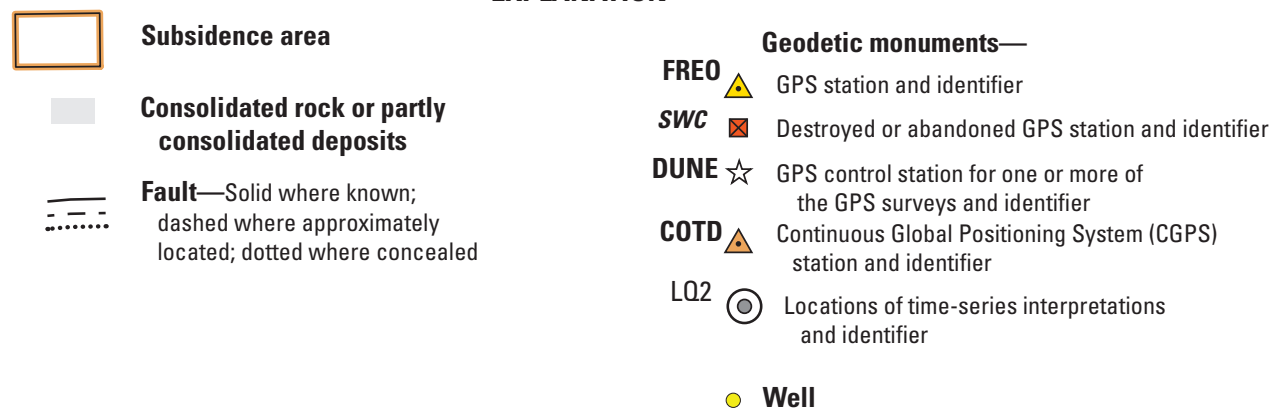

Figure 7. Land-surface features, consolidated rock, Global Positioning System (GPS) stations, two Continuous Global Positioning System (CGPS) stations, three areas of subsidence, and selected roads and wells, Coachella Valley, California.

the reflective properties in areas with high variance in amplitude have changed sufficiently so as to be unreliable for accurate measurement of el evation change (for example, active agricultural fields, construction or destruction of a building, high-traffic roads, and water-body surfaces). The PS InSA R processing is particularly advantageous in areas of agricultural use, such as those in the Coachella Valley. The suitable pixels generally contain low-traffic roads, undisturbed ground surfaces, farm houses, or other buildings. Pixels with high variability in phase, such as those within active agricultural fields, were excluded from the PS data set, which consequently contains high-pixel densities in urban and arid undeveloped regions and low-pixel densities in agricultural or rapidly developing areas. A differential-phase regression 
model was then calculated for selected interferograms, which defined a linear dependence of interferometric phase on the difference in satellite geometry between the two SA R images composing the interferogram. This linear relationship is used to determine a digital elevation model height correction factor (Werner and others, 2003; Strozzi and others, 2005).

Data from three European Space A gency (ESA) satellites were analyzed for this study. The ERS1 (European Remote Sensing 1) satellite was launched in July 1991 and began collecting SAR data in the Coachella Valley during 1992. ERS2 (European R emote Sensing 2), a nearly identical satellite to ERS1, was launched in A pril 1995 and orbited 1 day behind ERS1 (https://earth.esa.int, accessed February 8, 2013). A fter ERS1 was deactivated in 1996, ERS2 assumed its operational functions until late 2000, when equipment failures prevented further acquisition of reliable InSAR data. B ecause ERS1 and ERS2 utilized identical orbital parameters, their data can be combined to form interferograms, which are termed ERS data in this report. The multi-mission ENVISAT (Environmental Satellite) platform was launched in M arch 2002 and started collecting SA R data in the Coachella Valley during February 2003. ENV ISAT was fully operational until N ovember 2010, when a fuel-saving orbit change designed to extend its lifespan increased the platform's "wobble," which degraded the suitability of SA R acquisitions for interferometry. In 2012, it stopped communicating with ground tracking stations and was deactivated. These sidelooking SA R satellites orbited the Earth at an altitude of approximately $800 \mathrm{~km}$ (500 mi) and repeated orbital tracks every 35 days. Differences between the orbital geometries of ERS and ENVISAT prevent ERS SAR images from being combined with ENVISAT SAR images to form interferograms.

For this study, a total of 100 SAR images (49 ERS, and 51 EN V ISAT) between September 27, 1992, and September 19, 2010, were acquired and processed into 447 interferograms by using the PS InSA R technique. Of these, 49 ERS and 92 ENV ISAT interferograms between A pril 25, 1993, and September 19, 2010, were used for analysis. These 141 interferograms were selected on the basis of quality and the time spanned, which ranged from 35 days to 595 days (table 2). A subset of these 141 interferograms was also processed by using the conventional technique, one of which is presented in this report (fig. 8). There is a 3-year data gap in the 141 interferograms between N ovember 8, 2000, and 0 ctober 26, 2003, when ERS data were unsuitable for interferometry and before EN VISAT acquired suitable SA R data for the Coachella Vall ley.

Table 2. Interferograms interpreted for this report.

[See appendix A for selected interferograms used for the stacked and kriged interferogram shown in figure 8 A. Abbreviation: mm/dd/yyyy, month/day/year; SAR, Synthetic Aperture Radar]

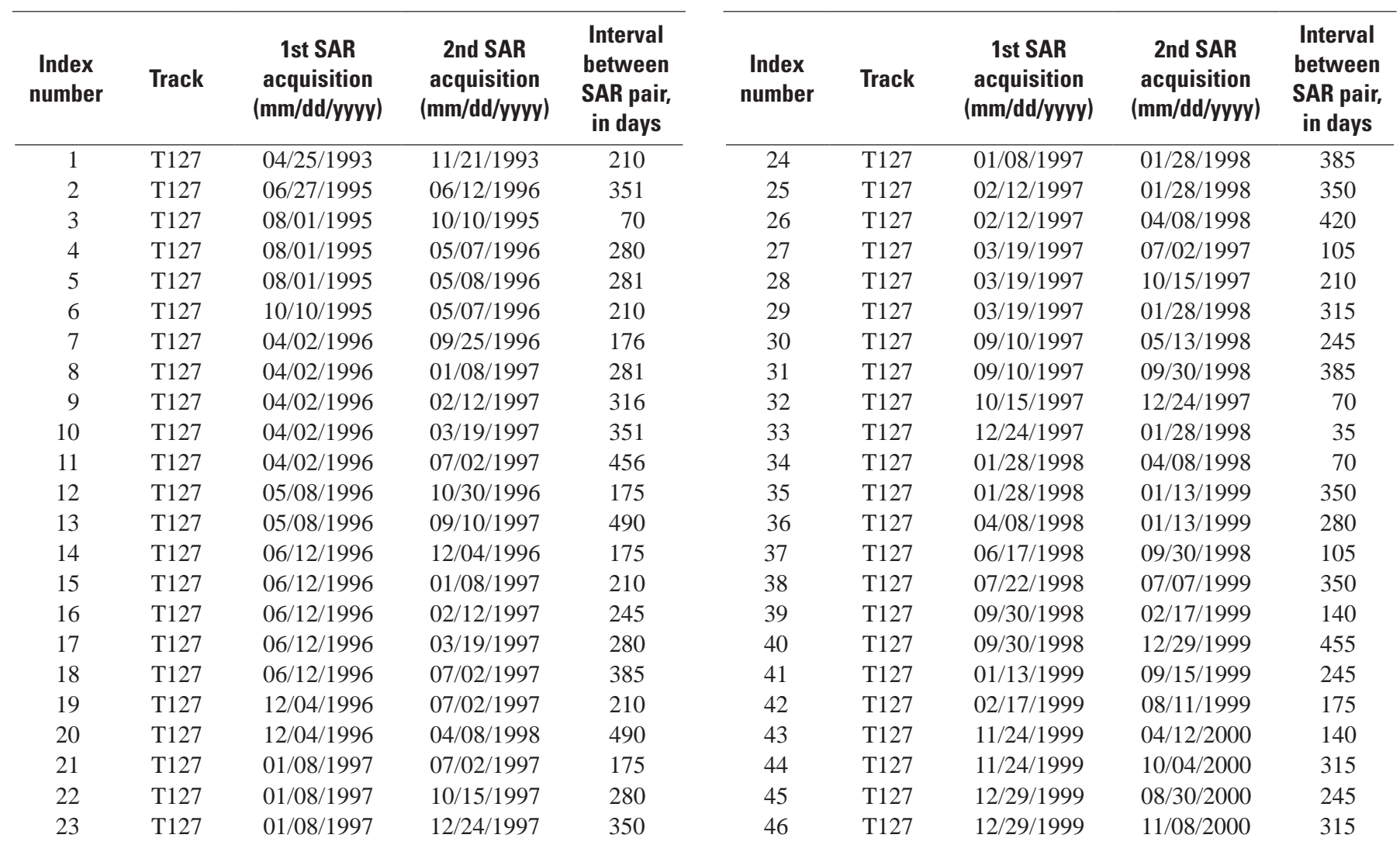


Table 2. Interferograms interpreted for this report.-Continued

[See appendix $A$ for selected interferograms used for the stacked and kriged interferogram shown in figure 8 A. Abbreviation: mm/dd/yyyy, month/day/year; SAR, Synthetic Aperture Radar]

\begin{tabular}{|c|c|c|c|c|c|c|c|c|c|}
\hline $\begin{array}{c}\text { Index } \\
\text { number }\end{array}$ & Track & $\begin{array}{c}\text { 1st SAR } \\
\text { acquisition } \\
\text { (mm/dd/yyyy) }\end{array}$ & $\begin{array}{c}\text { 2nd SAR } \\
\text { acquisition } \\
\text { (mm/dd/yyyy) }\end{array}$ & $\begin{array}{c}\text { Interval } \\
\text { between } \\
\text { SAR pair, } \\
\text { in days }\end{array}$ & $\begin{array}{l}\text { Index } \\
\text { number }\end{array}$ & Track & $\begin{array}{c}\text { 1st SAR } \\
\text { acquisition } \\
\text { (mm/dd/yyyy) }\end{array}$ & $\begin{array}{c}\text { 2nd SAR } \\
\text { acquisition } \\
\text { (mm/dd/yyyy) }\end{array}$ & $\begin{array}{l}\text { Interval } \\
\text { between } \\
\text { SAR pair, } \\
\text { in days }\end{array}$ \\
\hline 47 & T127 & $03 / 08 / 2000$ & $10 / 04 / 2000$ & 210 & 94 & T077 & 08/26/2007 & $11 / 04 / 2007$ & 70 \\
\hline 48 & T127 & $04 / 12 / 2000$ & $11 / 08 / 2000$ & 210 & 95 & Т 077 & $08 / 26 / 2007$ & $01 / 13 / 2008$ & 140 \\
\hline 49 & T127 & $06 / 21 / 2000$ & $10 / 04 / 2000$ & 105 & 96 & Т 077 & 08/26/2007 & $06 / 01 / 2008$ & 280 \\
\hline 50 & T077 & $10 / 26 / 2003$ & $06 / 27 / 2004$ & 245 & 97 & Т077 & $08 / 26 / 2007$ & $03 / 08 / 2009$ & 560 \\
\hline 51 & T077 & $10 / 26 / 2003$ & $11 / 14 / 2004$ & 385 & 98 & Т077 & 09/30/2007 & $02 / 17 / 2008$ & 140 \\
\hline 52 & T077 & $10 / 26 / 2003$ & 02/27/2005 & 490 & 99 & Т 077 & 09/30/2007 & 08/10/2008 & 315 \\
\hline 53 & T077 & $10 / 26 / 2003$ & $06 / 12 / 2005$ & 595 & 100 & Т077 & 09/30/2007 & $03 / 08 / 2009$ & 525 \\
\hline 54 & T077 & $11 / 30 / 2003$ & $05 / 23 / 2004$ & 175 & 101 & T 077 & 09/30/2007 & $04 / 12 / 2009$ & 560 \\
\hline 55 & T077 & $11 / 30 / 2003$ & $01 / 23 / 2005$ & 420 & 102 & Т077 & $11 / 04 / 2007$ & 03/23/2008 & 140 \\
\hline 56 & T077 & $05 / 23 / 2004$ & $01 / 23 / 2005$ & 245 & 103 & T077 & $11 / 04 / 2007$ & $04 / 27 / 2008$ & 175 \\
\hline 57 & T077 & $05 / 23 / 2004$ & 05/08/2005 & 350 & 104 & T077 & $11 / 04 / 2007$ & 06/01/2008 & 210 \\
\hline 58 & T077 & $05 / 23 / 2004$ & 07/17/2005 & 420 & 105 & T077 & $11 / 04 / 2007$ & $03 / 08 / 2009$ & 490 \\
\hline 59 & T077 & $06 / 27 / 2004$ & $11 / 14 / 2004$ & 140 & 106 & T077 & $11 / 04 / 2007$ & $05 / 17 / 2009$ & 560 \\
\hline 60 & T077 & $06 / 27 / 2004$ & 02/27/2005 & 245 & 107 & T077 & 12/09/2007 & $04 / 12 / 2009$ & 490 \\
\hline 61 & T077 & $06 / 27 / 2004$ & $06 / 12 / 2005$ & 350 & 108 & T077 & 01/13/2008 & $03 / 23 / 2008$ & 70 \\
\hline 62 & T077 & $06 / 27 / 2004$ & 08/21/2005 & 420 & 109 & T077 & $01 / 13 / 2008$ & $04 / 27 / 2008$ & 105 \\
\hline 63 & T077 & $06 / 27 / 2004$ & $02 / 12 / 2006$ & 595 & 110 & T077 & $01 / 13 / 2008$ & $06 / 01 / 2008$ & 140 \\
\hline 64 & T077 & 08/01/2004 & $04 / 03 / 2005$ & 245 & 111 & T077 & $01 / 13 / 2008$ & $03 / 08 / 2009$ & 420 \\
\hline 65 & T077 & 09/05/2004 & $04 / 03 / 2005$ & 210 & 112 & T077 & $01 / 13 / 2008$ & 05/17/2009 & 490 \\
\hline 66 & T077 & $11 / 14 / 2004$ & 08/21/2005 & 280 & 113 & T077 & $02 / 17 / 2008$ & $03 / 08 / 2009$ & 385 \\
\hline 67 & T077 & $11 / 14 / 2004$ & $02 / 12 / 2006$ & 455 & 114 & T077 & $02 / 17 / 2008$ & $04 / 12 / 2009$ & 420 \\
\hline 68 & T077 & $11 / 14 / 2004$ & 03/19/2006 & 490 & 115 & T077 & $02 / 17 / 2008$ & 05/17/2009 & 455 \\
\hline 69 & T077 & $11 / 14 / 2004$ & $05 / 28 / 2006$ & 560 & 116 & T077 & $03 / 23 / 2008$ & $03 / 08 / 2009$ & 350 \\
\hline 70 & T077 & $12 / 19 / 2004$ & $12 / 04 / 2005$ & 350 & 117 & Т077 & $03 / 23 / 2008$ & 05/17/2009 & 420 \\
\hline 71 & T077 & $12 / 19 / 2004$ & 03/19/2006 & 455 & 118 & Т077 & $03 / 23 / 2008$ & $08 / 30 / 2009$ & 525 \\
\hline 72 & T077 & $01 / 23 / 2005$ & $07 / 17 / 2005$ & 175 & 119 & Т 077 & $04 / 27 / 2008$ & 03/08/2009 & 315 \\
\hline 73 & T077 & $02 / 27 / 2005$ & 05/28/2006 & 455 & 120 & Т077 & $04 / 27 / 2008$ & 05/17/2009 & 385 \\
\hline 74 & T077 & 05/08/2005 & $04 / 23 / 2006$ & 350 & 121 & Т077 & $04 / 27 / 2008$ & 08/30/2009 & 490 \\
\hline 75 & T077 & $06 / 12 / 2005$ & $02 / 12 / 2006$ & 245 & 122 & Т 077 & 06/01/2008 & 03/08/2009 & 280 \\
\hline 76 & T077 & $06 / 12 / 2005$ & $05 / 28 / 2006$ & 350 & 123 & Т 077 & $06 / 01 / 2008$ & $05 / 17 / 2009$ & 350 \\
\hline 77 & T077 & $06 / 12 / 2005$ & $12 / 24 / 2006$ & 560 & 124 & Т 077 & $06 / 01 / 2008$ & 08/30/2009 & 455 \\
\hline 78 & T077 & 08/21/2005 & 11/19/2006 & 455 & 125 & Т077 & 06/01/2008 & $01 / 17 / 2010$ & 595 \\
\hline 79 & T077 & $08 / 21 / 2005$ & $12 / 24 / 2006$ & 490 & 126 & Т077 & $03 / 08 / 2009$ & $05 / 17 / 2009$ & 70 \\
\hline 80 & T077 & $12 / 04 / 2005$ & $03 / 19 / 2006$ & 105 & 127 & Т 077 & $03 / 08 / 2009$ & 08/30/2009 & 175 \\
\hline 81 & T077 & $12 / 04 / 2005$ & $11 / 19 / 2006$ & 350 & 128 & Т077 & 03/08/2009 & $01 / 17 / 2010$ & 315 \\
\hline 82 & T077 & $02 / 12 / 2006$ & $11 / 19 / 2006$ & 280 & 129 & Т 077 & 03/08/2009 & 05/02/2010 & 420 \\
\hline 83 & T077 & $02 / 12 / 2006$ & $12 / 24 / 2006$ & 315 & 130 & Т077 & $04 / 12 / 2009$ & $12 / 13 / 2009$ & 245 \\
\hline 84 & T077 & 03/19/2006 & $11 / 19 / 2006$ & 245 & 131 & Т077 & $04 / 12 / 2009$ & $01 / 17 / 2010$ & 280 \\
\hline 85 & T077 & $05 / 28 / 2006$ & $11 / 19 / 2006$ & 175 & 132 & Т 077 & 04/12/2009 & $02 / 21 / 2010$ & 315 \\
\hline 86 & T077 & $10 / 15 / 2006$ & 09/30/2007 & 350 & 133 & Т077 & $04 / 12 / 2009$ & 05/02/2010 & 385 \\
\hline 87 & T077 & $10 / 15 / 2006$ & $11 / 04 / 2007$ & 385 & 134 & T 077 & 05/17/2009 & 08/30/2009 & 105 \\
\hline 88 & T077 & $10 / 15 / 2006$ & 12/09/2007 & 420 & 135 & Т077 & 05/17/2009 & $01 / 17 / 2010$ & 245 \\
\hline 89 & T077 & $10 / 15 / 2006$ & $04 / 27 / 2008$ & 560 & 136 & Т077 & 08/30/2009 & $01 / 17 / 2010$ & 140 \\
\hline 90 & T077 & $10 / 15 / 2006$ & $06 / 01 / 2008$ & 595 & 137 & Т 077 & 08/30/2009 & 09/19/2010 & 385 \\
\hline 91 & T077 & $12 / 24 / 2006$ & $08 / 26 / 2007$ & 245 & 138 & Т077 & $11 / 08 / 2009$ & 09/19/2010 & 315 \\
\hline 92 & T077 & $12 / 24 / 2006$ & $01 / 13 / 2008$ & 385 & 139 & Т 077 & 01/17/2010 & 05/02/2010 & 105 \\
\hline \multirow[t]{2}{*}{93} & T077 & $12 / 24 / 2006$ & 03/23/2008 & 455 & 140 & Т077 & $01 / 17 / 2010$ & 09/19/2010 & 245 \\
\hline & & & & & 141 & Т077 & $02 / 21 / 2010$ & $05 / 02 / 2010$ & 70 \\
\hline
\end{tabular}


Sixteen of the most suitable interferograms (nine from ERS and seven from ENVISAT) were selected to construct a deformation time series from J une 27, 1995, to September 19, 2010 (table 2; appendix A). In addition to the 3-year data gap previously mentioned, there were four small time gaps and one small overlap totaling 210 days and 71 days, respectively. Combined, the gaps and overlap represented less than 5 percent of the total time series. The potential magnitude of deformation during these gaps was estimated for each pixel by averaging the deformation rate determined from the interferograms immediately before and after the gap, converting that rate to a magnitude for the period of the gap, and adding that magnitude to the time series. Similarly, the magnitude of excess deformation measured in the time series due to the overlap was estimated for each pixel by determining the deformation rate from one of the interferograms containing the overlap, converting that rate to a magnitude for the 71-day overlap, and subtracting that magnitude from the time series. D eformation within the 3-year gap was estimated by averaging the deformation rate determined from the 16 interferograms at selected pixels. The estimated deformation during the 3-year gap was added to the time series to more accurately represent the total deformation. B ecause of excessive temporal and spatial variation in rates throughout the valley, how ever, the estimated deformation over the 3-year gap was not added to the stacked (and kriged) interferogram shown in figure $8 \mathrm{~A}$.

\section{Interferometric Synthetic Aperture Radar Detection of Land Subsidence}

The interferograms processed for the Coachella Valley showed substantial land-surface-elevation changes and indicated that land subsided between 1993 and 2010 in at least three areas: Palm D esert (area 1); Indian Wells (area 2); and La Quinta (area 3), which includes parts of the Coachella branch of the All-A merican Canal (fig. 7). These three areas were also identified in previous reports (Sneed and others, 2001; 2002; Sneed and B randt, 2007). The interferograms indicated that much of the study area in the Coachella Valley subsided (fig. 8) less than the areas of land subsidence discussed in the following sections.

\section{The Palm Desert Area (Area 1)}

A subsidence signal was detected in the Palm Desert area in all of the interferograms for A pril 25, 1993-September 19, 2010. The part of the signal that had the largest magnitude is nearly circular and centered about $1 \mathrm{~km}(0.6 \mathrm{mi})$ north of Fred Waring Drive and $1 \mathrm{~km}(0.6 \mathrm{mi})$ east of the intersection of B ob Hope Drive and Hwy 111 (figs. 7, 9); in longer-term interferograms, it is as large as about $2 \mathrm{~km}$ (1.2 mi) in diameter and has an area of about $4 \mathrm{~km}^{2}\left(1.5 \mathrm{mi}^{2}\right.$; figs. $8,9 B, 9 C)$. This part of the signal is approximately bounded by Clancey Lane on the north, Fred Waring Drive on the south, Highway 111 and B ob Hope on the west, and M onterey Avenue on the east, where golf course and urban land use predominate (figs. 7, 9). The part of the signal that is smaller in magnitude extends to the north and east and has a pronounced northwest to southeast el ongation (figs. 8, 9B, 9C). The extent of this part of the signal is less in interferograms representing shorter periods (for example, see fig. $A 4$ ) than interferograms representing longer periods (figs. 8, 9B, 9C) and can extend to the northwest, where Frank Sinatra D rive intersects the W hitewater River channel, to the north beyond Country Club Drive, and to the east as far as Cook Street (figs. 7, 9). The San J acinto and Santa Rosa M ountains, which outcrop consolidated rock, could act as barriers to subsidence farther to the south and southwest ( figs. 7, 8, 9). The extent of subsidence terminates abruptly northeast of Palm D esert, forming a northwest to southeast trending lineament (figs. 9B, 9C). The nature of this lineament and the differential subsidence across it are discussed in the section "Correlation of L and Subsidence, Groundwater Levels, Geologic Structures, and Fine-Grained Deposits." A lack of barriers to the northwest and southeast could explain the pronounced el ongation of the subsidence signal in these directions. The maximum subsidence magnitude was about $600 \mathrm{~mm}$ (1.97 ft) between J une 27, 1995, and September 19, 2010 (fig. 10A). The average subsidence rate increased from about $39 \mathrm{~mm} / \mathrm{year}$ $(0.13 \mathrm{ft} / \mathrm{yr})$ during $1995-2000$ to about $45 \mathrm{~mm} / \mathrm{year}(0.15 \mathrm{ft} / \mathrm{yr})$ during 2003-10. 


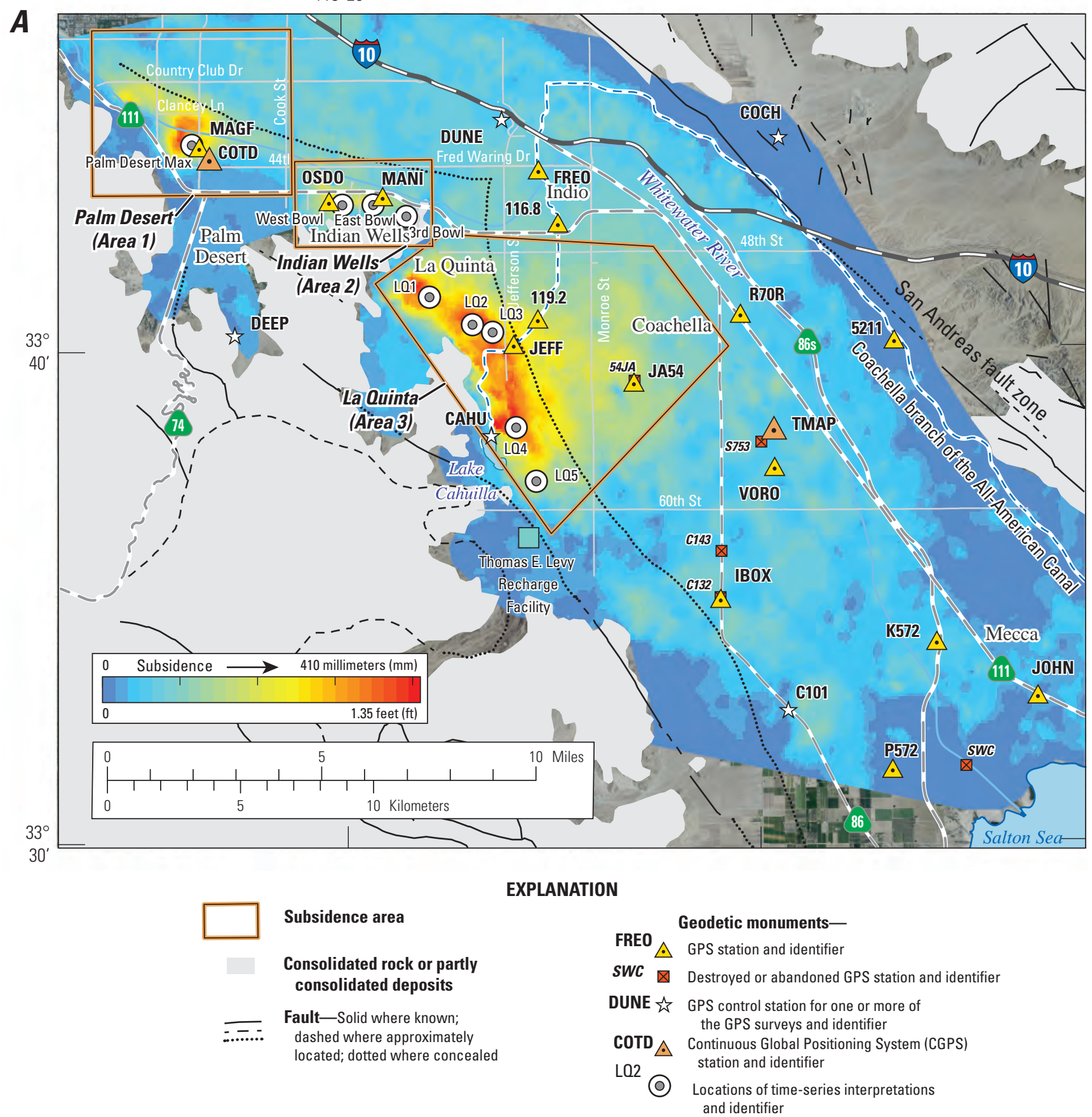

Figure 8. Areas of subsidence, consolidated rock, Global Positioning System (GPS) stations, and two Continuous GPS (CGPS) stations in the Coachella Valley, California, for $A$, June 27, 1995-September 19, 2010 (excludes November 8, 2000-November 30, 2003), as shown on a stacked and kriged interferogram; and $B$, June 1, 2008-March 8, 2009, as shown on a conventional interferogram (black areas indicate incoherent InSAR data). 
B

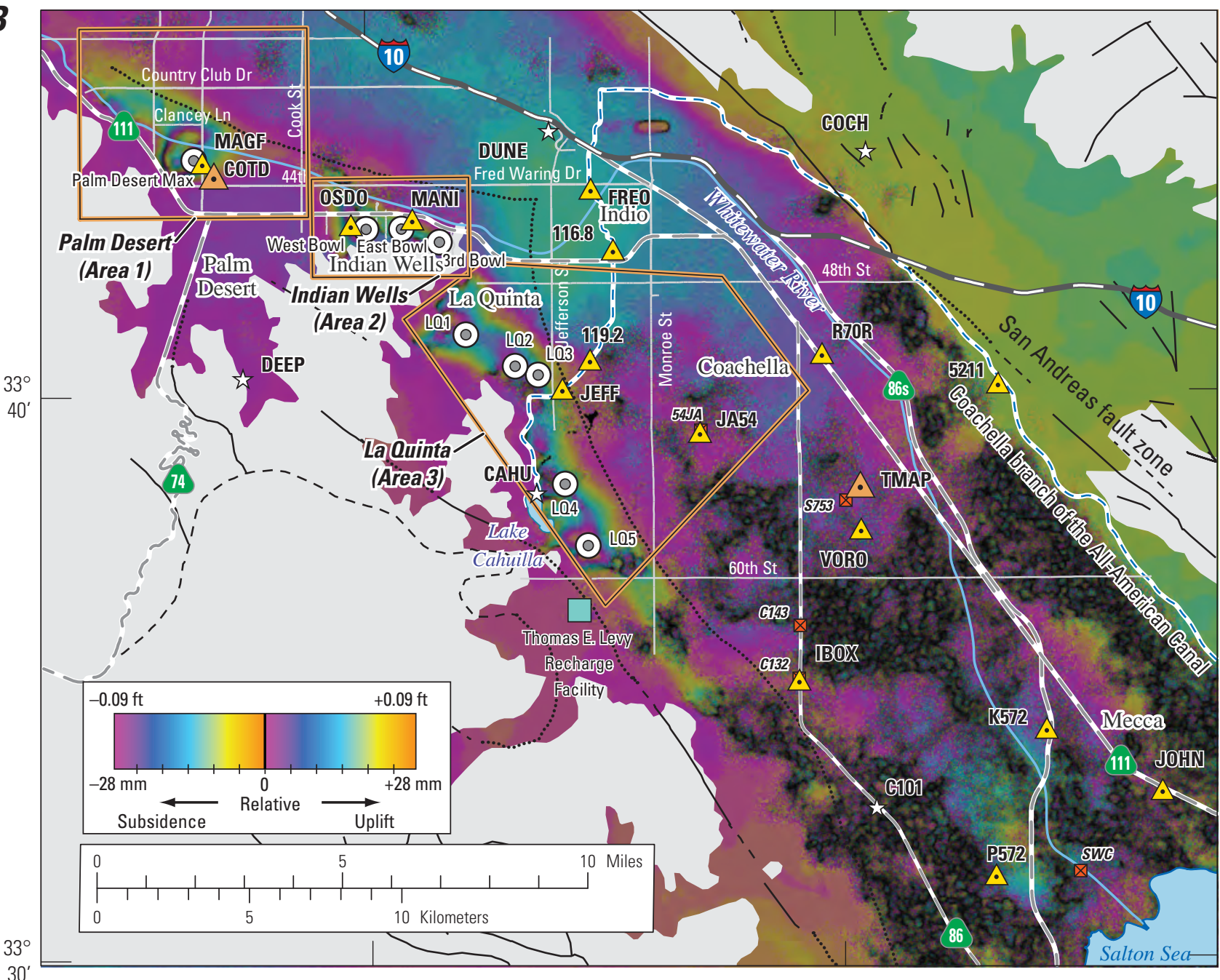

$30^{\prime}$

\section{EXPLANATION}

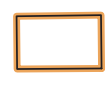

Subsidence area

Consolidated rock or partly consolidated deposits

Fault-Solid where known;
dashed where approximately located; dotted where concealed

\author{
FREO Geodetic monuments- \\ $\triangle$ GPS station and identifier \\ SWC $\square$ Destroyed or abandoned GPS station and identifier \\ DUNE 2 GPS control station for one or more of \\ the GPS surveys and identifier \\ COTD $\triangle$ Continuous Global Positioning System (CGPS) \\ station and identifier \\ LO2 \\ (O) Locations of time-series interpretations \\ and identifier
}

Figure 8. -Continued 

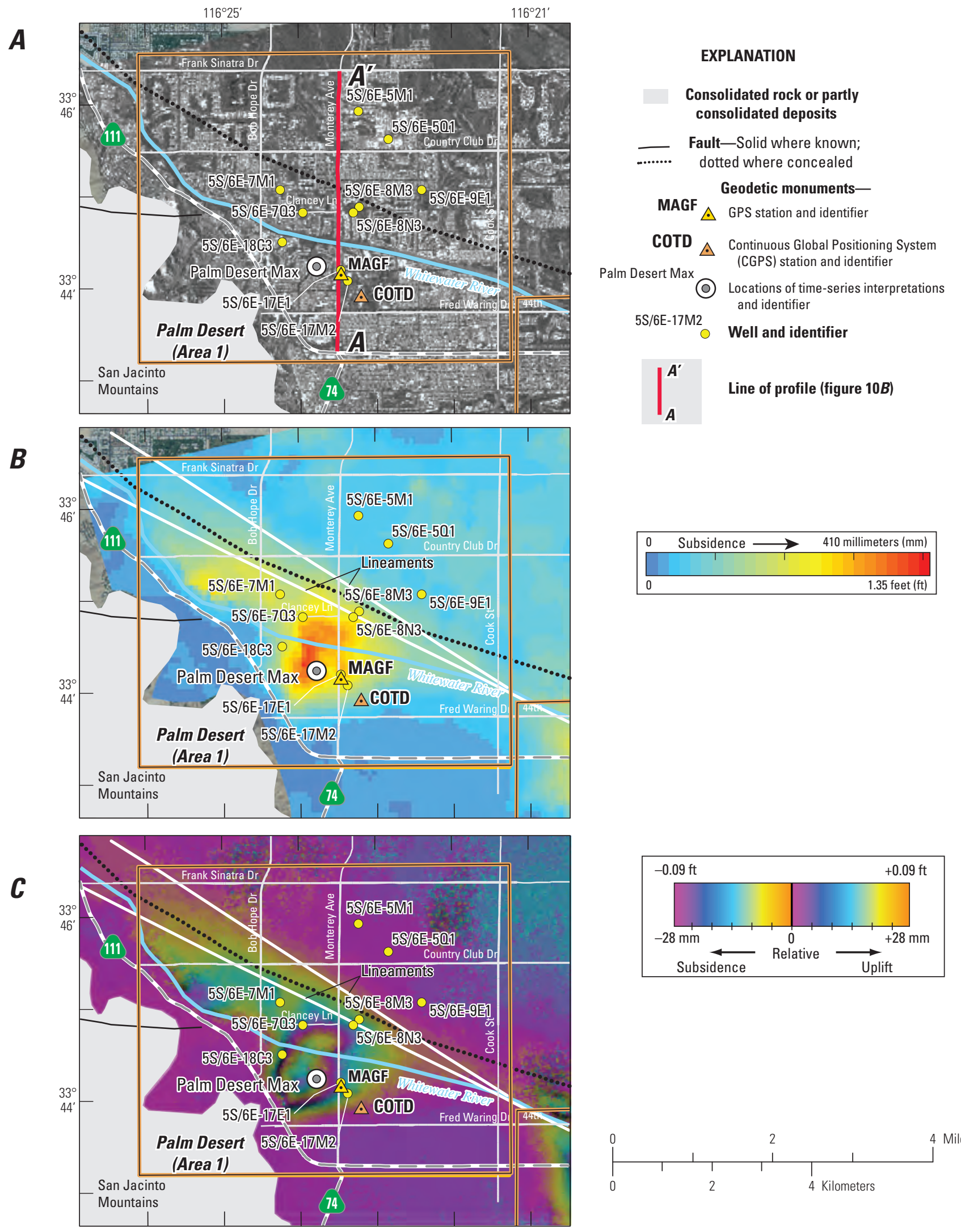

Figure 9. Palm Desert subsidence area (Area 1), Coachella Valley, California, showing one Global Positioning System (GPS) station, one Continuous Global Positioning System (CGPS) station, consolidated rock, and selected roads and wells overlain on $A$, an amplitude image showing land-surface features; $B$, a stacked and kriged interferogram depicting subsidence during June 27, 1995-September 19, 2010 (excluding November 8, 2000-November 30, 2003); and C, a conventional interferogram depicting subsidence during June 1, 2008March 8, 2009. 

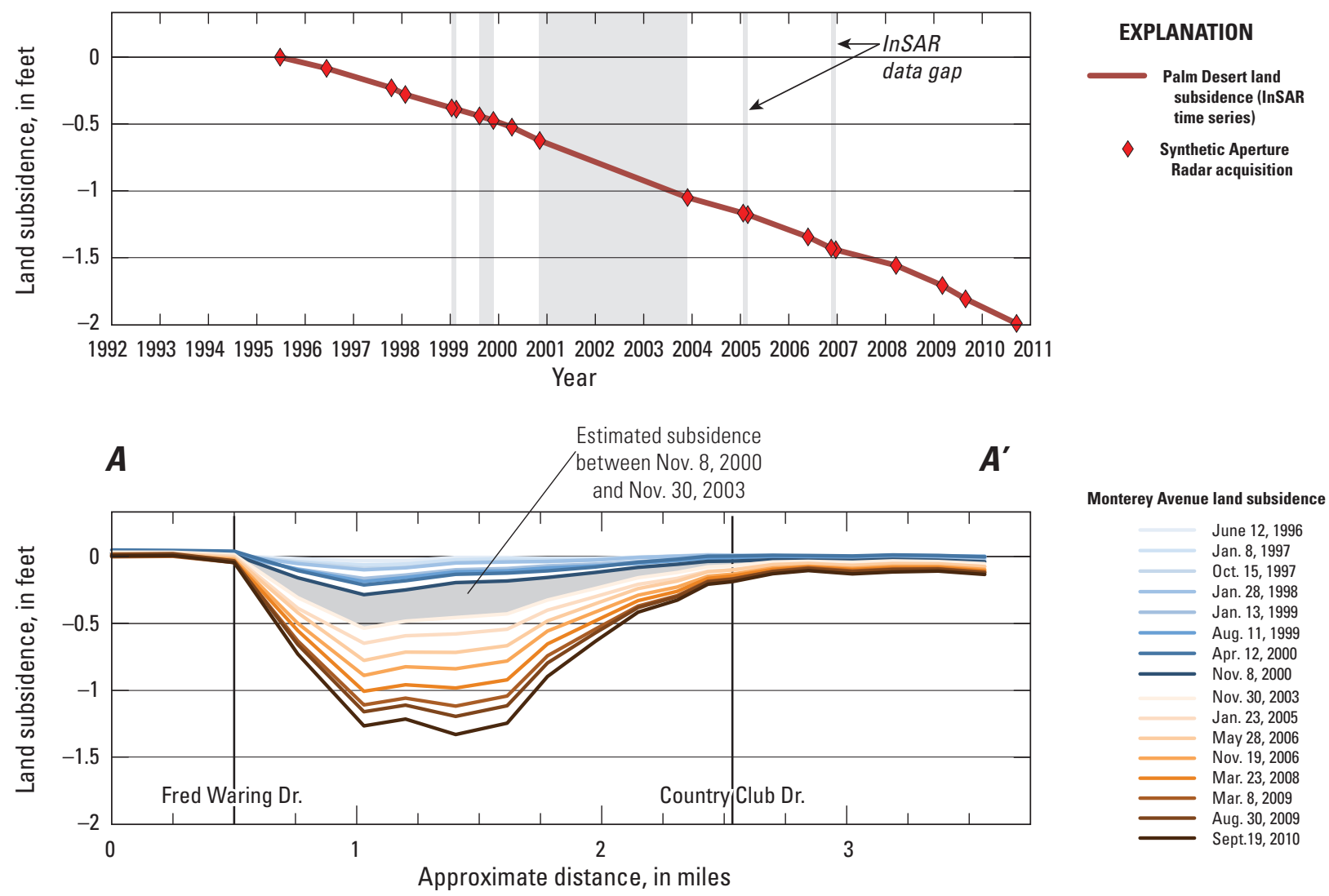

Figure 10. Land subsidence in the Palm Desert area (Area 1), Coachella Valley, California, during June 27, 1995-September 19, 2010, derived from interferograms shown in appendix $A$ (including estimated subsidence for November 8, 2000-November 30, 2003): $A$, time series for the location of maximum subsidence; and $B$, profile along Monterey Avenue. See figure $9 A$ for profile location.

\section{The Indian Wells Area (Area 2)}

In the Indian Wells area, two distinct subsidence signals were detected, termed the western bowl and the eastern bowl; additionally, there is a smaller and less distinct third bowl. All of the interferograms showed subsidence in the Indian Wells area for A pril 25, 1993-September 19, 2010. The western bowl is centered approximately $0.5 \mathrm{~km}(0.3 \mathrm{mi})$ south of $\mathrm{Hwy} 111$ and $0.3 \mathrm{~km}(0.2 \mathrm{mi})$ east of Eldorado Drive (figs. 7,11$)$ and is el ongated northwest-southeast (figs. 8, 11B, 11C). The eastern bowl is centered about $0.7 \mathrm{~km}(0.4 \mathrm{mi})$ south of Hwy 111 and about $1.3(0.8 \mathrm{mi})$ $\mathrm{km}$ southeast of the west bowl (figs. 7,11 ) and is elongated east-west (figs. 8, 11B, 11C). A third bowl is centered about $0.6 \mathrm{~km}(0.4 \mathrm{mi})$ south of $\mathrm{H}$ wy 111 and about $1.3 \mathrm{~km}(0.8 \mathrm{mi})$ southeast of the east bowl (figs. 7,11 ) and is approximately circular (for example, see fig. A12). Similar to the Palm Desert subsidence area, the land use in and adjacent to the three bowls is predominantly golf courses and urban land use. The interferograms analyzed for this study generally showed three distinct bowls separated by areas of lower subsidence magnitudes (for example, see fig. A12) or showed the third bowl as an extension of the eastern bowl (for example, see fig. A3). Together, the three bowls make up an area of about $8 \mathrm{~km}^{2}\left(3 \mathrm{mi}^{2}\right)$. The extent of subsidence terminates abruptly on the northeast extents of both the west and east bowls, forming a northwest to southeast trending lineament, which closely aligns with the previously discussed lineament that terminates the northeast extent of the Palm Desert subsidence area (figs. 8B, 11C). A dditional northwest to southeast lineaments were observed near the western margin of the west bowl and between the west and east bowls (fig. 11C). A time series between J une 27, 1995, and September 19, 2010, indicated a maximum subsidence magnitude of about $480 \mathrm{~mm}(1.57 \mathrm{ft})$, $380 \mathrm{~mm}$ ( $1.25 \mathrm{ft})$, and $220 \mathrm{~mm}(0.72 \mathrm{ft})$ for the west, east, and third bowls, respectively (fig. 12A). Average subsidence rates for 2003-10 were similar to average rates for 1995-2000 for the west and east bowls; the average rates for the third bowl increased from the earlier to the later period. The west bowl subsidence rates increased slightly from about 33 to $35 \mathrm{~mm} / \mathrm{yr}$ ( 0.11 to $0.11 \mathrm{ft} / \mathrm{yr}$ ); the east bowl subsidence rates increased slightly from about 25 to $27 \mathrm{~mm} / \mathrm{yr}$ ( 0.08 to $0.09 \mathrm{ft} / \mathrm{yr})$; and the third bowl subsidence rates increased from 14 to $19 \mathrm{~mm} / \mathrm{yr}$ (0.05 to $0.06 \mathrm{ft} / \mathrm{yr}$ ). 

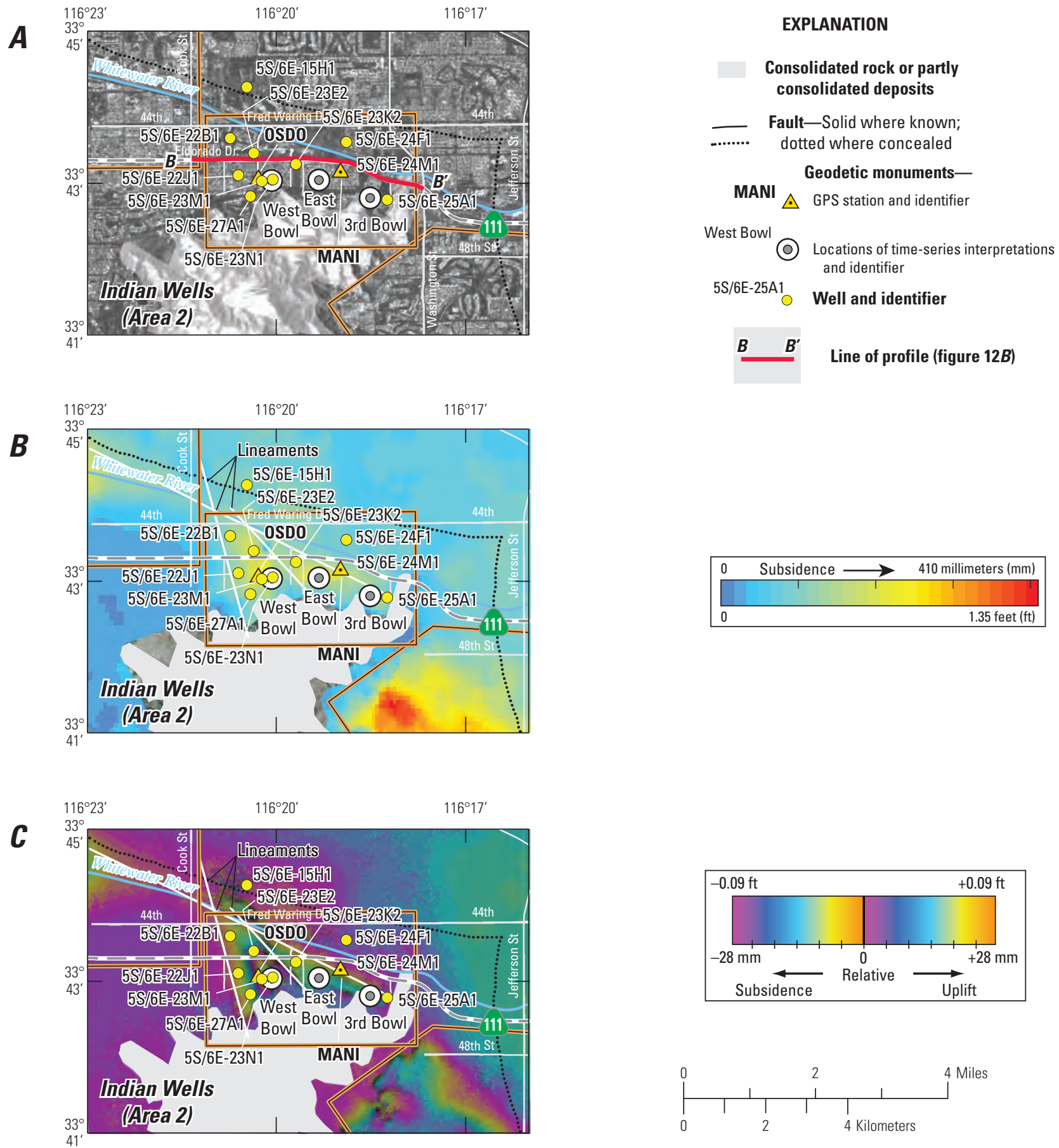

Figure 11. Indian Wells subsidence area (Area 2), Coachella Valley, California, showing two Global Positioning System (GPS) stations, consolidated rock, and selected roads and wells overlain on $A$, an amplitude image showing land-surface features; $B$, a stacked and kriged interferogram depicting subsidence during June 27, 1995-September 19, 2010 (excluding November 8, 2000-November 30, 2003); and $C$, a conventional interferogram depicting subsidence during June 1, 2008-March 8, 2009. 
$\boldsymbol{A}$

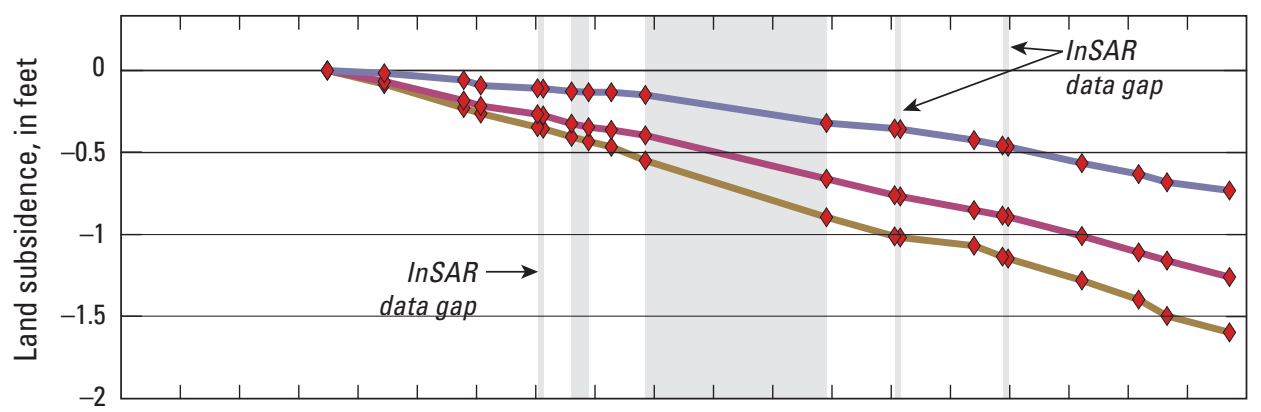

19921993199419951996199719981999200020012002200320042005200620072008200920102011

Year
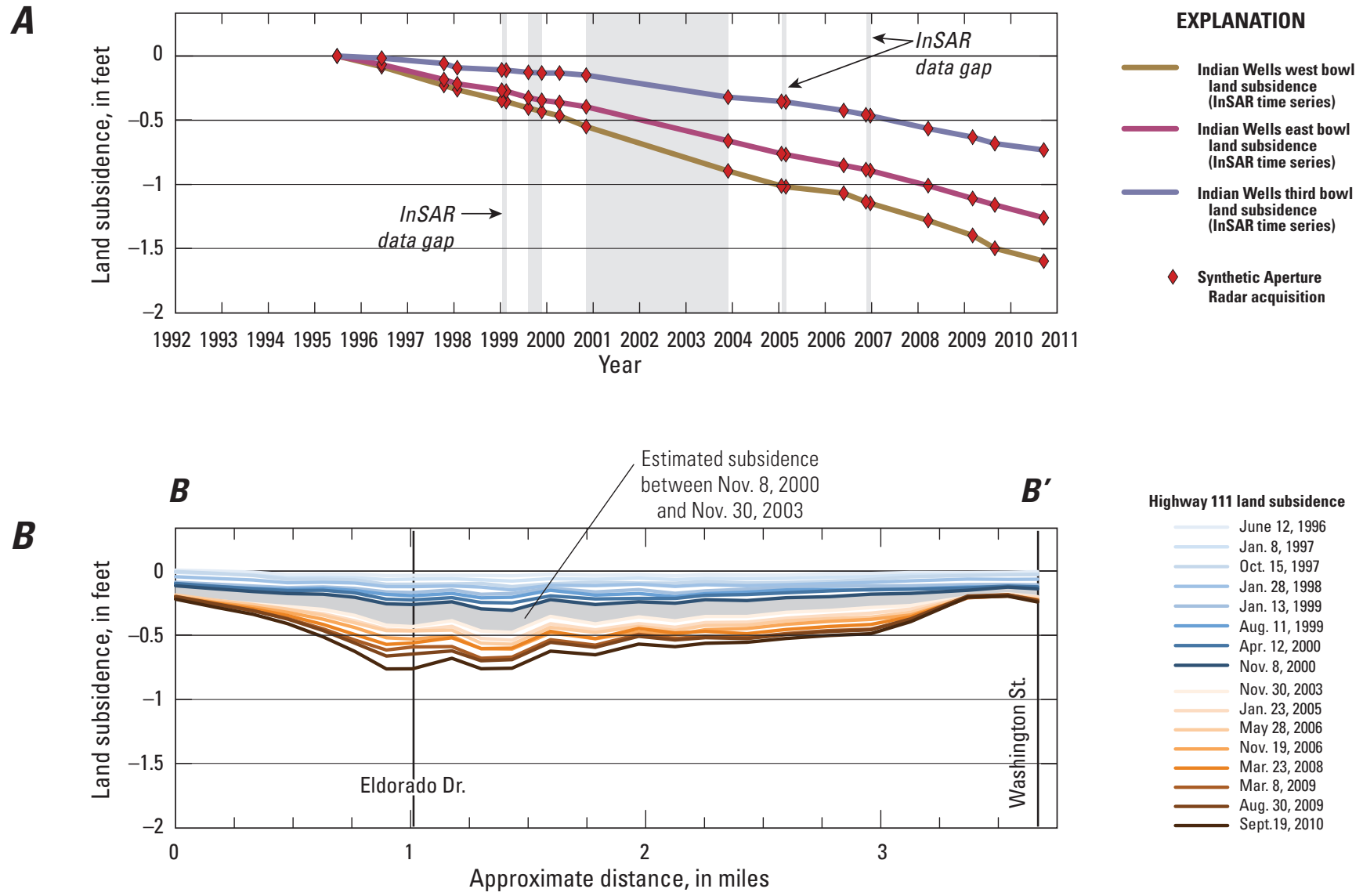

Figure 12. Subsidence in the Indian Wells area (Area 2), Coachella Valley, California, during June 27, 1995-September 19, 2010, derived from interferograms shown in appendix $A$ (including estimated subsidence for November 8, 2000-November 30, 2003): $A$, time series for three locations of maxima; and $B$, profile along Highway 111. See figure 11A for profile location.

\section{Land Subsidence near La Quinta, Including Parts of the Coachella Branch of the All-American Canal (Area 3)}

A $n$ area of subsidence was detected in the $L$ a Q uinta area in all of the interferograms for A pril 25, 1993-September 19, 2010. The results of the PS InSA R technique indicated that this subsidence area was larger than defined in previous reports (Sneed and others, 2001; 2002; Sneed and B randt, 2007), covering about $85 \mathrm{~km}^{2}\left(33 \mathrm{mi}^{2}\right)$ and extending eastward toward the agriculturally active center of the Coachella Valley, which subsided at least $60 \mathrm{~mm}(0.20 \mathrm{ft})$ between June 27, 1995, and September 19, 2010; about half of this area $\left(45 \mathrm{~km}^{2}\right.$ or $\left.17 \mathrm{mi}^{2}\right)$ subsided at least $120 \mathrm{~mm}(0.39 \mathrm{ft}$; figs. $7,8 \mathrm{~A}, 13 \mathrm{~A}, 13 \mathrm{~B})$. The subsidence magnitudes for these large areas are given as minimum values because (1) the reported magnitudes exclude deformation that probably occurred during the 2000-03 InSA R data gap, as indicated by GPS-measured subsidence at J A 54 during 2000-05 (table 1; fig. 4I), and (2) kriged InSAR data tend to result in conservative subsidence magnitudes compared to the unkriged InSA R data. The most rapidly subsiding part of this large area, corresponding to the "La Quinta subsidence area" as defined in previous reports (Sneed and others, 2001; 2002; Sneed and B randt, 2007), is about $10 \mathrm{~km}(6.2 \mathrm{mi})$ in length by about $3 \mathrm{~km}(1.9 \mathrm{mi})$ in width and trends northwest to southeast (figs. $8,13 B, 13 C$ ). This rapidly subsiding area is approximately bounded by Avenue 48 (if extended westward) on the north, Avenue 60 (if extended westward) on the south, the Santa R osa M ountains on the west, and streets varying from J efferson Street to M onroe Street on the east (figs. 7, 13). B ecause this is a large area of subsidence, time series plots of subsidence were produced for five selected locationsfour that generally coincided with maxima and one near the southern extent of the subsidence area (figs. 7, 8, 13). The time series for the four maxima locations were all within golf courses and indicated that subsidence ranged from about $465 \mathrm{~mm}(1.53 \mathrm{ft})$ to about $600 \mathrm{~mm}(1.97 \mathrm{ft})$ for J une 27, 1995September 19, 2010 (fig. 14A). The time series for the fifth location, near the southern extent of the L a Quinta subsidence area and near the Thomas E. L evy R echarge Facility, showed about $225 \mathrm{~mm}(0.74 \mathrm{ft}$ ) of subsidence (fig. $14 \mathrm{~A}$ ). Comparison of subsidence rates computed for 1995-2000 and for 2003mid-2009 showed the average subsidence rates were fairly steady at three of the locations and increased at the other two. A t L Q 1, L Q 4, and LQ 5, subsidence rates were fairly steady 


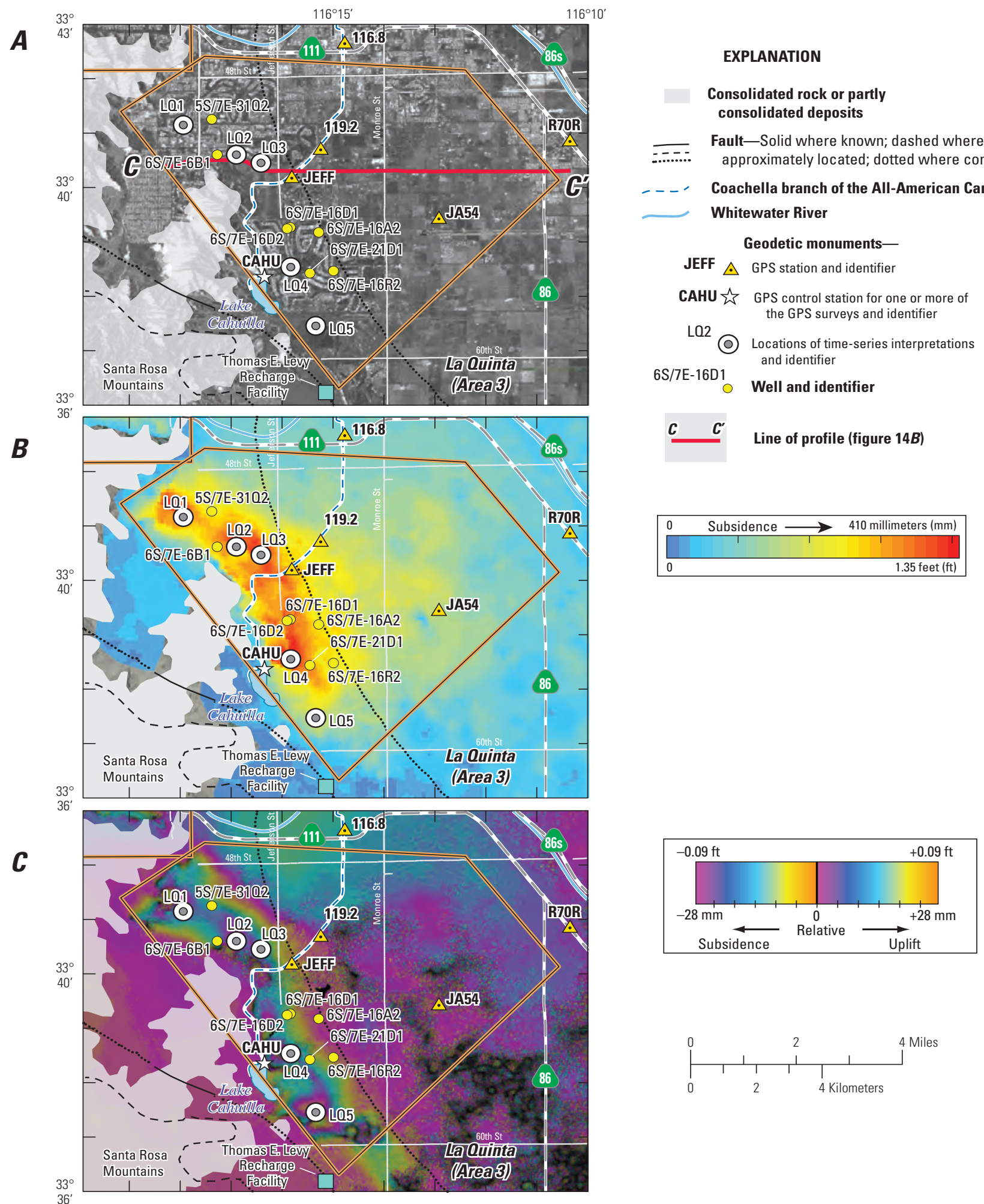

Figure 13. La Quinta subsidence area (Area 3), Coachella Valley, California, showing six Global Positioning System (GPS) stations, consolidated rock, and selected roads and wells overlain on $A$, an amplitude image showing land-surface features; $B$, a stacked and kriged interferogram depicting subsidence during June 27, 1995-September 19, 2010 (excluding November 8, 2000 and November 30, 2003) and subsidence time series for five selected locations; and $C$, a conventional interferogram depicting subsidence during June 1 , 2008-March 8, 2009 (black areas indicate incoherent InSAR data). 
$\boldsymbol{A}$

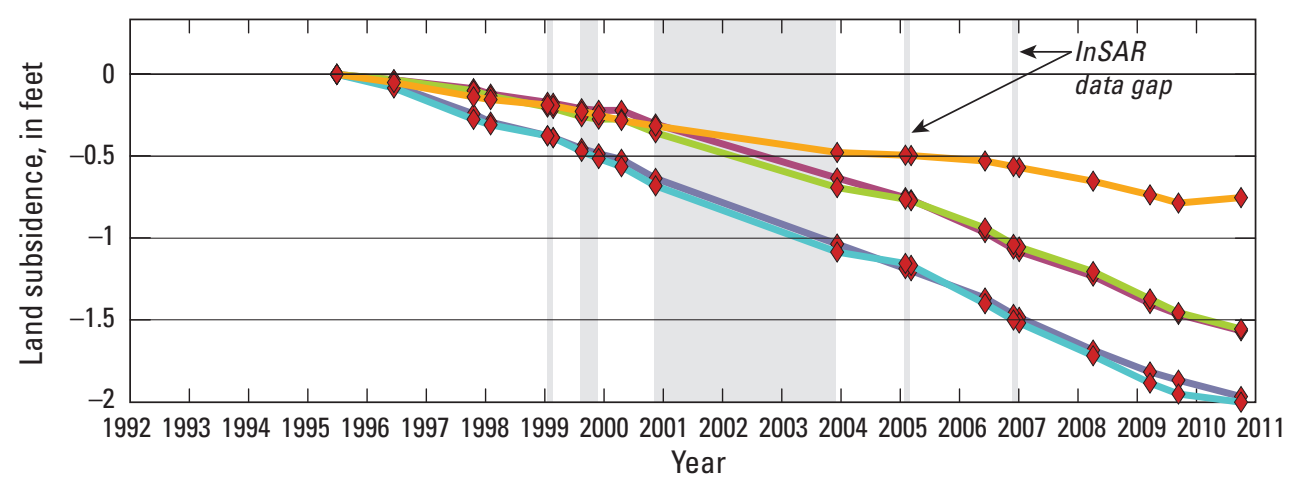

EXPLANATION

La Quinta InSAR time series

$\longrightarrow$ L01

$\longrightarrow \quad \mathrm{LO2}$

$\longrightarrow \quad \mathrm{LO3}$

204
$-\quad 205$

$\checkmark$ Synthetic Aperture Radar acquisition

Year

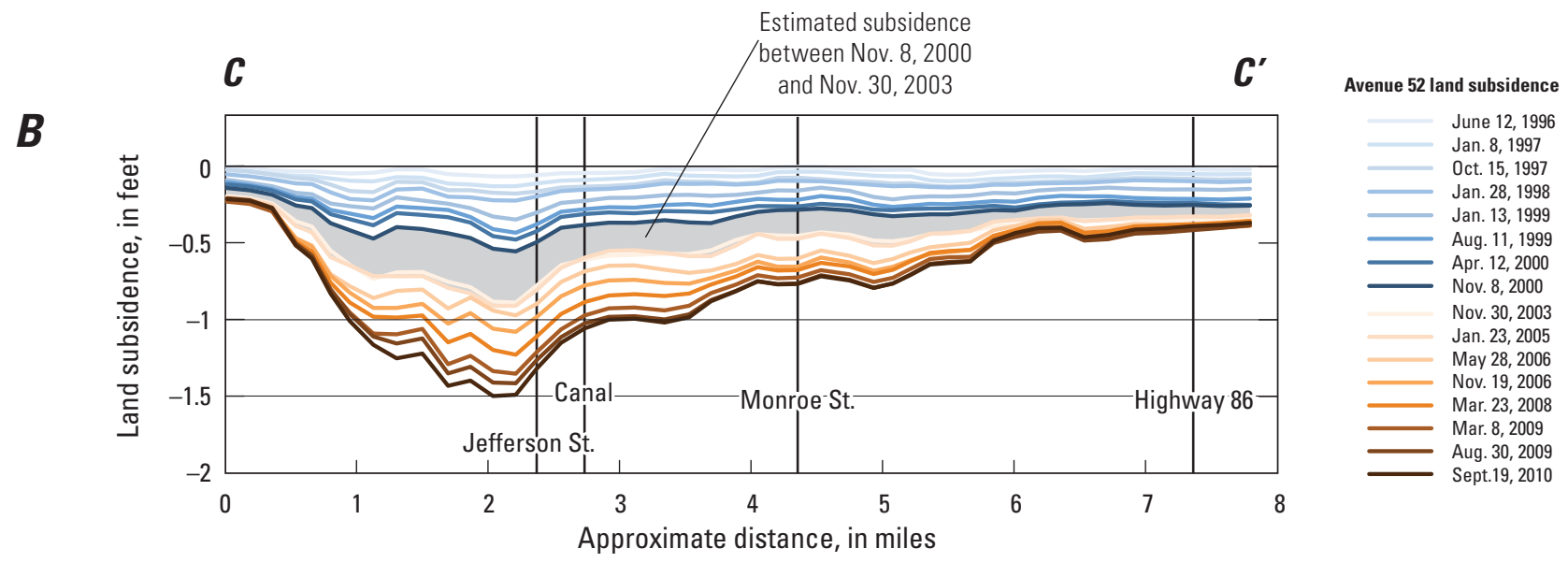

Figure 14. Subsidence in the La Quinta subsidence area (Area 3), Coachella Valley, California, during June 27, 1995-September 19, 2010, derived from interferograms shown in appendix $A$ (including estimated subsidence for November 8, 2000-November 30, 2003): $A$, time series for five selected locations (four are maxima) during June 27, 1995-September 19, 2010; and $B$, profile along Avenue 52. See figure $13 A$ for profile location.

at about 37,39 , and $17 \mathrm{~mm} / \mathrm{yr}(0.12,0.13$, and $0.06 \mathrm{ft} / \mathrm{yr})$, respectively, for both periods. Subsidence rates increased from 22 to $39 \mathrm{~mm} / \mathrm{yr}$ ( 0.07 to $0.13 \mathrm{ft} / \mathrm{yr}$ ) at LQ2 and increased 24 to $37 \mathrm{~mm} / \mathrm{yr}(0.08$ and $0.12 \mathrm{ft} / \mathrm{yr}$ ) at LQ3. Subsidence rates slowed during mid-2009-2010 to about $28 \mathrm{~mm} / \mathrm{yr}$ ( $0.09 \mathrm{ft} / \mathrm{yr}$ ) at LQ 1, LQ2, and LQ3 and to about $14 \mathrm{~mm} / \mathrm{yr}$ $(0.04 \mathrm{ft} / \mathrm{yr})$ at LQ 4; LQ 5 uplifted at a rate of about $9 \mathrm{~mm} / \mathrm{yr}$ (0.03 ft/yr) during mid-2009-2010.

L ong-term subsidence al ong the Coachella branch of the All-A merican Canal was analyzed in detail because subsidence has caused sags that adversely affected flow, loss of freeboard, and misalignment of the water surface and the concrete liner in some areas, which prompted the CV W D to consider canal realignment (http://www.cvwd.org/news/ fww/2012_spring_FWW.pdf, accessed J uly 29, 2013). The effects of a sag in a channel profile are increased flow velocity in the upstream end, decreased velocity in the middle, and loss of flow capacity immediately downstream of the sag. If the sag is deep, the height of the channel at the sag might not be sufficient to maintain flow capacity downstream of the subsided reach.

A subsidence profile consisting of 36 selected pixels covering about $43 \mathrm{~km}$ ( $27 \mathrm{mi}$ ) of the canal from Lake Cahuilla was constructed to illustrate the differential subsidence al ong the canal (fig. 15). The time series for J une 27, 1995, to September 19, 2010, indicated the maximum subsidence al ong the canal (about $410 \mathrm{~mm}$ or $1.35 \mathrm{ft}$ ) occurred less than $5 \mathrm{~km}$ (3.1 mi) from Lake Cahuilla, just west of the canal intersection with J efferson Street (fig. 15). There was minimal subsidence at distances of about $20 \mathrm{~km}(12.4 \mathrm{mi})$ or more from Lake Cahuilla, where the canal courses al ong the foothills of the Little San B ernardino M ountains and the Cottonwood M ountains on the east side of the valley. 


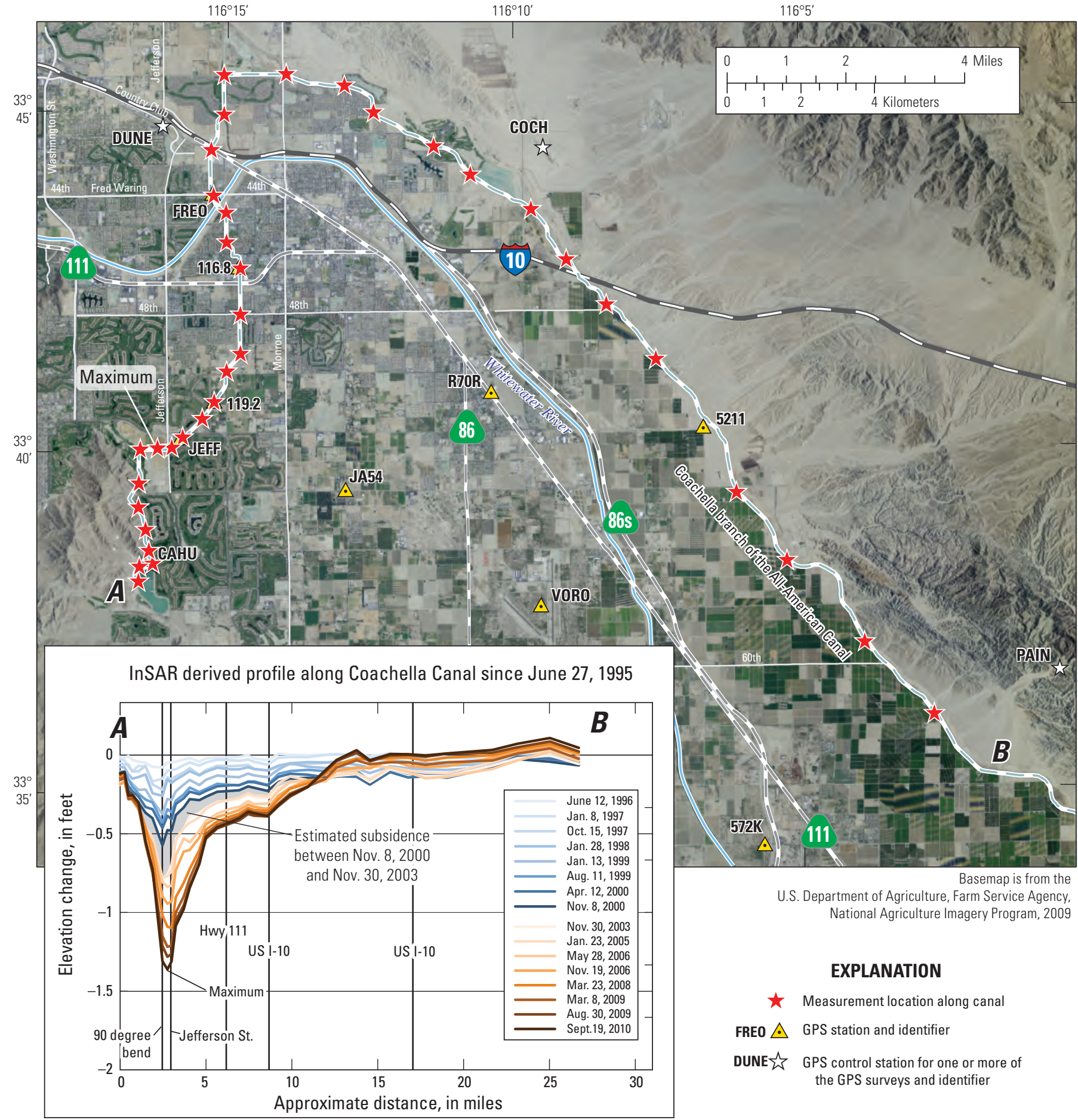

Figure 15. Location of subsidence profile and selected locations along the Coachella branch of the All-American Canal, and graph showing subsidence magnitudes along the canal profile derived from selected interferograms shown in appendix $A$. 


\section{Groundwater Levels near the Three Subsiding Areas Detected by Using Interferometric Synthetic Aperture Radar}

A II three areas where substantial subsidence was detected by using InSA R - Palm Desert, Indian Wells, and La Quintawere in or near areas where groundwater pumping generally caused seasonal groundwater-level fluctuations and longer-term groundwater-level declines during 1993-2010 (figs. 16, 17). Water levels measured in the late 2000s in many wells in the Palm Desert (figs. 16A, 16B, 17A, 17B), Indian Wells (figs. 16C, 16D, 17C, 17D), and La Quinta (figs. 16E, 17E) areas were at the lowest levels in their recorded histories (fig. 17). However, water-levels in and near the L a Quinta area, which had declined for decades, stabilized in mid-2008 and, subsequently, recovered (figs. 4M, 4N, 4O, $4 P, 4 Q, 4 R, 4 \mathrm{~S}, 16 E, 17 E)$. The stabilization and recovery of water levels in this area coincided with increased Colorado River water deliveries to the Thomas E. L evy Recharge Facility (fig. 6), indicating that the increased water deliveries to the percolation ponds at the facility could have increased the head in the aquifer system. Water-level stabilization and recovery also could be caused by a reduction in groundwater pumping. These water-level recoveries may have reduced the subsidence rates in the La Quinta area during 2009-10 (fig. $16 E)$. Concomitant subsidence and declining water levels within these areas during 1993-2010, and reduced subsidence rates and recovering water levels in the $L$ a Q uinta area in 2009-10, indicated that aquifer-system compaction could be causing subsidence. 

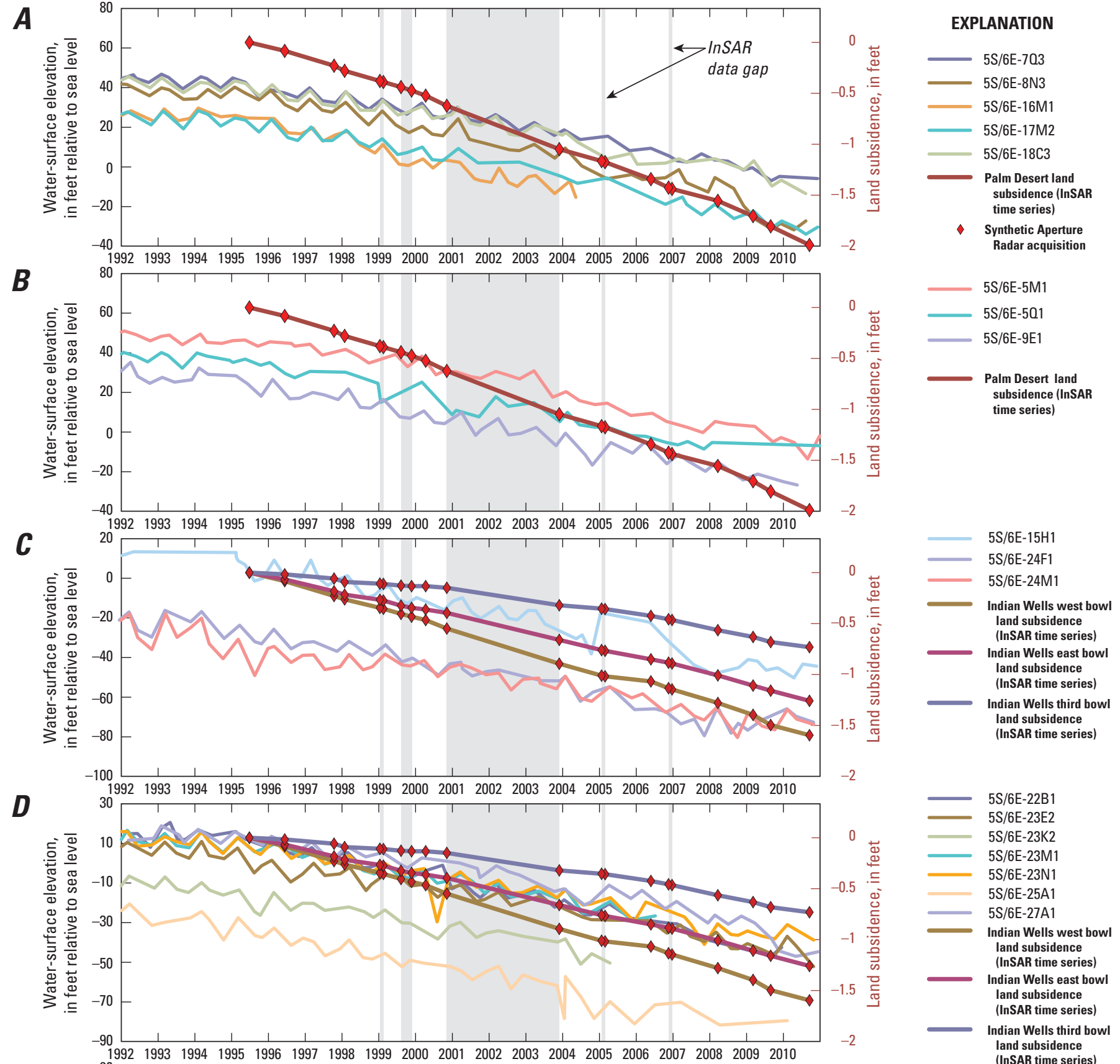

$\boldsymbol{E}$
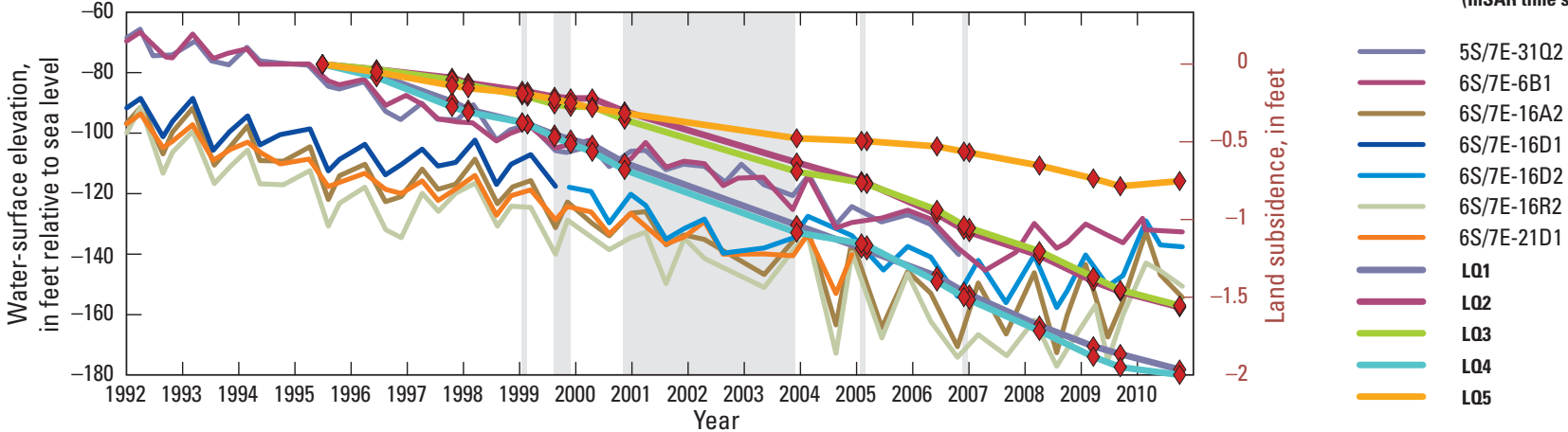

Figure 16. Water-surface elevations for selected wells and Interferometric Synthetic Aperture Radar (InSAR) time series showing land subsidence for June 27, 1995-September 19, 2010, A, within the Palm Desert area of subsidence and Palm Desert, respectively; $B$, outside the Palm Desert area of subsidence and Palm Desert, respectively; $C$, within the Indian Wells area of subsidence and in the west, east, and third bowls; $D$, outside the Indian Wells area of subsidence and the west, east, and third bowls; and $E$, in the La Quinta area of subsidence and five locations in La Quinta. See figures 7, 9, 11, and 13 for locations of land-subsidence time-series interpretations and wells. 


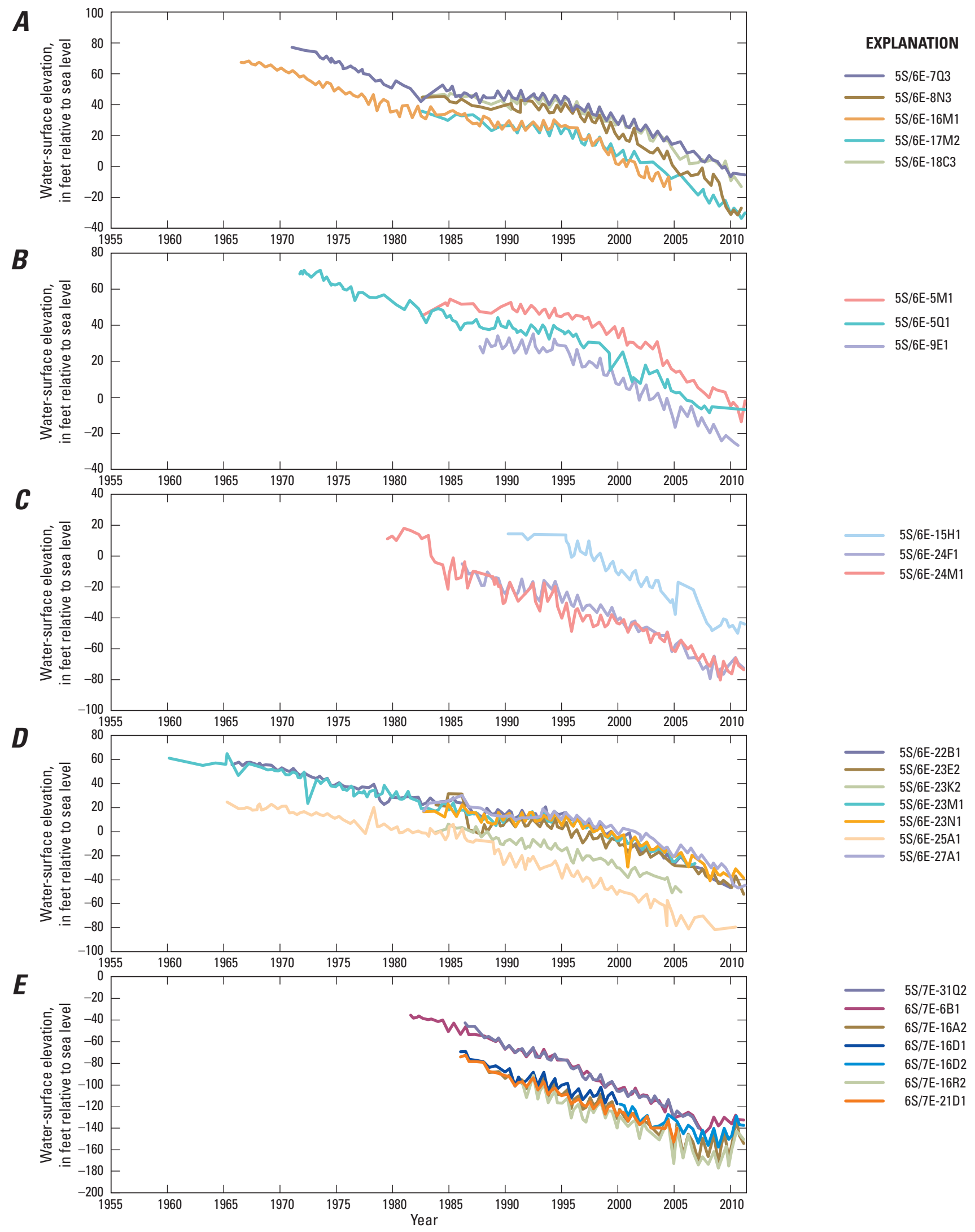

Figure 17. Water-surface elevations for selected wells in the Coachella Valley, California, $A$, for 1966-2010 within the Palm Desert area of subsidence; $B$, for 1971-2010 outside the Palm Desert area of subsidence; $C$, for 1979-2010 within the Indian Wells area of subsidence; $D$, for 1960-2010 outside the Indian Wells area of subsidence; and $E, 1981-2010$ within the La Quinta area of subsidence. See figures $7,9,11$, and 13 for location of wells. 


\section{Comparison of Global Positioning System and Interferometric Synthetic Aperture Radar Results}

\section{Comparison of Deformation Rates Derived from Global Positioning System-Survey and Interferometric Synthetic Aperture Radar Data}

Subsidence calculations derived from GPS and InSA R measurements were compared at 18 monuments (DEEP, MANI, MAGF, OSDO, DUNE, COCH, R70R, 5211, JA 54, CA HU, S753, C132, K 572, JOHN, C101, P572, SW C, and C427). GPS and InSAR measurements could not be compared at the other monuments, PAIN , K 70, and G 70 , because InSA R data did not include these locations. Rates of land subsidence that were derived from GPS survey data were cal culated by differencing the ellipsoid heights computed from the GPS surveys in 1996, 1998, 2000, 2005, and 2010 and dividing the resulting ellipsoid height differences by the time elapsed between the middle date of each of the five multi-day surveys: J une 20, 1996, October 5, 1998, A ugust 30, 2000, A ugust 17, 2005, and A ugust 25, 2010. Rates of land subsidence were determined from InSA R data at GPS monuments by computing the magnitude of land subsidence near each monument and, then, dividing that magnitude by the elapsed time of the interferogram.

Generally, GPS derived subsidence rates at the 18 monuments compared favorably with InSAR derived subsidence rates for similar periods. A Iso, the InSA R-derived subsidence rates at these monuments tended to fall within the error tolerances of the GPS surveys and showed similar deformation trends. GPS-derived deformation rates for 1996- 98 and 1998-2000, however, compared less favorably to InSA R derived rates than GPS derived rates for 2000-05 and 2005-10. This could be caused by higher errors in the individual 1996 and 2000 GPS survey data (table 1), the lower signal-to-noise ratios for the 2-year repeat surveys compared to the 5-year repeat surveys, differences in SA R data collection from ENVISAT as opposed to ERS satellites, differences in processing algorithms for the SA R data collected from the two satellites, or a combination of these factors.

\section{Comparison of Deformation Magnitudes Derived from Continuous-Global Positioning System and Interferometric Synthetic Aperture Radar Data}

Continuous GPS and InSAR data were compared at the CGPS sites COTD in Palm Desert and TM A P near Coachella (fig. 18). M agnitudes of subsidence derived from CGPS data and InSA R data were directly compared because continuously collected GPS data generally permits computation of a position for most days.

The coordinates for CGPS stations were obtained from and computed by SOPAC for most days between 0 ctober 15 , 1999, and J anuary 15, 2011, for COTD, and for most days between M arch 15, 2000, and December 9, 2010, for TM A P. Daily CGPS position time series were downloaded from the SOPAC ftp (file transfer protocol) website (ftp://garner.ucsd. $e d u$ / accessed J anuary 29, 2013). Day-to-day CGPS height solutions varied by as much as about $30 \mathrm{~mm}(0.10 \mathrm{ft})$, which is likely the result of variable atmospheric conditions, random walk (B rownian) noise, and other effects not directly related to land-surface-el evation change (Zerbini and others, 2001; Williams and others, 2004; L angbein, 2008). To minimize this high-frequency noise and to enable better correlation between changes in GPS heights and InSA R measurements, a 31-day moving average was applied to the CGPS data (fig. 18). The removal of the day-to-day variations in GPS heights did not remove seasonal or long-term deformation trends (fig. 18) and permitted more meaningful comparison with InSA R data. $D$ ata from COTD and TM A P were compared to the InSA R time series that spans the same or similar periods. InSA R measurements at COTD for A pril 12, 2000-September 19, 2010, indicated about $105 \mathrm{~mm}$ ( $0.34 \mathrm{ft}$ ) of subsidence, and CGPS observations indicated about $90 \mathrm{~mm}(0.30 \mathrm{ft})$ of subsidence (fig. 18A). InSA R measurements at TM A P for A pril 12, 2000-September 19, 2010, indicated about $15 \mathrm{~mm}$ $(0.05 \mathrm{ft}$ ) of subsidence (fig. 18B). Gaps in TM A P CGPS data prevented the comparison with InSA R subsidence magnitudes for the exact same period, but GPS data for A pril 30, 2000July 13, 2010 ( 86 days shorter than the InSAR time period), indicated about $25 \mathrm{~mm}(0.08 \mathrm{ft}$ ) of subsidence (fig. $18 B)$. Note the stabilization and subsequent uplift of TM A P beginning in mid-2009 after about 9 years of net annual subsidence (fig. 18B), which is consistent with the previously discussed slowing of subsidence or stabilization at geodetic monuments in the southern part of the geodetic network (figs. $4 \mathrm{~N}, 4 \mathrm{O}, 4 \mathrm{P}$, $4 Q, 4 R$ ).

The InSA R and GPS derived subsidence rates for most GPS monuments, and the InSAR and GPS derived subsidence magnitudes at COTD and TM AP generally compared favorably, which can provide confidence in results derived from both methods. 

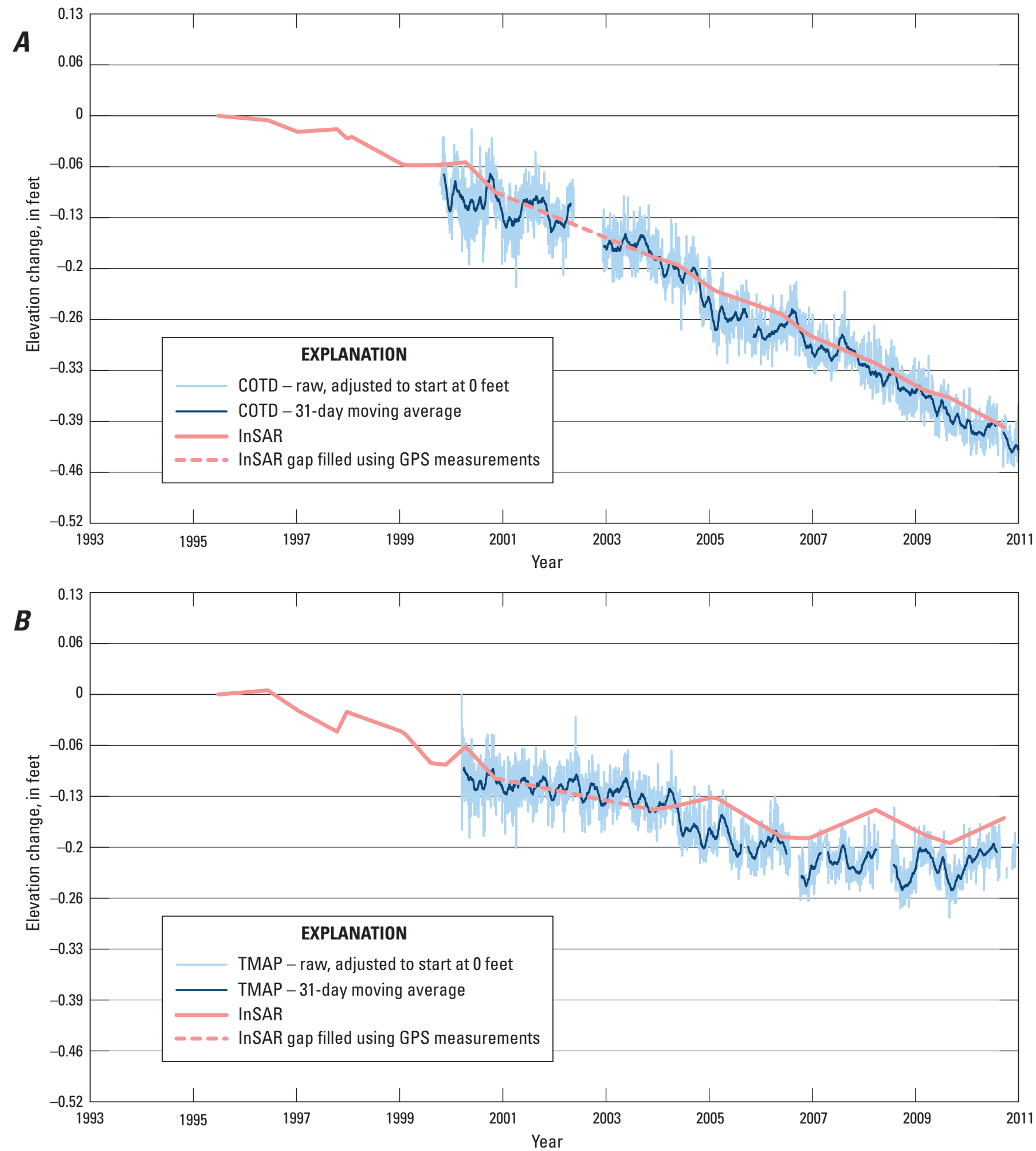

Figure 18. Vertical displacements measured by Continuous Global Positioning System (CGPS) and by Interferometric Synthetic Aperture Radar (InSAR) at CGPS stations, $A$, COTD, and $B$, TMAP. 


\section{Correlation of Land Subsidence, Groundwater Levels, Geologic Structures, and Fine-Grained Deposits}

In the area of investigation in the Coachella Valley, InSA R and GPS data collected during 1993-2010 indicated that most of the valley had subsided; areas of lesser subsidence were in the southcentral and southeastern parts of the valley, where agriculture and small communities are located, and areas of greater subsidence were in and near Palm Desert, Indian Wells, and La Quinta in the northern and central parts of the valley, where golf courses and other urban land use predominates (figs. 4, 8-14).

The areas of lesser subsidence in the southcentral and southeastern parts of the valley were coincident with locations where water levels generally were stable or recovered during 1993-2010, but had previous periods of declines (fig. $4 \mathrm{~N}$, $4 O, 4 P, 4 Q, 4 R, 5 B)$. For these areas, substantial future permanent subsidence caused by aquifer-system compaction would not be expected as long as water levels remained above their historical low levels, thereby preventing aquifersystem effective stresses from exceeding the preconsolidation stresses. $\mathrm{N}$ early all of the vertical changes in land surface (caused by aquifer-system compaction) that could occur while water levels remain above historical low levels would be recoverable.

The areas of greatest subsidence were near the western margin of the valley (fig. 8). Water levels in most wells in and near the western margin declined to their lowest recorded levels each year during 1993-2010 and during much of the 20th century (figs. 4C, 4D, 4E, 5A, 16, 17). The coincident areas of subsidence and declining water levels, and the localized character of the subsidence signals that are typical of subsidence caused by localized pumping, indicated that subsidence was caused by aquifer-system compaction. The stresses imposed by the declining water levels and the substantial subsidence in the areas of greatest subsidence indicated that the effective stresses have exceeded the preconsolidation stresses in parts of the aquifer system; if so, the subsidence could be largely permanent in these areas.

A lthough the areas of greatest subsidence were limited to the western margin of the valley, water levels have reached historic lows in neighboring areas, where spatially-detailed InSA R data indicated much less subsidence (figs. $4 A, 4 B, 4 K$, $5 A, 8,16,17)$. Similar hydrographs from areas with differing subsidence indicated that fine-grained compressible sediments were preferentially deposited in the western margin of the valley. The InSA R data indicated that the areal extent of subsidence terminates abruptly to the northeast of Palm Desert and Indian Wells, forming northwest to southeast trending lineaments in the interferograms that are coincident with an inferred fault (J ennings, 1977; figs. 8, 9, 11). In La Quinta, the areal extent of subsidence was not terminated as abruptly as in Palm Desert or Indian Wells, but the magnitude of subsidence decreased rapidly over a fairly short distance, which coincides with the same inferred fault (J ennings, 1977; figs. 8, 13).
A brupt areal changes in subsidence can be the result of faults separating compressible from less-compressible deposits or acting as barriers to groundwater flow, creating groundwaterlevel differences across the faults (Galloway and others, 1999). B ecause groundwater levels were similar on both sides of the inferred fault (figs. 16A-D, 17A-D), differences in the compressibilities of the sediments across the inferred fault are probable. A nalyses of lithological and geophysical logs of wells can provide some clues about the observed subsidence patterns that terminate or change character near the inferred fault (J ennings, 1977).

The available lithological and geophysical data indicated that the aquifer-system on the southwest side of the inferred fault (fig. 19A, B) contains substantially more fine-grained deposits as compared to the northeast side of the inferred fault, where fine-grained deposits are nearly absent (fig. 19C). Furthermore, the lithological data on the southwest side of the inferred fault and within the Palm Desert and Indian Wells subsidence areas indicated clay beds as thick as about $61 \mathrm{~m}$ (200 ft; fig. 19B). Similarly, the lithological data from boreholes near L Q1 (figs. 7, 8, 13, 14), an area of rapid subsidence in $\mathrm{L}$ a Quinta, also indicated thick clay sequences (fig. 19D); the aggregate thickness of clay beds decreases near the margins of the subsidence in this area (fig. 19E). The presence of thick clay beds is consistent with the steady subsidence rates cal culated for these areas; the subsidence rates were fairly steady even during seasonal periods of water-level recovery. Subsidence during waterlevel recoveries indicates that residual compaction could be a substantial component of total compaction in these areas. Furthermore, current groundwater levels, many of which were the lowest recorded levels, lie within or above sequences of thick clay beds. This positional relationship indicates that the historically lowered water levels increased effective stresses that likely exceeded preconsolidation stresses in some of these sequences, which would have caused inelastic compaction.

In the southern part of the $L$ a Q uinta subsidence area near LQ 4 and LQ 5 (figs. 7, 8, 13, 14), lithologic correlation among boreholes generally was not possible, indicating more lithologic heterogeneity than in the other subsiding areas. The available lithologic data did not indicate the presence of thin clay beds in this area (borehole lithologic descriptions often are generalized such that thin beds are not described), al though the rapid subsidence cessation and subsequent uplift at L Q5 as water levels recovered starting about mid-2009 (fig. 16E) indicated they could be present. The rapid change in subsidence rates as water levels recovered indicates that either residual compaction was not a substantial component of total compaction in this area or that the elastic expansion of thinner aquitards and coarser-grained material masked residual compaction in thick aquitards. If residual compaction was not substantial in this area, then substantial subsidence is not expected to recur if water levels are maintained above 2008 levels. However, if there is residual compaction, or groundwater levels decline to or below 2008 levels, then subsidence can be expected to resume. 


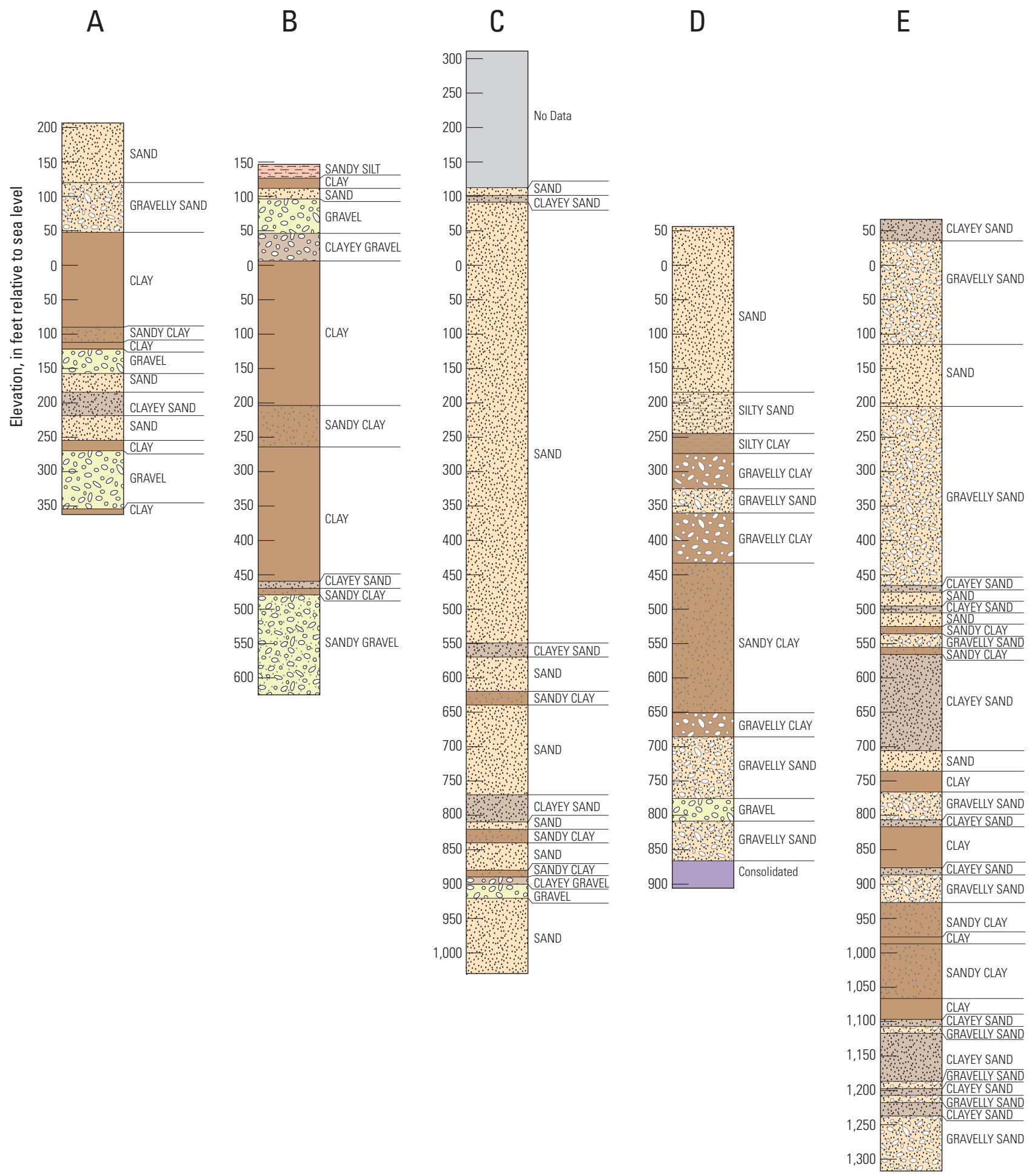

Figure 19. Stratigraphic columns showing lithology, $A$, within the Palm Desert subsidence area and southwest of an inferred fault; $B$, within the Indian Wells subsidence area and southwest of an inferred fault; $C$, outside of the Palm Desert subsidence area and northeast of an inferred fault; $D$, within the La Quinta subsidence area; and $E$, near the margin of the La Quinta subsidence area. 


\section{Future Monitoring}

Continued monitoring in the southern Coachella Valley is warranted because groundwater levels continue to decline to record-low levels in some areas of the valley, and therefore, the magnitudes and rates of land subsidence documented by this study can be expected to continue. The CV W D is currently involved in several agreements and projects, however, that could reduce reliance on the groundwater resource, and continued monitoring could track the effect these agreements and projects have on the aquifer system. For instance, Colorado River water allocations are changing; complex water transfers according to the Quantification Settlement A greement are being implemented; and mitigation measures including tiered rate structures, aquifer-recharge projects, and conversion from groundwater to surface water resources for irrigation for (primarily) golf courses by the M id-Valley Pipeline Project are being instituted, which have the potential to change the reliance on the groundwater resource.

M ost of the elevation changes of the G PS network monuments between 1996 and 1998, and between 1998 and 2000 , were less than or similar to their measurement uncertainties, indicating that more time is needed before significant elevation changes can be measured. The changes of GPS network monument el evations between 2000 and 2005, and between 2005 and 2010, were mostly similar to their measurement uncertainties, but indicated significant subsidence at some monuments. Consequently, GPS surveys are recommended at intervals of 5 years. Processing of spatially detailed InSA R-derived maps of ground displacements, however, could continue annually, or more frequently (depending on data availability), because InSA R can detect el evation changes as small as $5 \mathrm{~mm}(0.02 \mathrm{ft}$; H offmann and others, 2001). B ecause InSA R-detected areas of subsidence overlap the GPS network, GPS network monitoring could provide validation of InSA R measurements, as in this study. A s InSA R technology matures, it could provide improved subsidence measurements in agriculturally active areas, such as those in the southern Coachella Valley.

D etailed lithologic and geophysical logging of boreholes could greatly improve knowledge of lithologic sequences in the subsurface. Detailed information on the individual and aggregate thickness of highly compressible fine-grained sediments could improve potential subsidence predictions derived from analytical methods or numerical hydromechanical models. This lithologic data can be obtained as new wells are drilled or existing wells are redrilled.

The frequency of water-level measurements in the Coachella Valley is less than those of InSA R measurements and, therefore, are too low to permit meaningful interpretations of the aquifer-system mechanical response to water-level changes. Furthermore, the wells generally have long or multiple screens, such that the water-level measurements represent a composite of water levels throughout a large thickness of the aquifer system. Increasing the measurement frequency of groundwater levels in piezometers (wells constructed with short screens and small diameters for monitoring purposes) - both in areas of known subsidence and in areas of relative stability - would substantially improve analysis of the relationship between changes in water levels and in land-surface elevations. In concert with these more frequent water-level measurements, frequent high-resolution measurements of aquifer-system compaction, such as from borehole extensometers, would improve the analysis of aquifer-system response. A low-cost surrogate for this type of monitoring site was assembled in 2009 by instrumenting a former production well near the CGPS station COTD to measure hourly groundwater levels. Information from such monitoring sites would be useful for estimating aquifer-system properties that govern groundwater flow and land subsidence. This information could be useful in constraining a numerical model of groundwater flow and aquifer-system compaction that could hel p quantify relations between groundwater levels, subsidence, and other geologic processes, and could predict land subsidence for various water management scenarios.

\section{Summary}

Groundwater has been a major source of agricultural, municipal, and domestic water supply in the Coachella Valley since the early 1920s. Groundwater levels declined throughout the Coachella Valley from the 1920s until 1949. In 1949, the importation of surface water from the Colorado River to the southern Coachella Valley began, resulting in decreased pumping and recovery of water levels in some areas. Since the 1970s, the demand for water in the southern Coachella Valley has exceeded the deliveries of the imported surface water, and water levels have again declined. The declining water levels have the potential to induce or renew land subsidence in the Coachella Valley. Results of previous studies by the U.S. Geological Survey (USGS) indicated that land subsidence could have been as much as 150 millimeters ( $\mathrm{mm}$ ) or $0.5 \mathrm{feet}(\mathrm{ft})$ in the southern parts of the valley between about 1930 and 1996 (Ikehara and others, 1997).

During 1993-2010, the location and magnitude of landsurface el evation changes were measured by the U SGS by using G lobal Positioning System (GPS) and Interferometric Synthetic A perture Radar (InSA R) techniques. The GPS measurements and the images processed for the InSA R measurements described in this report span the area from Palm Desert on the north to the Salton Sea on the south. GPS measurements have traditionally been more useful than InSA R measurements for determining vertical land-surface changes in agricultural areas. However, application of the persistent scatterer (PS) InSA R technique has permitted more detailed examination of land-surface el evation changes in agricultural areas. GPS measurements taken at 11 geodetic monuments in 1996 and in 2010 in the southern Coachella Valley indicated that the el evation of the land surface changed -136 to $-23 \mathrm{~mm}$ 
$\pm 54 \mathrm{~mm}(-0.45$ to $-0.08 \mathrm{ft} \pm 0.18 \mathrm{ft})$ during the 14 -year period. Changes at 6 of the 11 monuments exceeded the maximum expected uncertainty of $\pm 54 \mathrm{~mm}( \pm 0.18 \mathrm{ft}$ ) at the 95 -percent confidence level, indicating subsidence at these monuments between June 1996 and A ugust 2010. The GPS measurements taken at 17 monuments in 2005 and in 2010 indicated that the land-surface el evation changed -256 to $+16 \mathrm{~mm} \pm 28 \mathrm{~mm}$ $(-0.84$ to $+0.05 \mathrm{ft} \pm 0.09 \mathrm{ft})$ during that 5 -year period. Changes at 5 of the 17 monuments exceeded the maximum expected uncertainty of $\pm 28 \mathrm{~mm}( \pm 0.09 \mathrm{ft})$ at the 95 -percent confidence level, indicating subsidence at these monuments between August 2005 and August 2010. At each of these five monuments, subsidence rates were about the same between 2005 and 2010 as between 2000 and 2005.

InSA R measurements taken between J une 27, 1995, and September 19, 2010, indicated land subsidence from about 220 to $600 \mathrm{~mm}(0.72-1.97 \mathrm{ft})$ in three areas of the Coachella Valley: near Palm Desert, Indian Wells, and La Quinta. The average subsidence rates in Palm Desert increased from about $39 \mathrm{~mm} / \mathrm{yr}(0.13 \mathrm{ft} / \mathrm{yr})$ during $1995-2000$ to about $45 \mathrm{~mm} / \mathrm{yr}$ (0.15 ft/yr) during 2003-10. The average subsidence rates for two subsidence maxima in Indian Wells were about 34 and $26 \mathrm{~mm} / \mathrm{yr}(0.11$ and $0.09 \mathrm{ft} / \mathrm{yr})$ for both periods, indicating fairly steady rates; average subsidence rates for the third maxima in Indian Wells increased from about 14 to $19 \mathrm{~mm} / \mathrm{yr}$ ( 0.05 to $0.06 \mathrm{ft} / \mathrm{yr}$ ) between the two periods. Average subsidence rates for five selected locations in the L a Quinta subsidence area ranged from about 17 to $37 \mathrm{~mm} / \mathrm{yr}$ ( 0.06 to $0.12 \mathrm{ft} / \mathrm{yr}$ ) during 1995-2000; three of the locations had similar rates during 2003-mid-2009, while the other two locations had increased subsidence rates. However, decreased subsidence rates were calculated throughout the L a Quinta subsidence area during mid-2009-2010, and uplift was observed during 2010 in an area near the southern extent of this subsidence area.

Water-level measurements taken at wells near the subsiding monuments and in the three areas of subsidence shown by InSA R generally indicated that water levels declined from the early 1990s to 2010; in 2010, some water levels were at the lowest levels in their recorded histories. A n exception to annually declining water levels in and near subsiding areas was observed beginning in mid-2009 in the La Quinta subsidence area, where recovering water levels coincided with increased recharge operations at the Thomas E. L evy Recharge Facility. The concomitant areas of subsidence and declining water levels, and of reduced subsidence rates and recovering water levels, indicate that aquifer-system compaction likely is causing subsidence. If the stresses imposed by the historically lowest water levels in some areas caused effective stresses to exceed the preconsolidation stress, the aquifer-system compaction and associated land subsidence could be permanent. Continued monitoring in the southern Coachella Valley is warranted because groundwater levels continue to decline to record-low levels in some areas of the valley, and the considerable magnitudes and steady or increasing subsidence rates documented by this study are, therefore, expected to continue. A dditionally, as the water-supply portfolio of the Coachella Valley Water District changes through various projects that could reduce reliance on the groundwater resource, continued monitoring can help track effects on the aquifer system and help inform future mitigation measures.

\section{References}

A twater, Tanya, 1970, Implications of plate tectonics for the Cenozoic tectonic evolution of western N orth A merica: Geological Society of A merica B ulletin, v. 81, p. 35133536.

B awden, G.W., Sneed, M., Stork, S.V., and Galloway, D.L., 2003, M easuring human-induced land subsidence from space: U.S. Geological Survey Fact Sheet 069-03, 4 p.

Beck, N., Duval, R., and Taylor, P., 1989, GPS processing methods: Comparison with precise trilateration: J ournal of Surveying Engineering, v. 115, no. 2, p. 181-197.

B eutler, G., B auersima, I., Gurtner, W., and R othacher, M., 1987, Correlations between simultaneous GPS double difference carrier phase observations in the multistation mode: Implementation considerations and first experiences: M anuscripta Geodaetica, v. 12, p. 40-44.

California D epartment of Water Resources, 1964, Coachella Valley investigation: California Department of Water Resources, Bulletin 108, 145 p.

California D epartment of Water Resources, 1979, Coachella Valley area well standards investigation: L os A ngeles, California Department of Water R esources, Southern District, $40 \mathrm{p}$.

Coachella Valley Water District, 2012, Coachella Valley Water M anagement Plan 2010 U pdate, Final Report, 286 p., accessed J anuary 31, 2014, at http://www.cvwd.org/news/ publicinfo/2013_10_01_CoachellaValleyWaterManagement PlanFinalReport.pdf.

Craymer, M.R., and Beck, N., 1992, Session versus baseline GPS processing, in the Proceedings of the 5th International Technical $\mathrm{M}$ eeting of the Institute of $\mathrm{N}$ avigation: A lbuquerque, N ew M exico, Institute of Navigation GPS-92, September 16-18, 1992.

Crowell, B.W., Bock, Y ehuda, Sandwell, D.T., and Fialko, Yuri, 2013, Geodetic investigation into the deformation of the Salton Trough: J ournal of Geophysical Research: Solid Earth, v. 118, p. 5030-5039. 
Fuis, Gary S., and M ooney, W.D., 1990, Lithospheric structure and tectonics from seismic-refraction and other data, in The San A ndreas Fault System, California: U.S. Geological Survey Professional Paper 1515, p. 207-236.

Galloway, D.L., Jones, D.R ., and Ingebritsen, S.E., 1999, L and subsidence in the U nited States: U.S. G eological Survey Circular 1182, $175 \mathrm{p}$.

Han, Shaowei, and Rizos, Chris, 1995, Selection and scaling of simultaneous baselines for GPS network adjustment, or correct procedures for processing trivial baselines: Geomatics Research A ustralasia, no. 63, p. 51-66.

Hanson, R.T., 1989, A quifer-System Compaction, Tucson $B$ asin and Avra Valley, A rizona: U.S. Geological Survey Water-Resources Investigations Report 88-4172, 69 p.

H offmann, J., Zebker H.A., Galloway, D.L., and A melung, F., 2001, Seasonal subsidence and rebound in L as Vegas Valley, N evada, observed by synthetic aperture radar interferometry: Water Resources Research, v. 37, no. 6, p. 1551-1566.

Hollmann, R., O swald, W., and Welsch, W., 1990, Processing of GPS phase observations in every day life: How much can various network solutions differ and how can they be compared?: M anuscripta Geodaetica, v. 15, p. 124-136.

Holzer, T.L., 1984, Ground failure induced by ground-water withdrawal from unconsolidated sediment: R eviews in Engineering Geology, v. 6, p. 67-105.

Holzer, T.L., 1998, The history of the aquifer-drainage model, in B orchers, J., ed., L and Subsidence-C ase Studies and Current R esearch, Proceedings of the Dr. J oseph F. Poland Symposium: A ssociation of Engineering Geologists Special Publication 8, p. 7- 12.

Ikehara, M .E., Predmore, S.K ., and Swope, D.J ., 1997, Geodetic network to evaluate historical elevation changes and to monitor land subsidence in L ower Coachella Valley, California, 1996: U.S. Geological Survey Water-R esources Investigations Report 97-4237, scale 1:63,000, 1 sheet [folded in envelope].

I reland R.L., Poland, J.F., and Riley, F.S., 1984, L and subsidence in the San J oaquin Valley, California, as of 1980: U.S. Geological Survey Professional Paper 437-I, 93 p., accessed A ugust 18, 2008, at http://pubs.er.usgs.gov/ usgspubs/pp/pp437I.

J ennings, C.W., 1977, Geologic M ap of California: California Division of Mines and Geology, Geologic Data M ap No. 2, scale 1:750,000.

L angbein, J ohn, 2008, N oise in GPS displacement measurements from Southern California and Southern Nevada: J ournal of Geophysical Research, v. 113, B 05405, $12 \mathrm{p}$.
Leake, S.A ., and Prudic, D.E., 1991, Documentation of a computer program to simulate aquifer-system compaction using the modular finite-difference ground-water flow model: U.S. Geological Survey Techniques of WaterResources Investigations, book 6, chap A 2, 68 p.

M cK ibben, M .A ., 1993, The Salton Trough rift, in Reynolds, R.E., and Reynolds, Jennifer, eds., A shes, faults, and basins: San Bernardino County M useum A ssociation Special Publication, v. 93-1, p. 76-80.

M einzer, O.E., 1928, Compressibility and elasticity of artesian aquifers: Economic Geology, v. 23, no. 3, p. 263-291.

M eltzner, A .J., Rockwell, T.K ., and Owen, L.A., 2006, Recent and long-term behavior of the $B$ rawley Fault Zone, Imperial Valley, California: an escalation in slip rate?: Bulletin of the Seismological Society of A merica, v. 96, no. 6, p. 23042328.

$\varnothing$ vstedal, Ola, 2000, Single processed independent and trivial vectors in network analysis: J ournal of Surveying Engineering, v. 126, no. 1, p. 18-25.

Phillips, S.P., Carlson, C.S., M etzger, L.F., Howle, J.F., Galloway, D.L., Sneed, M ichelle, Ikehara, M .E., Hudnut, K.W., and King, N.E., 2003, A nalysis of tests of subsurface injection, storage, and recovery of freshwater in L ancaster, A ntelope Valley, California: U.S. Geological Survey WaterResources Investigations Report 03-4061, 122 p.

Poland, J.F., ed., 1984, Guidebook to studies of land subsidence due to ground-water withdrawal, v. 40 of UNESCO Studies and Reports in Hydrology: Paris, France, United Nations Educational, Scientific and Cultural Organization, 305 p., 5 appendixes.

Riley, F.S., 1998, M echanics of aquifer systems- The scientific legacy of Joseph F. Poland, in Borchers, J., ed., $L$ and subsidence- Case Studies and Current Research: Proceedings of the Dr. Joseph F. Poland Symposium on $L$ and subsidence, A ssociation of Engineering G eologists Special Publication 8, p. 13-227.

Shen, Z.-K ., A gnew, D.C., K ing, R.W., Dong, D., Herring, T.A., Wang, M., Johnson, H., A nderson, G., Nikolaidis, R., van D omselaar, M ., Hudnut, K.W., and J ackson, D.D., 2003, The SCEC crustal motion map, Version 3.0, http://epicenter.usc.edu/cmm3, accessed A pril 19, 2007.

Sneed, M ichelle, and Galloway, D.L., 2000, A quifer-system compaction and land subsidence: M easurements, analyses, and simulations - the Holly site, Edwards A ir Force B ase, A ntelope Valley, California: U.S. Geological Survey WaterResources Investigations Report 00-4015, 65 p. 
Sneed, Michelle, Ikehara, M .E., Galloway, D.L., and A melung, Falk, 2001, Detection and measurement of land subsidence using global positioning system and interferometric synthetic aperture radar, Coachella Valley, California, 1996-98: U.S. G eological Survey WaterResources Investigations Report 01-4193, 26 p.

Sneed, Michelle, Stork, S.V., and Ikehara, M .E. 2002, Detection and measurement of land subsidence using global positioning system and interferometric synthetic aperture radar, Coachella Valley, California, 1998-2000: U.S. Geological Survey Water-Resources Investigations Report 02-4239, 29 p.

Sneed, Michelle, and B randt, J.T., 2007, D etection and measurement of land subsidence using global positioning system and interferometric synthetic aperture radar, Coachella Valley, California, 1996-2005: U.S. Geological Survey Scientific Investigations Report 2007-5251, v. 2.0, $31 \mathrm{p}$.

Strozzi, Tazio, Wegmüller, U rs, Werner, Charles, Teatini, Pietro, and Tosi, Luigi, 2005, SA R interferometric point target analysis and application to the monitoring of land subsidence in the Venice lagoon: Proceedings of the Seventh International Symposium on L and Subsidence, p. 417.

Sylvester, A .G., and Smith, R.R ., 1976, Tectonic transpression and basement-controlled deformation in San A ndreas Fault Zone, Salton Trough, California; A merican A ssociation of Petroleum Geologists Bulletin, v. 60, no. 12, p. 2081-2102.

Terzaghi, K arl, 1925, Principles of soil mechanics, IV Settlement and consolidation of clay: Engineering NewsRecord, v. 95, no. 3, p. 874-878.
Tyley, S.J., 1971, A nalog model study of the ground-water basin of the upper Coachella Valley, California: U.S. Geological Survey Open-File Report, 89 p.

Werner, C., Wegmüller, U ., Strozzi, T., and W iesmann, A ., 2003, Interferometric point target analysis for deformation mapping: in IGARSS 2003, Institute of Electrical and Electronics Engineering, v. V II, p. 4362-4364.

Williams, S.D.P., B ock, Yehuda, Fang, Peng, J amason, Paul, Nikolaidis, R.M ., Prawirodirdjo, Linette, M iller, M eghan, and J ohnson, D.J ., 2004, Error analysis of continuous GPS position time series: J ournal of Geophysical Research, v. 109, B 03412, 19 p.

Zebker, H.A ., Rosen, P.A ., and Hensley, S., 1997, A tmospheric effects in interferometric synthetic aperture radar surface deformation and topographic maps: J ournal of Geophysical Research, v. 102, p. 7547-7563.

Zerbini, Susanna, Richter, B ernd, N egusisi, M onia, Romagnoli, Claudia, Simon, Dietrich, Domenichini, Francesco, and Schwahn, Wolfgang, 2001, Height and gravity variations by continuous GPS, gravity, and environmental parameter observations in the southern Po Plain, near B ologna, I taly: Earth and Planetary Science Letters, v. 192, no. 3, p. 267-279.

Zilkoski, D.B., D'O nofrio, J.D., and Frakes, S.J ., 1997, Guidelines for establishing GPS-derived ellipsoid heights, (Standards: $2 \mathrm{~cm}$ and $5 \mathrm{~cm}$ ) version 4.3: Silver Spring, M d., N ational Geodetic Survey, 10 p., 3 appendices. 


\section{Appendix A. Persistent Scatterer Interferometric Synthetic Aperture Radar (PS InSAR) Interferograms, Coachella Valley, California}



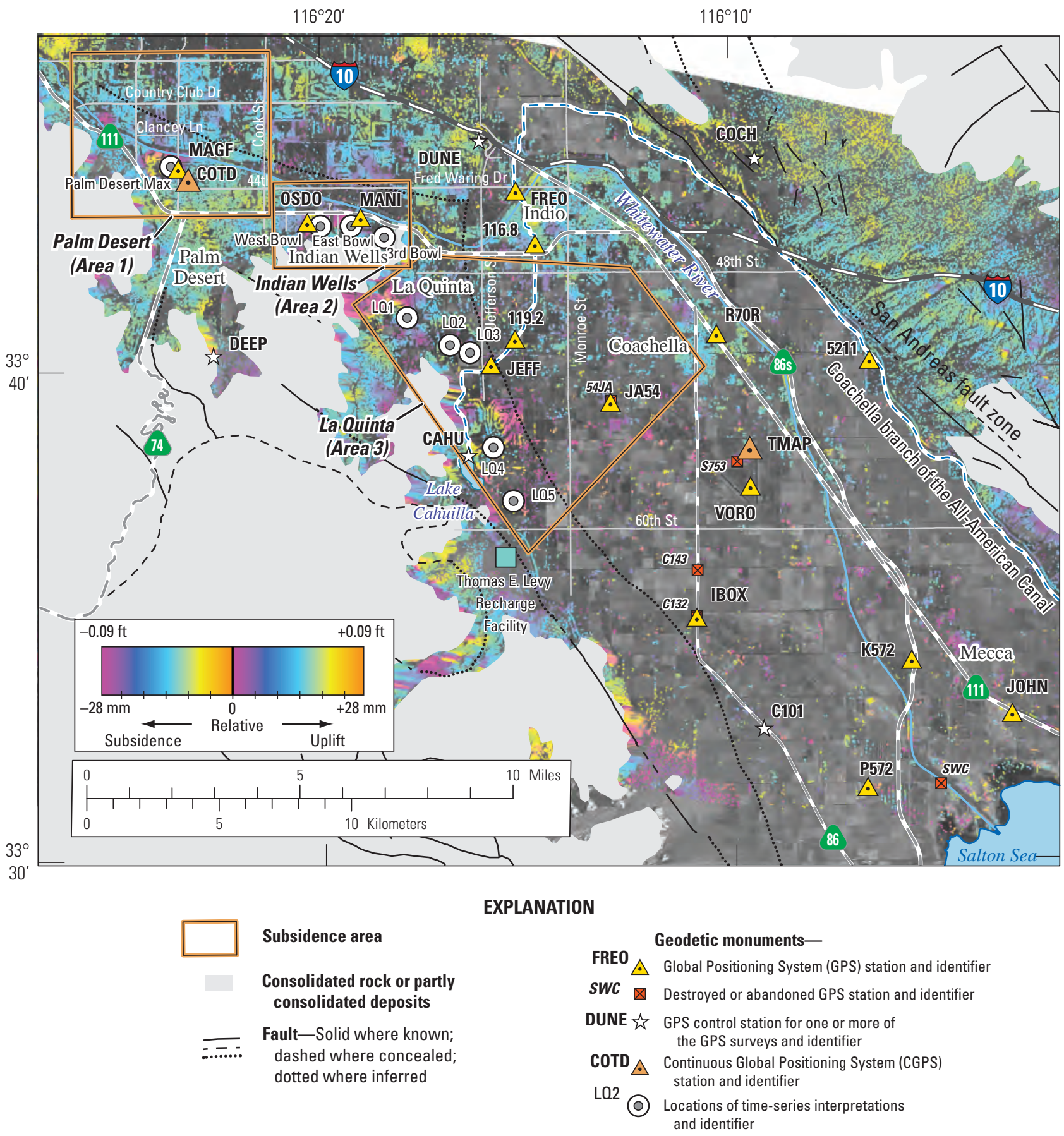

Figure A1. PS InSAR interferogram for Coachella Valley, California: June 27, 1995-June 12, 1996. 


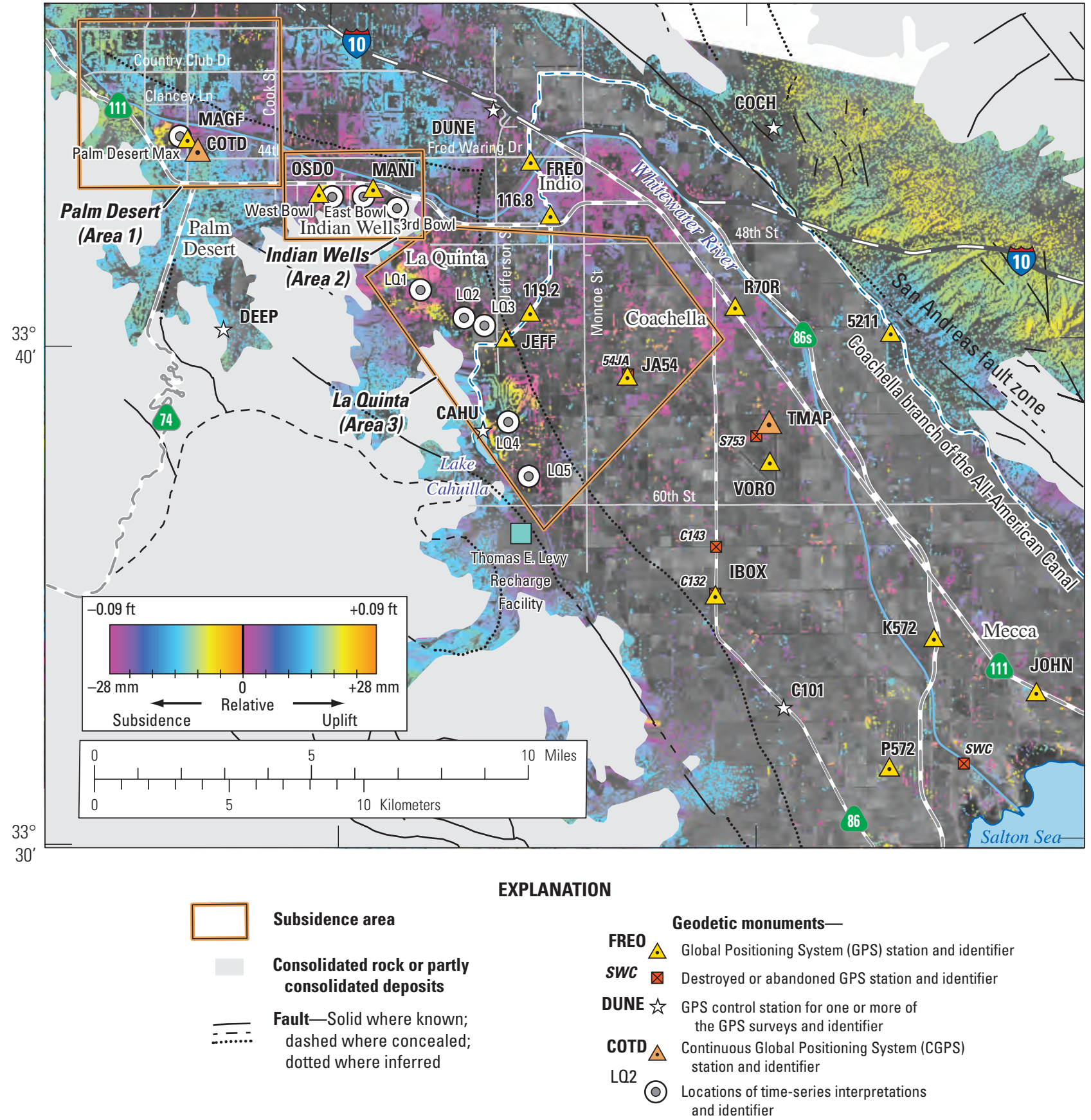

Figure A2. PS InSAR interferogram for Coachella Valley, California: April 2, 1996-January 8, 1997. 


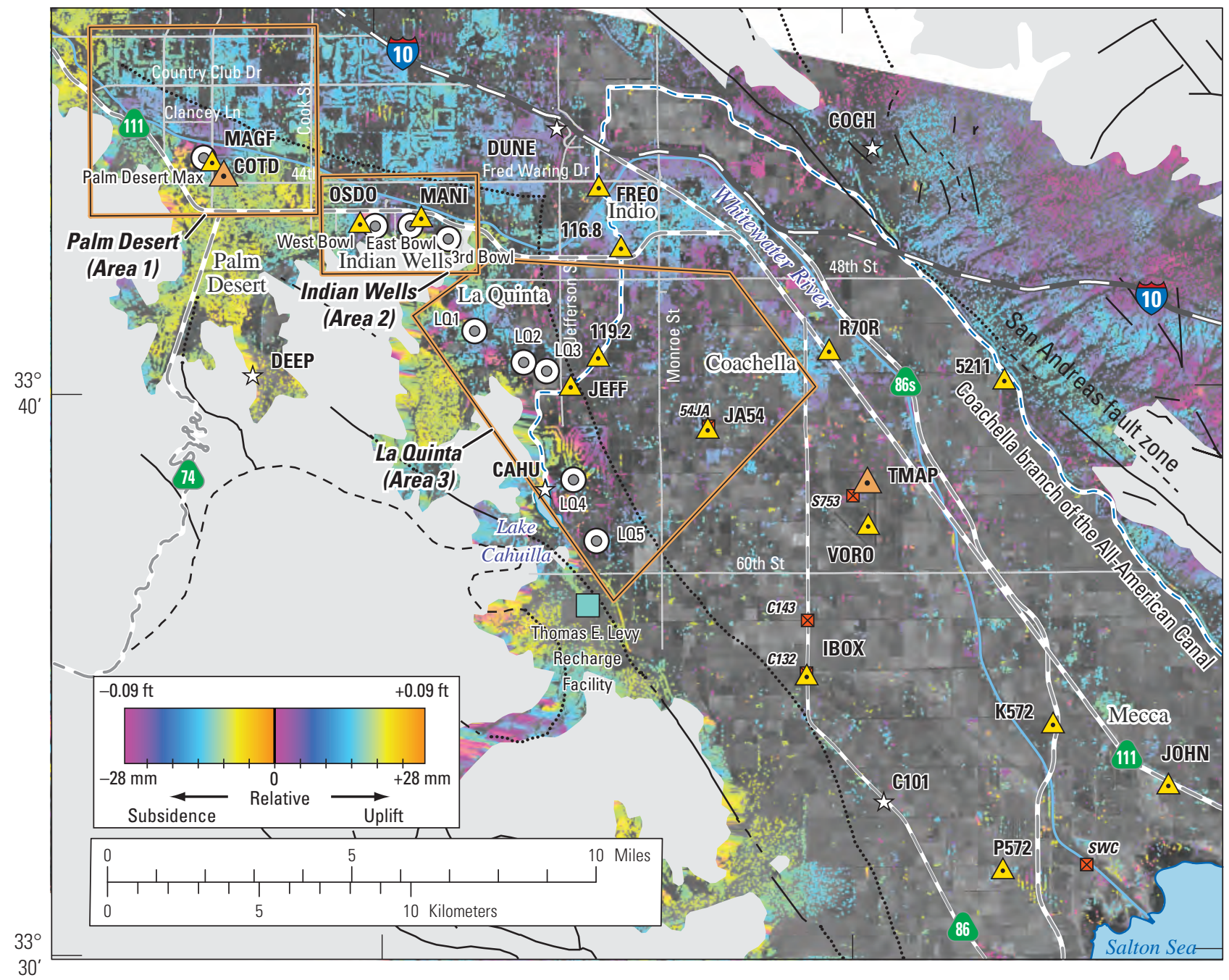

\section{EXPLANATION}

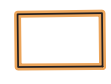

Subsidence area

Consolidated rock or partly consolidated deposits

- Fault-Solid where known; dotted where inferred

FREO Geodetic monuments-
SWC $\begin{gathered}\text { Global Positioning System (GPS) station and identifier } \\ \text { Destroyed or abandoned GPS station and identifier }\end{gathered}$
DUNE trs control station for one or more of
GOTD
the GPS surveys and identifier
LO2 Continuous Global Positioning System (CGPS)
station and identifier
Locations of time-series interpretations
and identifier

Figure A3. PS InSAR interferogram for Coachella Valley, California: January 8-0ctober 15, 1997. 


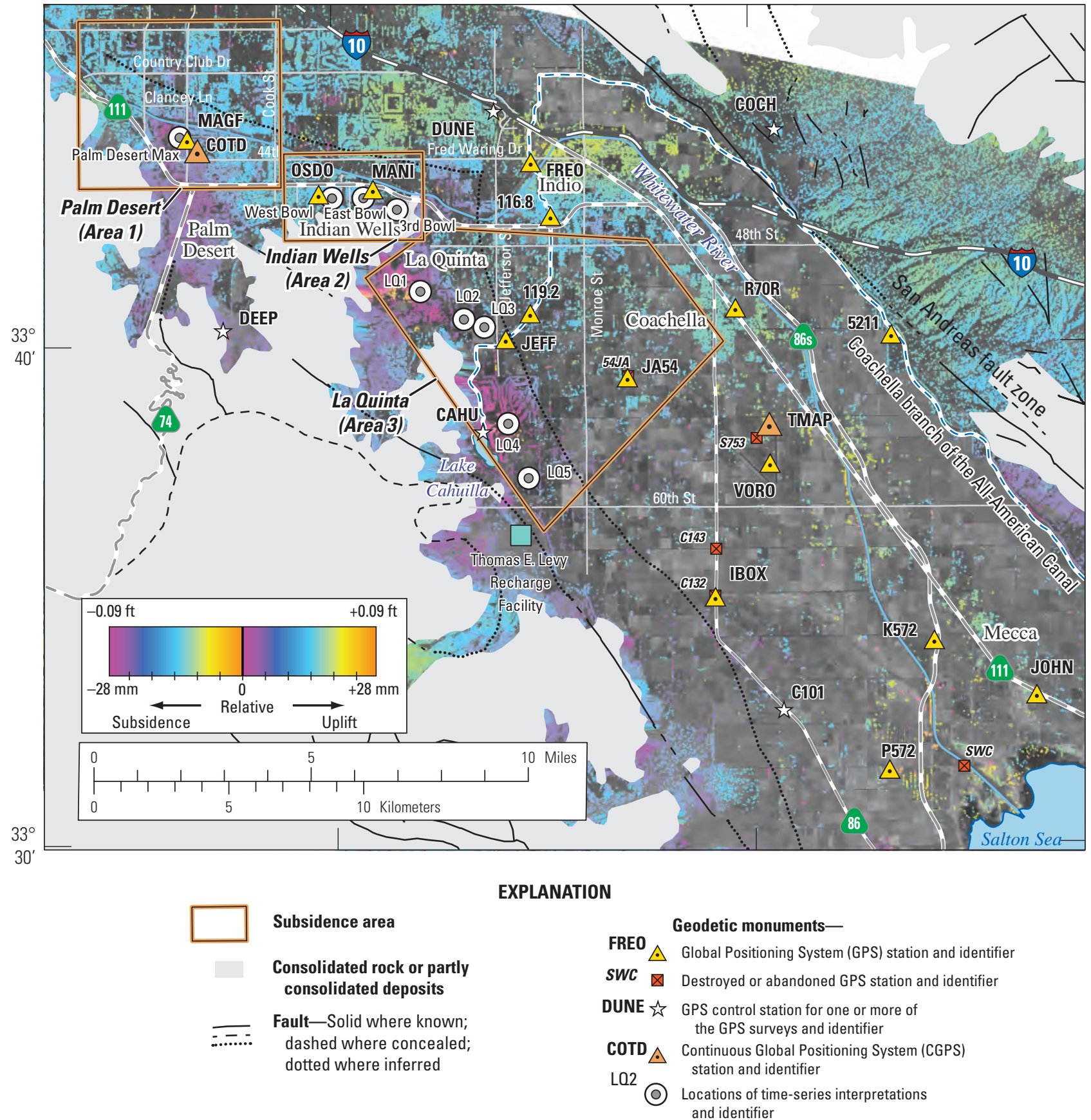

Figure A4. PS InSAR interferogram for Coachella Valley, California: October 15-December 24, 1997. 


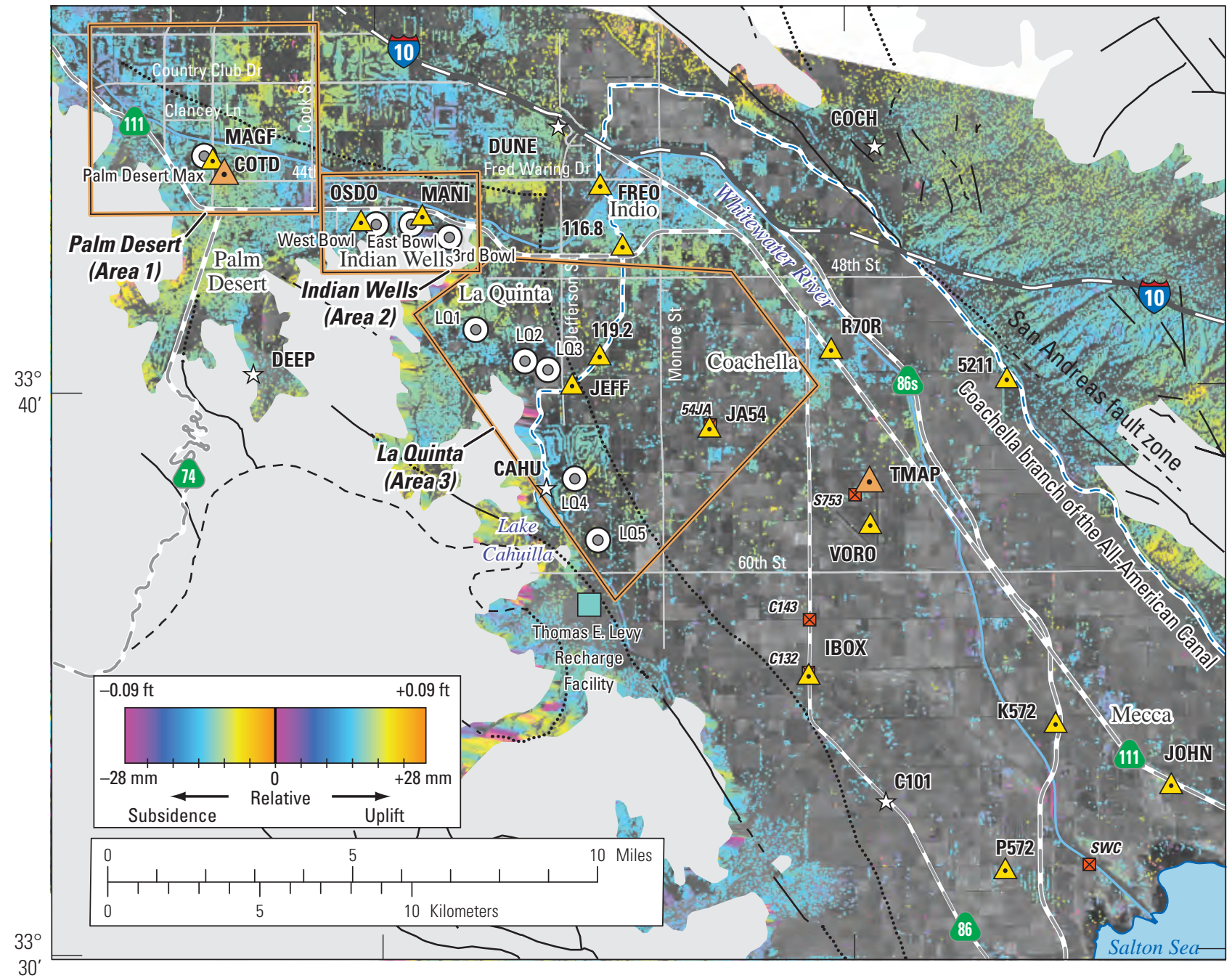

\section{EXPLANATION}

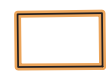

Subsidence area

Consolidated rock or partly consolidated deposits

- Fault-Solid where known; dotted where inferred

FREO Geodetic monuments-
SWC $\begin{gathered}\text { Global Positioning System (GPS) station and identifier } \\ \text { Destroyed or abandoned GPS station and identifier }\end{gathered}$
DUNE trs control station for one or more of
GOTD
the GPS surveys and identifier
LO2 Continuous Global Positioning System (CGPS)
station and identifier
Locations of time-series interpretations
and identifier

Figure A5. PS InSAR interferogram for Coachella Valley, California: December 24, 1997-January 28, 1998. 


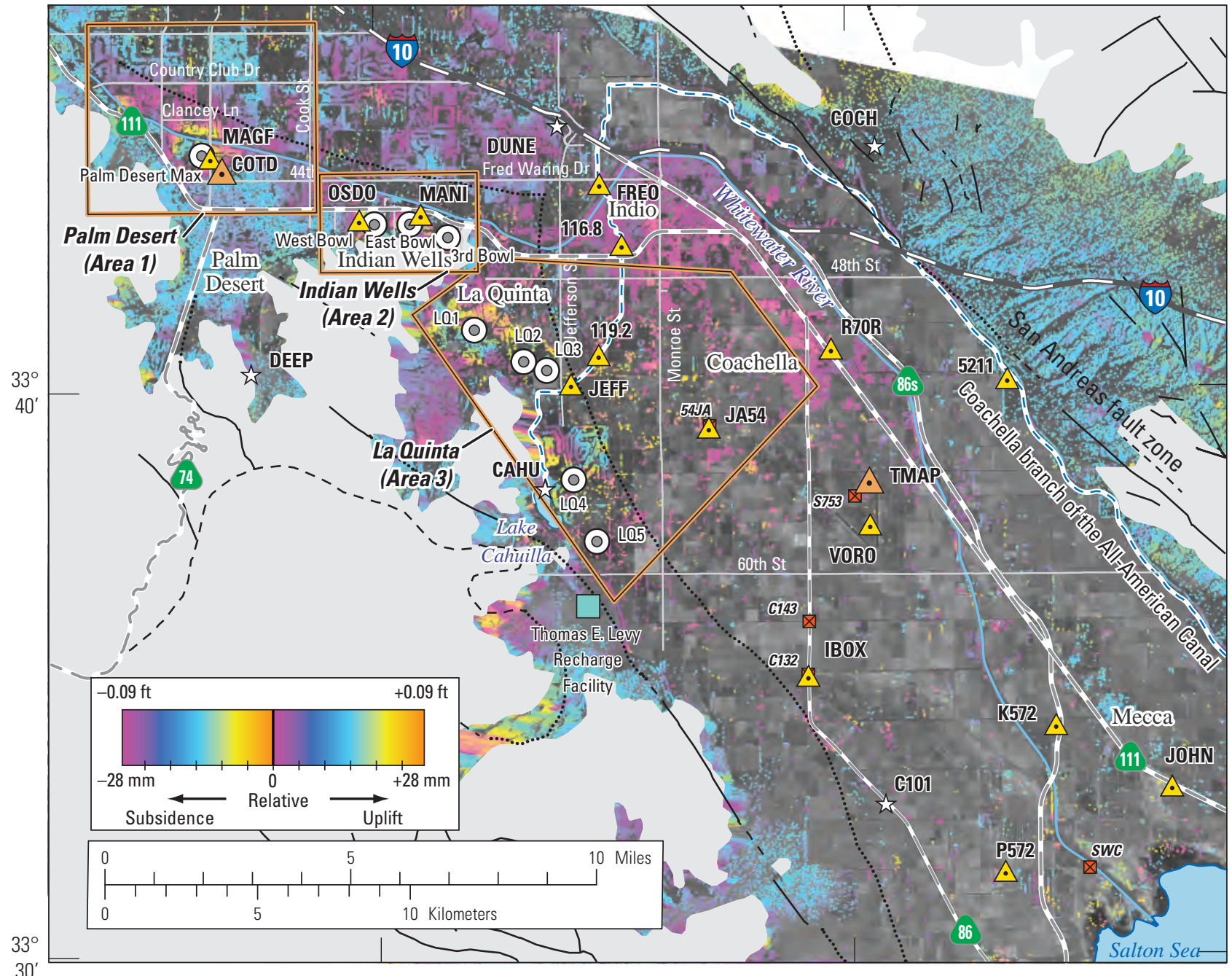

EXPLANATION

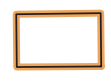

Subsidence area

Consolidated rock or partly consolidated deposits

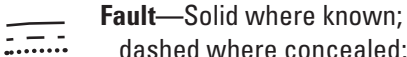
dotted where inferred

\begin{tabular}{|c|c|}
\hline & Geodetic monuments- \\
\hline . & Global Positioning System (GPS) station and identifier \\
\hline swc $\otimes$ & Destroyed or abandoned GPS station and identifier \\
\hline DUNE & $\begin{array}{l}\text { GPS control station for one or more of } \\
\text { the GPS surveys and identifier }\end{array}$ \\
\hline COTD & $\begin{array}{l}\text { Continuous Global Positioning System (CGPS) } \\
\text { station and identifier }\end{array}$ \\
\hline & $\begin{array}{l}\text { Locations of time-series interpretations } \\
\text { and identifier }\end{array}$ \\
\hline
\end{tabular}

Figure A6. PS InSAR interferogram for Coachella Valley, California: January 28, 1998-January 13, 1999. 


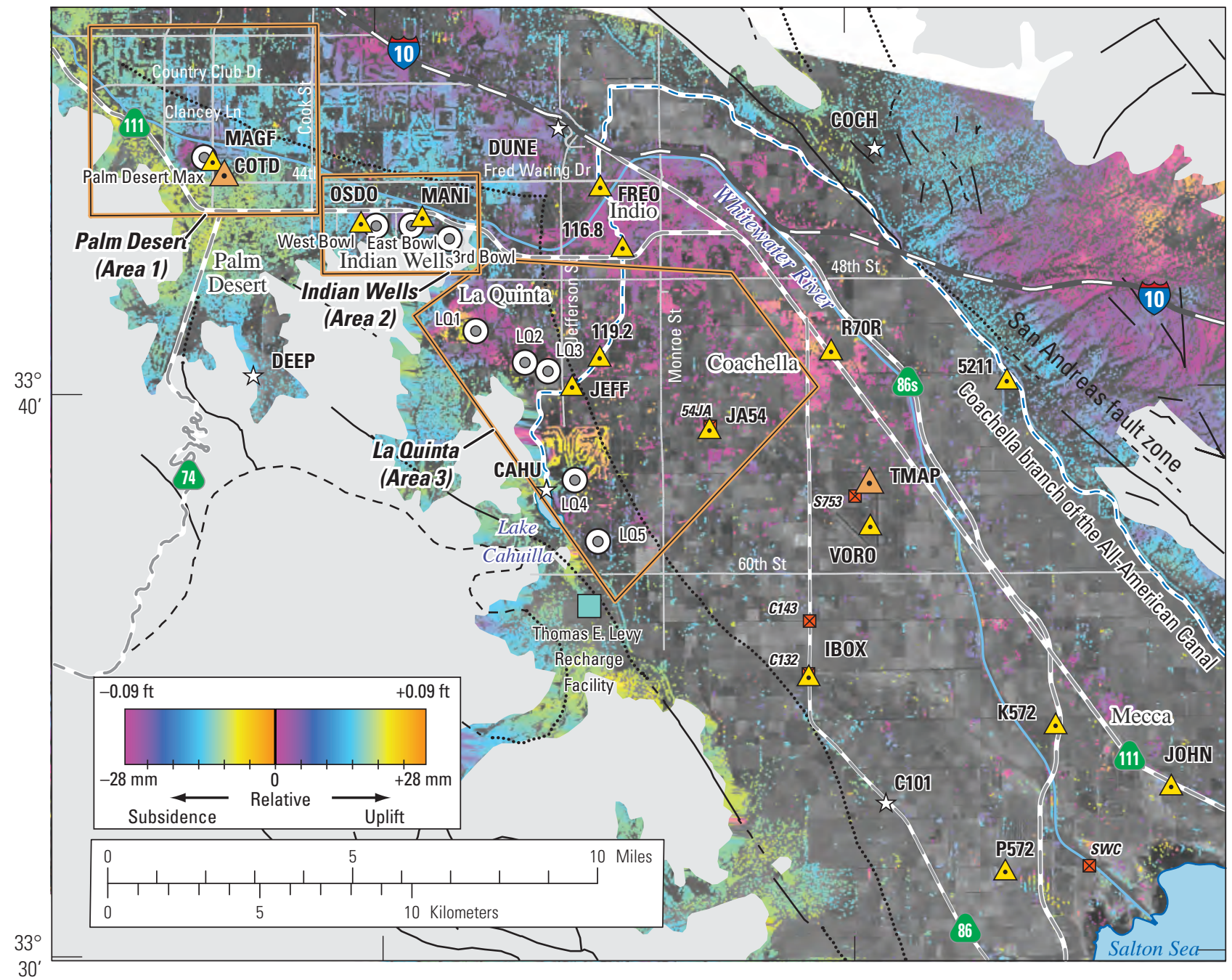

\section{EXPLANATION}

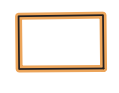

Subsidence area

Consolidated rock or partly consolidated deposits

___ Fault-Solid where known; dotted where inferred

FREO Geodetic monuments-
SWC Global Positioning System (GPS) station and identifier
DUNE Destroyed or abandoned GPS station and identifier
COTD $\begin{gathered}\text { GPS control station for one or more of } \\ \text { the GPS surveys and identifier }\end{gathered}$
LO2 Continuous Global Positioning System (CGPS)
station and identifier
Locations of time-series interpretations
and identifier

Figure A7. PS InSAR interferogram for Coachella Valley, California: February 17-August 11, 1999. 


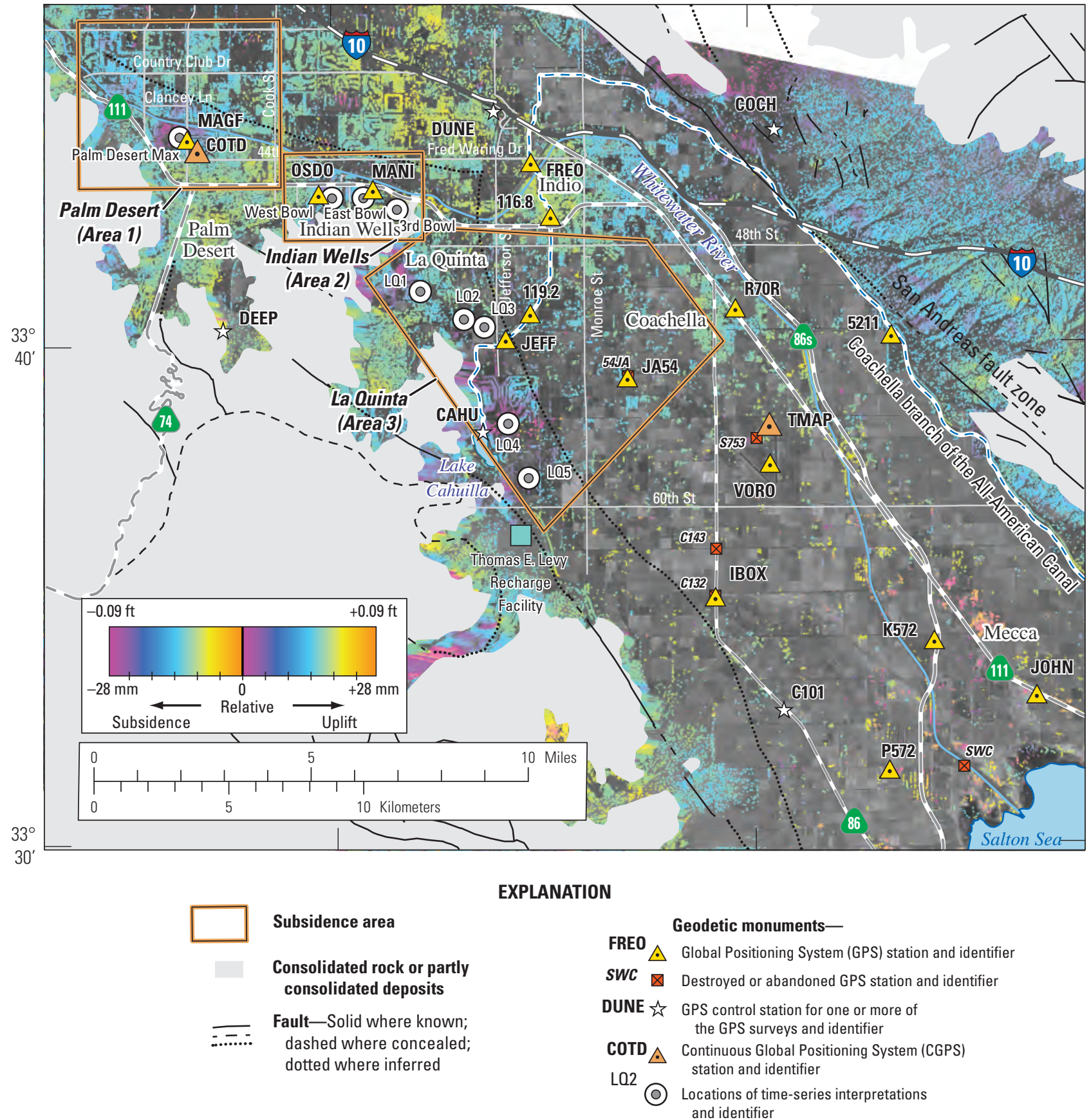

Figure A8. PS InSAR interferogram for Coachella Valley, California: November 24, 1999-April 12, 2000. 


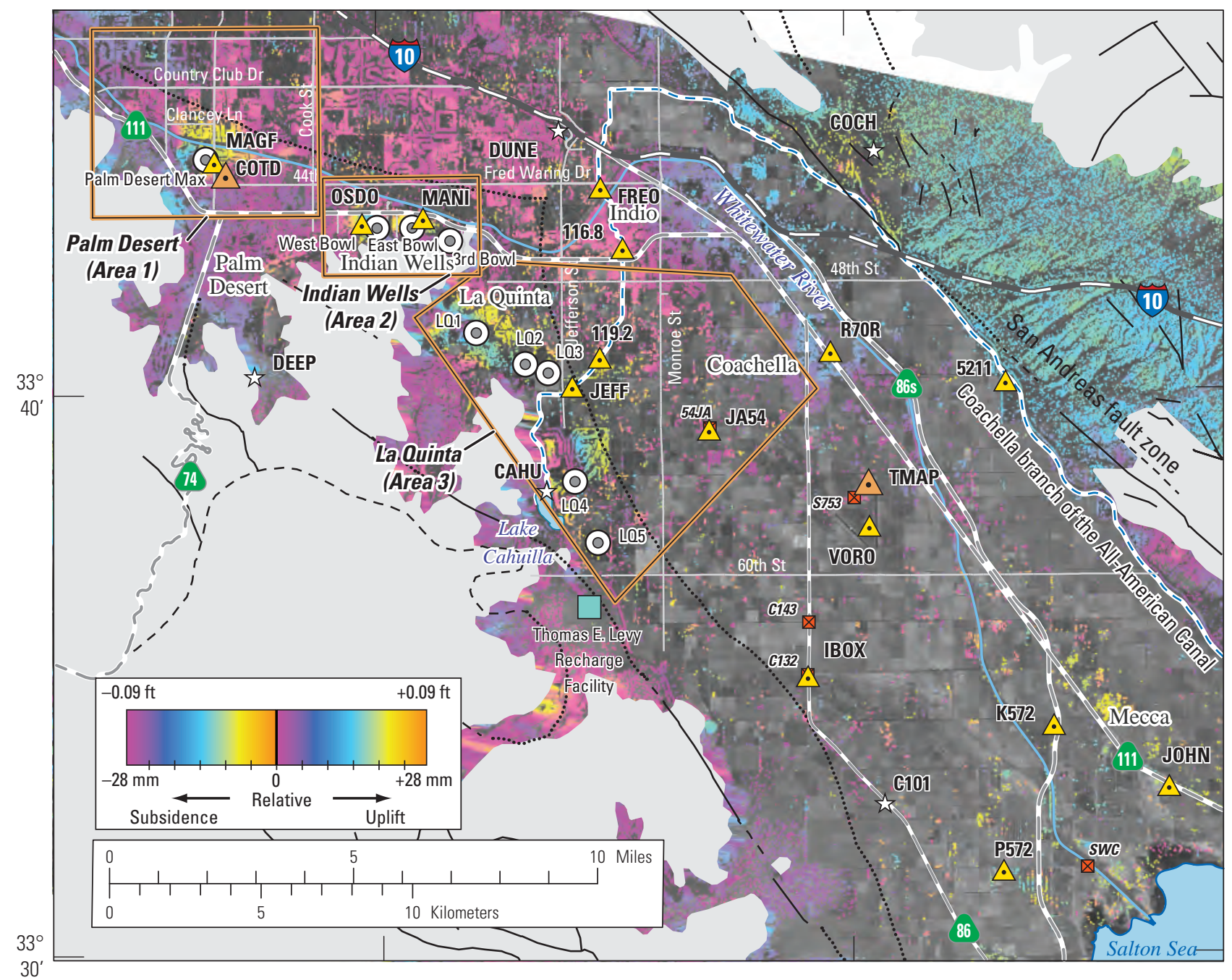

\section{EXPLANATION}

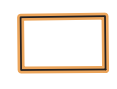

Subsidence area

Consolidated rock or partly consolidated deposits

$\overline{-}$-.... Fault-Solid where known; dotted where inferred

\author{
Geodetic monuments- \\ FREO $\triangle$ Global Positioning System (GPS) station and identifier \\ SWC $\square$ Destroyed or abandoned GPS station and identifier \\ DUNE $\downarrow$ tr GPS control station for one or more of \\ the GPS surveys and identifier \\ COTD A Continuous Global Positioning System (CGPS) \\ LQ2 \\ (2) Locations of time-series interpretations \\ and identifier
}

Figure A9. PS InSAR interferogram for Coachella Valley, California: April 12-November 8, 2000. 




Figure A10. PS InSAR interferogram for Coachella Valley, California: November 30, 2003-January 23, 2005. 
$116^{\circ} 20^{\prime}$ $116^{\circ} 10^{\prime}$

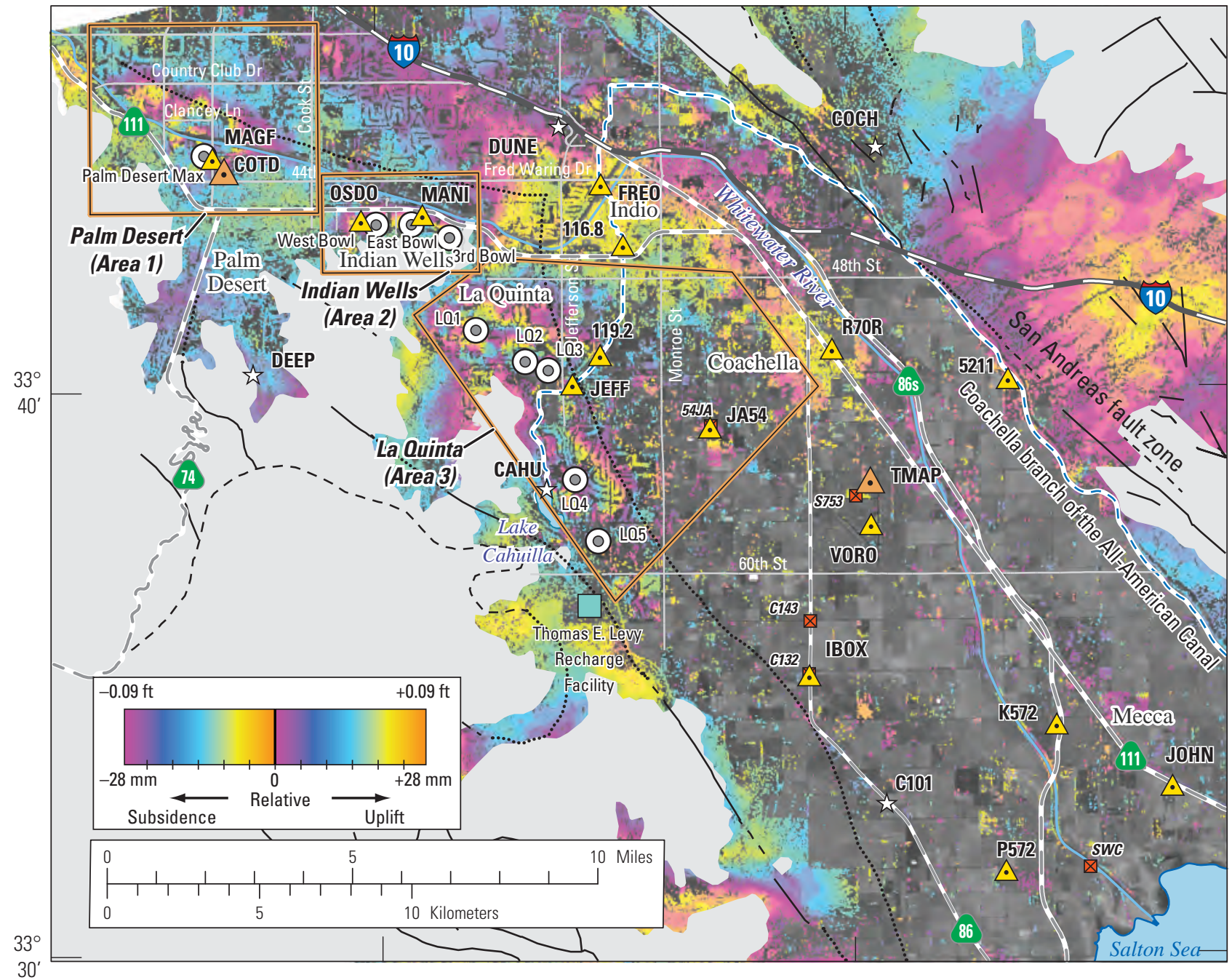

EXPLANATION

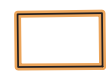

Subsidence area

Consolidated rock or partly consolidated deposits

$\overline{-\ldots . . .} \quad$ Fault-Solid where known; dotted where inferred

FREO Geodetic monuments-
SWC $\begin{gathered}\text { Global Positioning System (GPS) station and identifier } \\ \text { Destroyed or abandoned GPS station and identifier }\end{gathered}$
DUNE trs control station for one or more of
GOTD
the GPS surveys and identifier
LO2 Continuous Global Positioning System (CGPS)
station and identifier
Locations of time-series interpretations
and identifier

Figure A11. PS InSAR interferogram for Coachella Valley, California: February 27, 2005-May 28, 2006. 


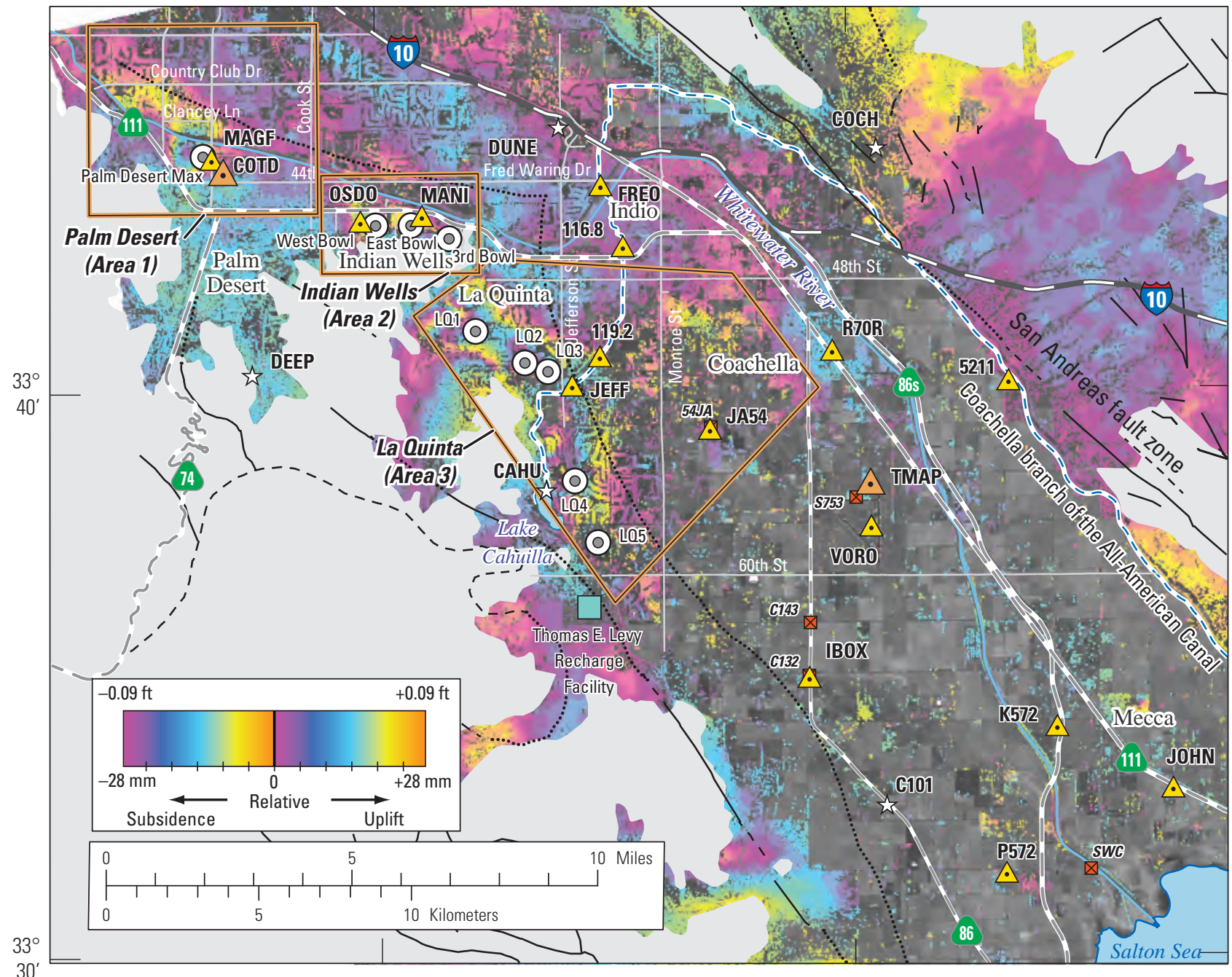

\section{EXPLANATION}

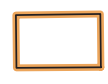

Subsidence area

Consolidated rock or partly consolidated deposits

- $\quad$ Fault-Solid where known; dotted where inferred

\begin{tabular}{|c|c|}
\hline & Geodetic monuments- \\
\hline${ }^{F R E O}{ }_{\triangle}$ & Global Positioning System (GPS) station and identifie \\
\hline SWC $\otimes$ & Destroyed or abandoned GPS station and identifier \\
\hline DUNE & $\begin{array}{l}\text { GPS control station for one or more of } \\
\text { the GPS surveys and identifier }\end{array}$ \\
\hline COTD & $\begin{array}{l}\text { Continuous Global Positioning System (CGPS) } \\
\text { station and identifier }\end{array}$ \\
\hline & $\begin{array}{l}\text { Locations of time-series interpretations } \\
\text { and identifier }\end{array}$ \\
\hline
\end{tabular}

Figure A12. PS InSAR interferogram for Coachella Valley, California: May 28-November 19, 2006. 


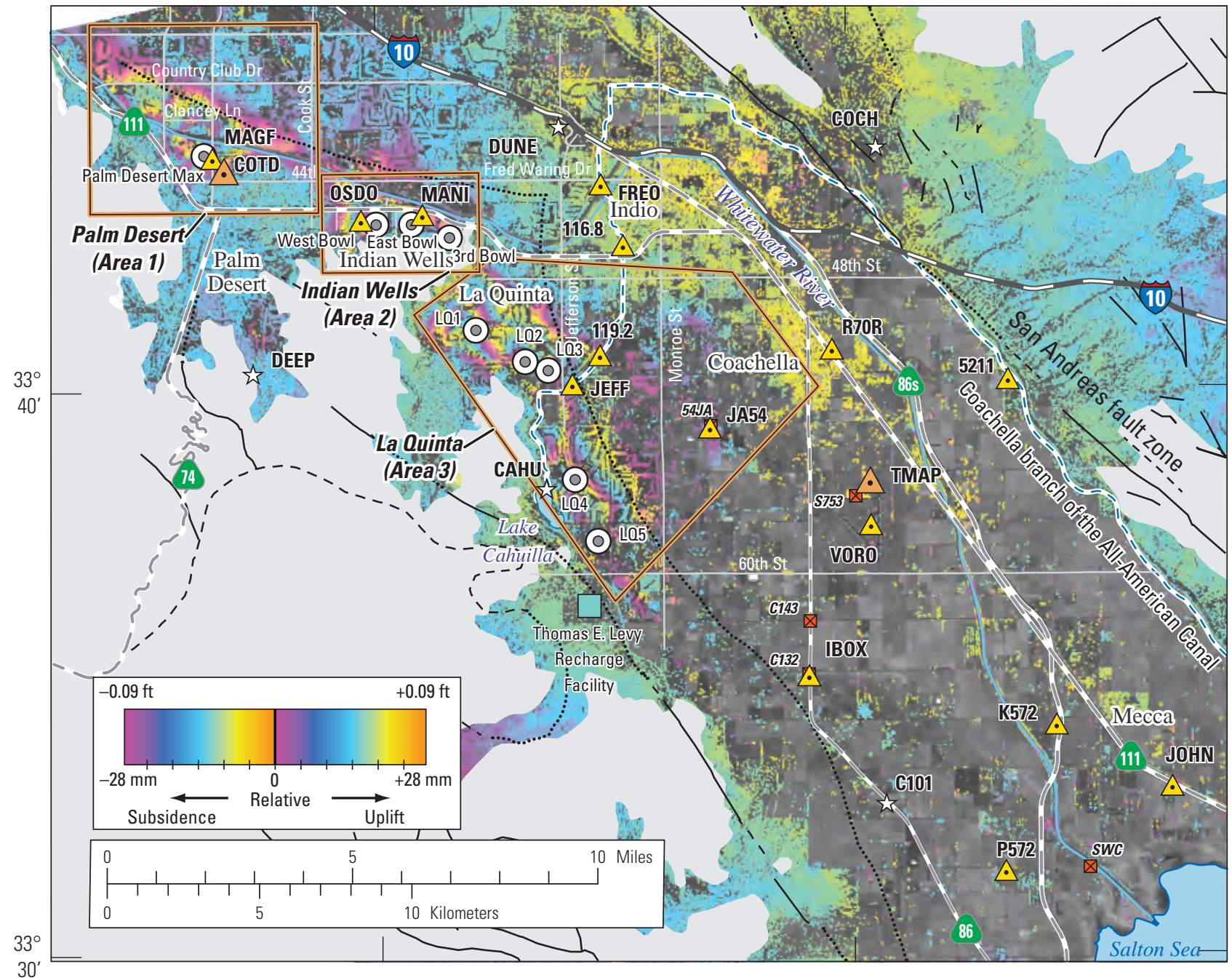

\section{EXPLANATION}

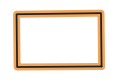

Subsidence area

Consolidated rock or partly consolidated deposits

Fault-......
dashed where concealed; dotted where inferred

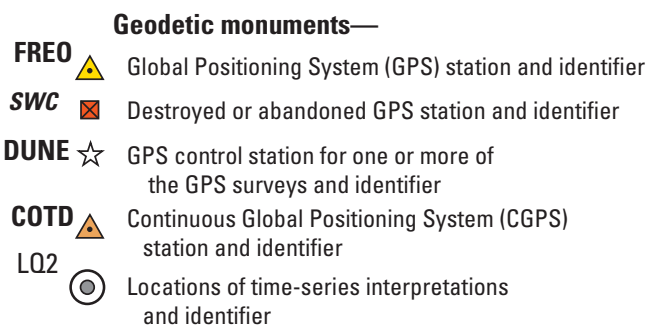

Figure A13. PS InSAR interferogram for Coachella Valley, California: December 24, 2006-March 23, 2008. 


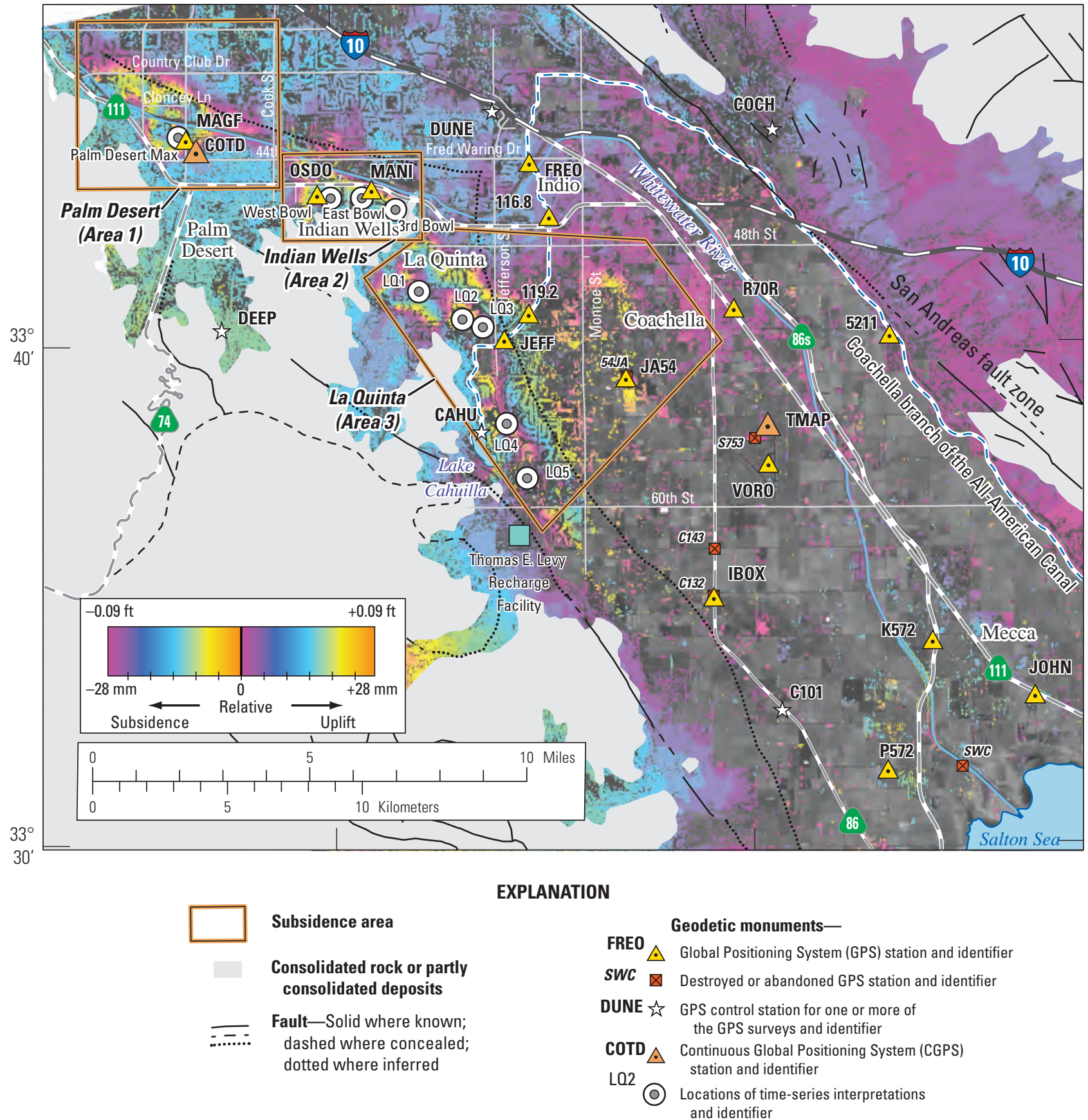

Figure A14. PS InSAR interferogram for Coachella Valley, California: March 23, 2008-March 8, 2009. 
$116^{\circ} 20^{\prime}$

$116^{\circ} 10^{\prime}$

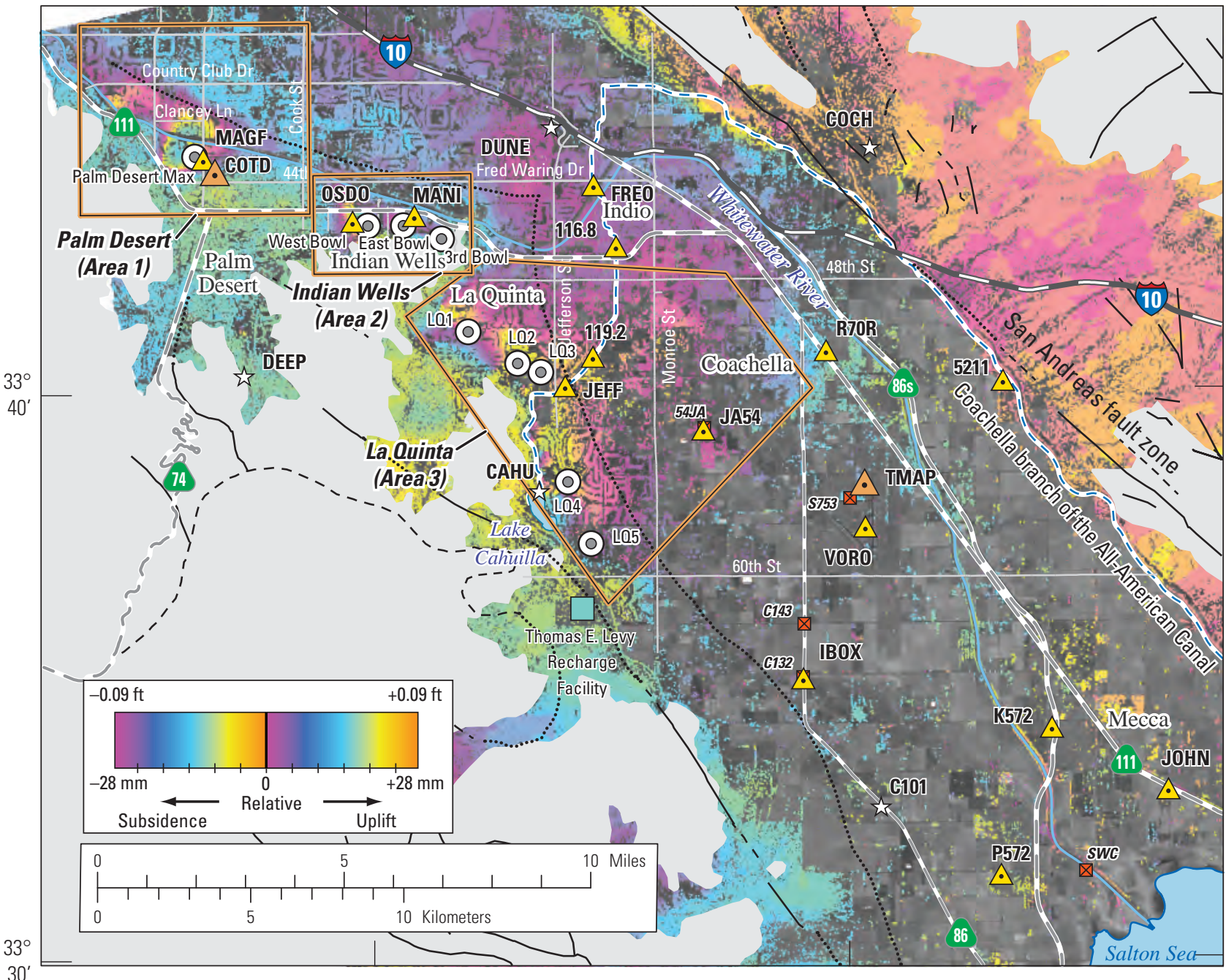

EXPLANATION

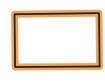

Subsidence area

Consolidated rock or partly consolidated deposits

$=\quad$ Fault-Solid where known; dotted where inferred

\begin{tabular}{|c|c|}
\hline & Geodetic monuments- \\
\hline${ }^{\text {FREO }} \triangle$ & Global Positioning System (GPS) station and identifier \\
\hline SWC 区 & Destroyed or abandoned GPS station and identifier \\
\hline DUNE & $\begin{array}{l}\text { GPS control station for one or more of } \\
\text { the GPS surveys and identifier }\end{array}$ \\
\hline COTD & $\begin{array}{l}\text { Continuous Global Positioning System (CGPS) } \\
\text { station and identifier }\end{array}$ \\
\hline & $\begin{array}{l}\text { Locations of time-series interpretations } \\
\text { and identifier }\end{array}$ \\
\hline
\end{tabular}

Figure A15. PS InSAR interferogram for Coachella Valley, California: March 8-August 30, 2009. 


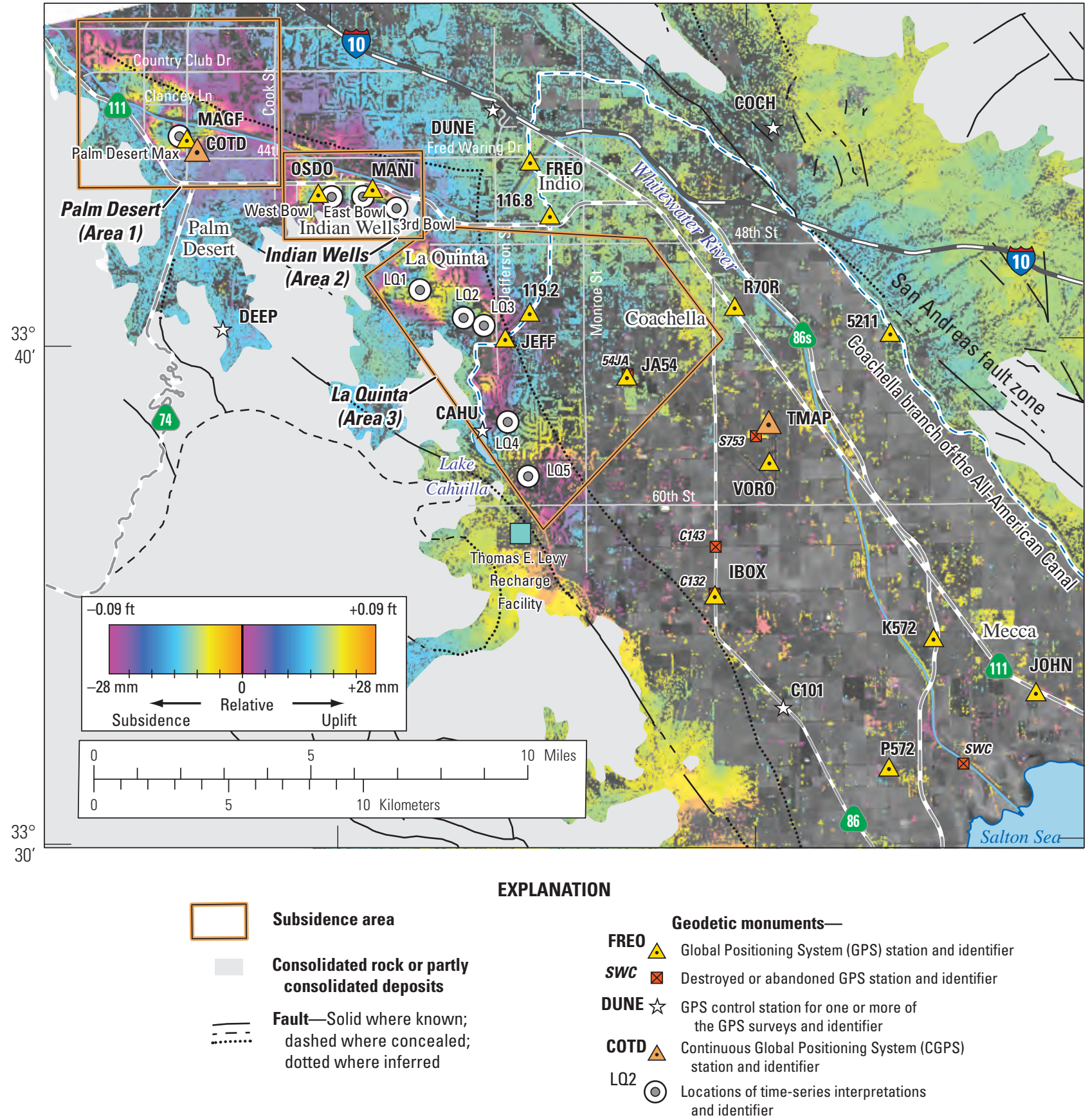

Figure A16. PS InSAR interferogram for Coachella Valley, California: August 30, 2009-September 19, 2010. 
Prepared by the Sacramento Publishing Service Center.

For more information concerning this report, contact:

Director

U.S. Geological Survey

California Water Science Center

6000 J Street, Placer Hall

Sacramento, CA 95819

dc_ca@usgs.gov

or visit our Web site at:

http://ca.water.usgs.gov 


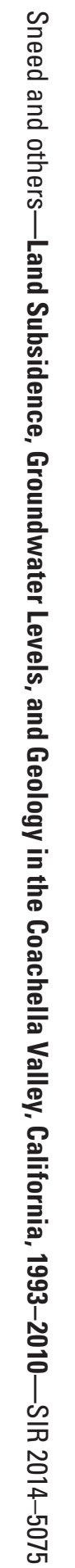

